Andrews University

Digital Commons @ Andrews University

1999

\title{
A Christian Approach to Traditional Male Circumcision Customs in Malawi
}

Harry Godfrey Mtike

Andrews University

Follow this and additional works at: https://digitalcommons.andrews.edu/dmin

Part of the Practical Theology Commons

\section{Recommended Citation}

Mtike, Harry Godfrey, "A Christian Approach to Traditional Male Circumcision Customs in Malawi" (1999).

Professional Dissertations DMin. 584.

https://dx.doi.org/10.32597/dmin/584

https://digitalcommons.andrews.edu/dmin/584

This Project Report is brought to you for free and open access by the Graduate Research at Digital Commons @ Andrews University. It has been accepted for inclusion in Professional Dissertations DMin by an authorized administrator of Digital Commons @ Andrews University. For more information, please contact repository@andrews.edu. 


\begin{abstract}
A CHRISTIAN APPROACH TO TRADITIONAL MALE CIRCUMCISION CUSTOMS IN MALAWI
\end{abstract}

by

Harry Godfrey Mtike

Adviser: Jon Dybdahl 


\title{
ABSTRACT OF GRADUATE STUDENT RESEARCH
}

Dissertation

\author{
Andrews University
}

Seventh-day Adventist Theological Seminary

\section{Title: A CHRISTIAN APPROACH TO TRADITIONAL MALE CIRCUMCISION CUSTOMS IN MALAWI}

Name of researcher: Harry Godfrey Mtike

Name and degree of faculty adviser: Jon Dybdahl, Ph.D.

Date completed: May 1999

\section{Problem}

The Lomwe and Yao tribes in Malawi practice traditional male circumcision rituals which are damaging the Malawian society. While these rituals have value and fill key functions in society, they are at the same time troublesome. The lack of proper medical equipment and training in performing actual circumcision, as well as accompanying teachings which encourage sexual promiscuity, makes these ceremonies physically, spiritually, and morally dangerous. The AIDS epidemic in Malawi can also be partly traced to these rituals. This study seeks to find a Christian answer which preserves the value of these practices while avoiding the problems connected with them. 


\section{Discussion}

The circumcision rituals and beliefs of the Lomwe and Yao tribes are described. Based on personal interviews of people who have been directly involved with the circumcisions, this dissertation details the activities which take place before, during, and after the circumcision, along with the teachings which are passed on to the circumcision initiates during the ceremony. In order to provide a comparative basis, the Old Testament and New Testament circumcision practices and teachings are also described. The relationship of biblical circumcision to the Old and New Covenants between God and His people is especially emphasized.

Through a contrast of the Malawian and Jewish circumcision rituals, this study highlights the dangers which traditional Lomwe and Yao circumcisions pose to the social and spiritual structures in Malawi. The current Malawian trends in AIDS, physiological injuries, and moral decline indicate that, unless the circumcision issues are addressed, the social and cultural conditions in Malawi will only continue to worsen.

\section{Recommendations}

The SDA church must allow and encourage the Lomwe and Yao people to address the dangers of circumcision in an culturally sensitive manner which preserves their heritage while avoiding physical dangers and moral decline. This study presents a six-step process of change which will enable the SDA church and the Malawian people to cooperatively explore options and make plans for dealing with the dangerous aspects of the circumcision rituals and teachings. This study concludes with a series of recommendations through which the SDA church could encourage its leaders and 
members, the Lomwe and Yao communities, and the Malawian government to cooperatively equip the Malawian people with the information and skills they need to improve and preserve their society. Possible substitution practices are also suggested. 
Andrews University

Seventh-day Adventist Theological Seminary

\title{
A CHRISTIAN APPROACH TO TRADITIONAL MALE CIRCUMCISION CUSTOMS IN MALAWI
}

\author{
A Dissertation \\ Presented in Partial Fulfillment \\ of the Requirements for the Degree \\ Doctor of Ministry
}

by

Harry Godfrey Mtike

May 1999 



\title{
A CHRISTIAN APPROACH TO TRADITIONAL MALE CIRCUMCISION CUSTOMS IN MALAWI
}

\author{
A dissertation \\ presented in partial fulfillment \\ of the requirements for the degree \\ Doctor of Ministry
}

by

Harry Godfrey Mtike

APPROVAL BY THE COMMITTEE:

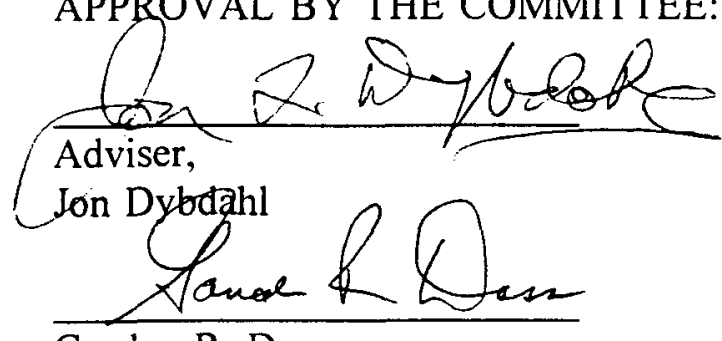

Gorden R. Doss

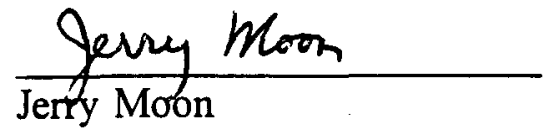

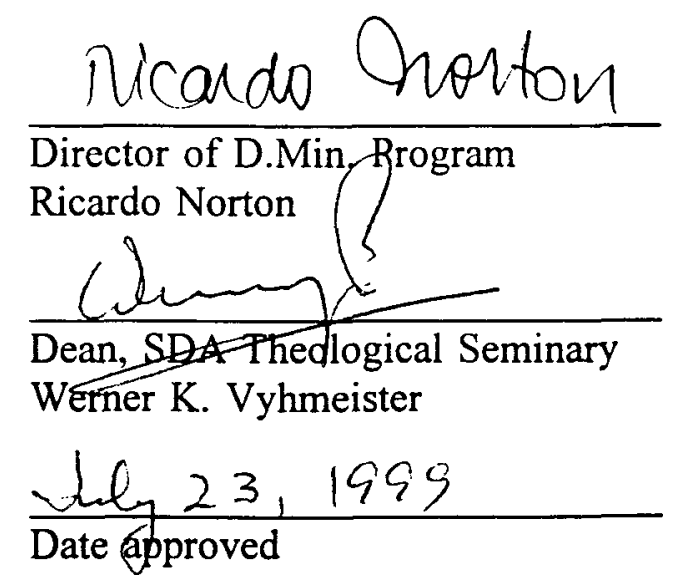




\section{TABLE OF CONTENTS}

ACKNOWLEDGMENTS $\ldots \ldots \ldots \ldots \ldots \ldots \ldots \ldots \ldots$ vii

\section{Chapter}

1. INTRODUCTION $\ldots \ldots \ldots \ldots \ldots \ldots \ldots \ldots \ldots \ldots \ldots \ldots \ldots \ldots$

Statement of the Problem $\ldots \ldots \ldots \ldots \ldots \ldots \ldots \ldots$

Purpose ........................... 3

Justification and Significance $\ldots \ldots \ldots \ldots \ldots \ldots$

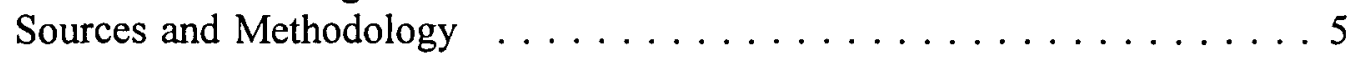

Structure and Outline .................... 5

2. A BRIEF SURVEY OF MALAWI $\ldots \ldots \ldots \ldots \ldots \ldots \ldots \ldots \ldots$

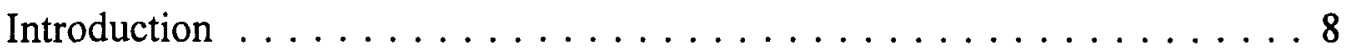

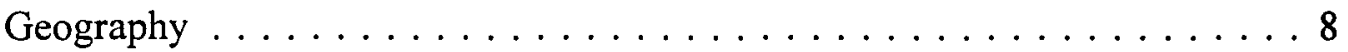

Historical Background $\ldots \ldots \ldots \ldots \ldots \ldots \ldots \ldots \ldots \ldots \ldots \ldots \ldots$

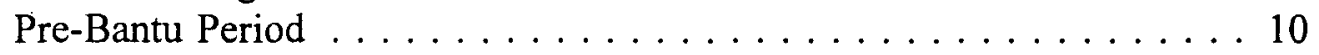

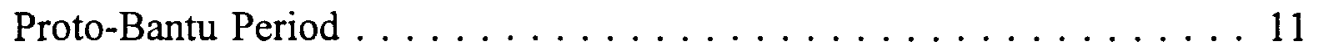

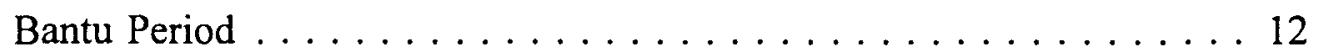

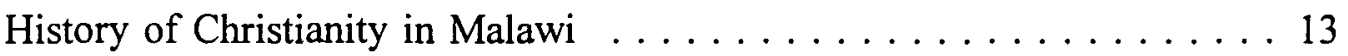

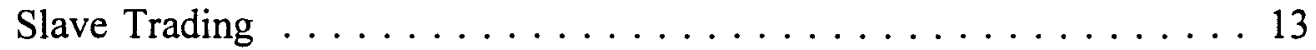

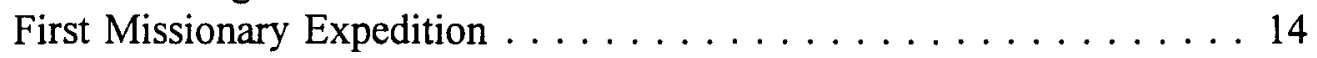

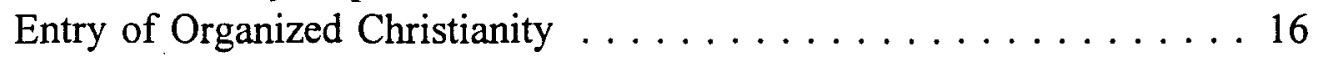

Anglican Church (UMCA) . . . . . . . . . . . . . 17

United Free Church of Scotland (Livingstonia Mission) . . . . 19

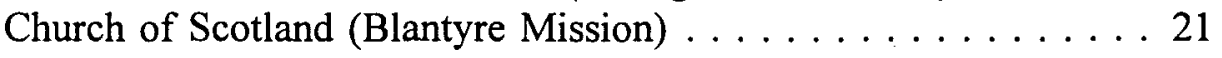

Dutch Reformed Church . . . . . . . . . . . . . 23

Roman Catholic Church . . . . . . . . . . . . . . 24

Islam . . . . . . . . . . . . . . . . . . . . . . 27

Seventh Day Baptist Church . . . . . . . . . . . 28

Seventh-day Adventist Church . . . . . . . . . . . . 29

Independence from Organized Christianity $\ldots \ldots \ldots \ldots \ldots \ldots \ldots 32$

Providence Industrial Mission . . . . . . . . . . . . 33

Watch Tower Movement . . . . . . . . . . . . . . 35

Other Independent Churches . . . . . . . . . . . . 35

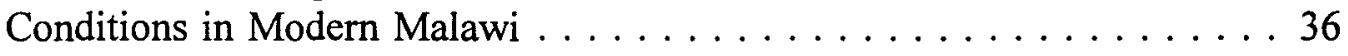


Major Tribes ...................... 36

Cultural Rituals ....................... 38

3. CIRCUMCISION RITUALS AND TEACHINGS OF THE LOMWE AND YAO TRIBES $\ldots \ldots \ldots \ldots \ldots \ldots \ldots \ldots \ldots$

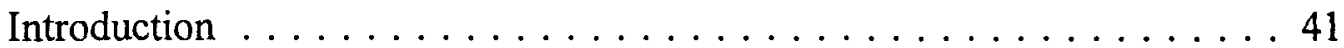

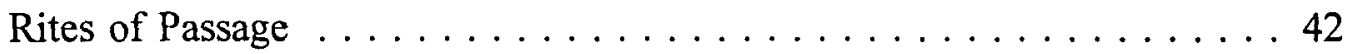

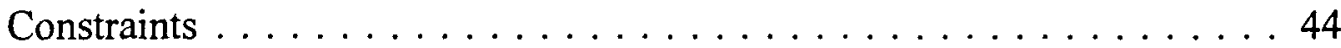

The Lomwe Tribe ...................... 47

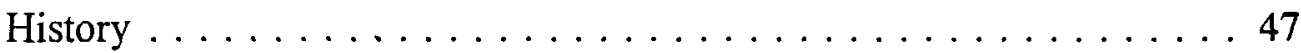

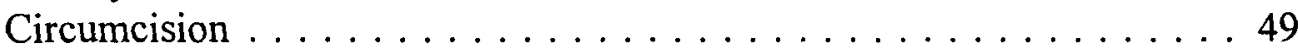

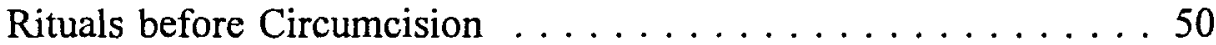

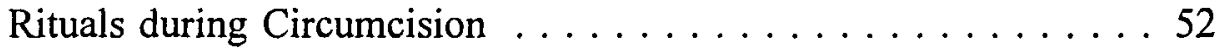

Rituals after Circumcision $\ldots \ldots \ldots \ldots \ldots \ldots \ldots 4$

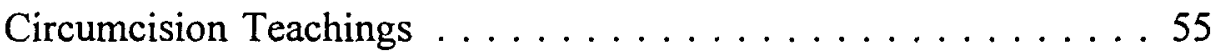

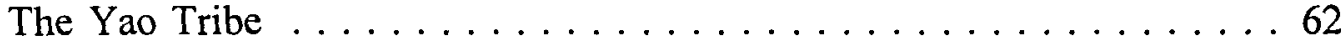

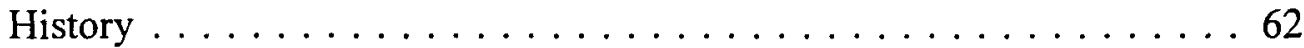

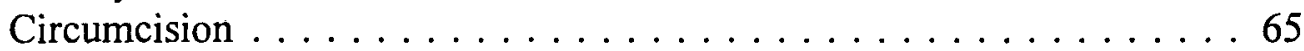

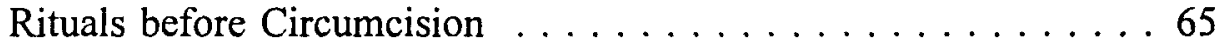

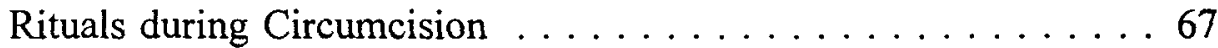

Rituals after Circumcision $\ldots \ldots \ldots \ldots \ldots \ldots 68 \ldots \ldots 6$

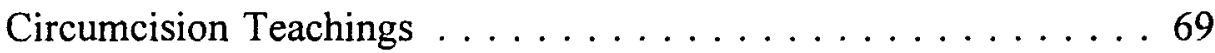

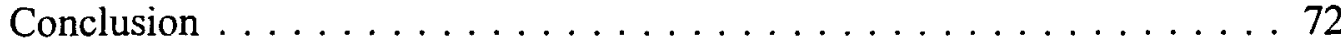

4. BIBLICAL CIRCUMCISION IN THE OLD AND NEW TESTAMENTS . 74

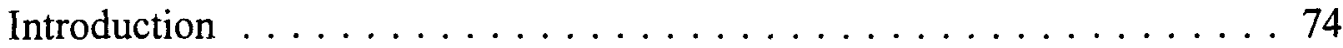

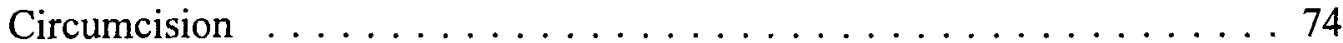

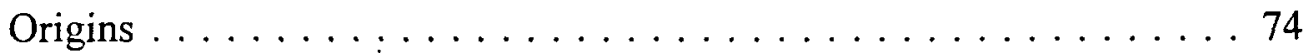

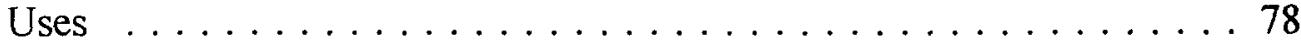

Circumcision in the Old Testament $\ldots \ldots \ldots \ldots \ldots \ldots \ldots \ldots$

Biblical Meaning and Origin $\ldots \ldots \ldots \ldots \ldots \ldots \ldots \ldots$

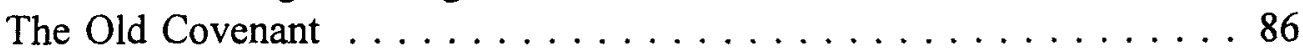

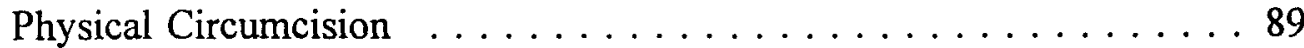

Jewish Circumcision Rituals $\ldots \ldots \ldots \ldots \ldots \ldots \ldots \ldots \ldots$

Time of Circumcision . . . . . . . . . . . . . 90

Rituals before Circumcision . . . . . . . . . . . 92

Rituals during Circumcision $\ldots \ldots \ldots \ldots \ldots \ldots . \ldots 94$

Rituals after Circumcision $\ldots \ldots \ldots \ldots \ldots \ldots . \ldots 96$

Circumcision in the New Testament . . . . . . . . . . . . 97

The New Covenant . . . . . . . . . . . . . . . . 97

Spiritual Circumcision $\ldots \ldots \ldots \ldots \ldots \ldots \ldots \ldots \ldots \ldots$

Baptism ......................... 103 


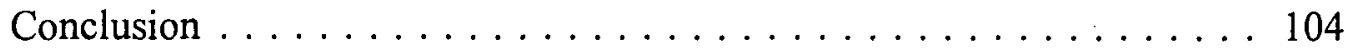

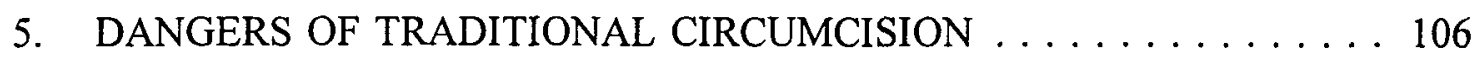

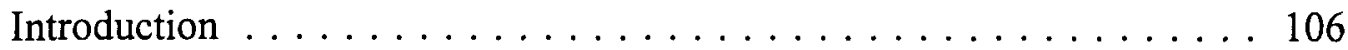

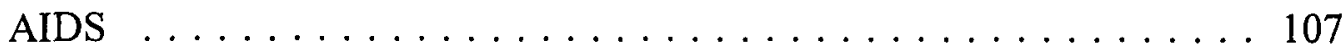

History . . . . . . . . . . . . . . . . . . . . 107

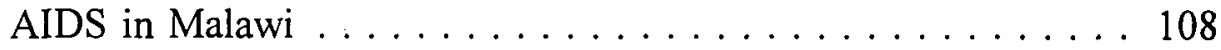

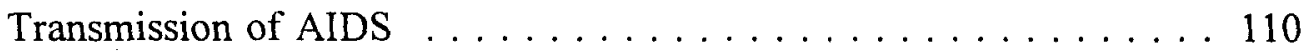

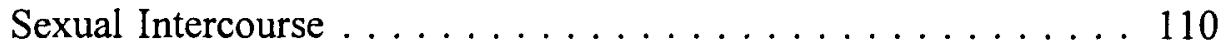

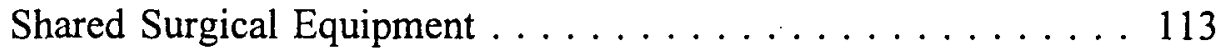

Physiological Damage .................... 115

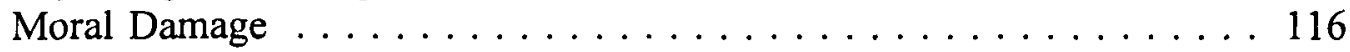

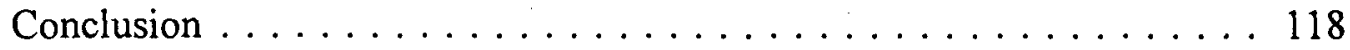

6. SUMMARY AND RECOMMENDATIONS $\ldots \ldots \ldots \ldots \ldots \ldots$

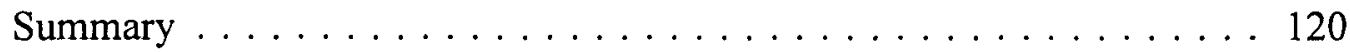

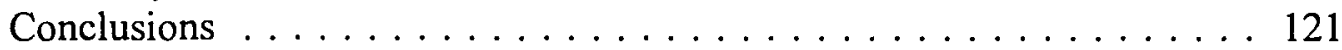

Cultural Improvement $\ldots \ldots \ldots \ldots \ldots \ldots \ldots \ldots \ldots \ldots \ldots \ldots \ldots$

Awareness . . . . . . . . . . . . . . . . . . . . 124

Interest . . . . . . . . . . . . . . . . . . . . 124

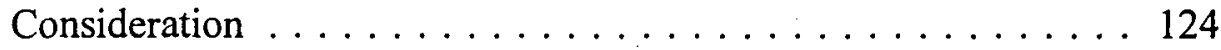

Choice ......................... 125

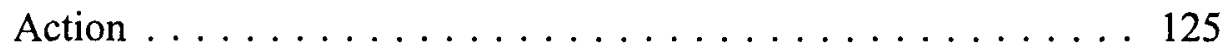

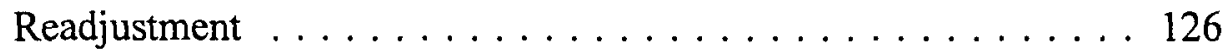

Recommendations ..................... 126

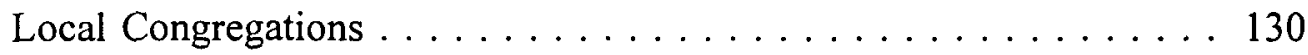

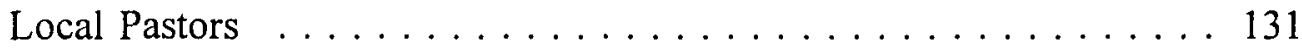

Field Leaders $\ldots \ldots \ldots \ldots \ldots \ldots \ldots \ldots \ldots \ldots \ldots$

Union Leaders . . . . . . . . . . . . . . . . . . . . . . . 135

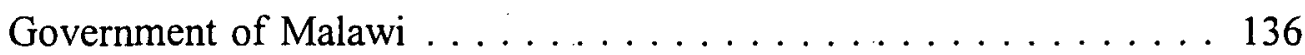

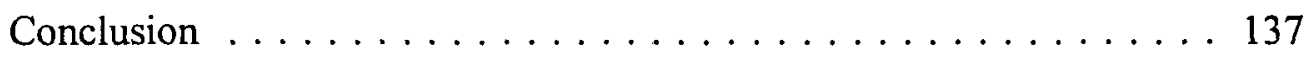

APPENDIX . . . . . . . . . . . . . . . . . . . . 139

BIBLIOGRAPHY . . . . . . . . . . . . . . . . . . . . . . . . . . . 142

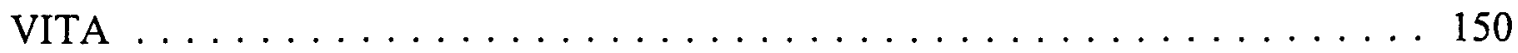




\section{ACKNOWLEDGMENTS}

I thank God for giving me hope, courage, and His loving care. Without Him, I would not have reached this academic goal. My most sincere gratitude goes to my dear wife, Rose, for her support and encouragement. I am deeply indebted to my two sons, Mike and Harry Jr., for understanding and supporting me even though I had to spend so much time apart from them while working on this project.

I give special recognition to: Dr. Jon Dybdahl, my dissertation chairman, for his advice and guidance; Dr. Gorden Doss, for graciously accepting my invitation to serve on my dissertation committee; Dr. Jerry Moon, for his careful and complete analysis and his insightful suggestions for improvement; and Dr. C. Mervyn Maxwell, for encouraging me to pursue my doctoral studies. 


\section{CHAPTER 1}

\section{INTRODUCTION}

\section{Statement of the Problem}

The Seventh-day Adventist church (SDA) in Malawi wrestles with tension between the traditional rituals of circumcision in Malawi and the biblical practice. Many Christians in Malawi still do not understand the biblical practice of circumcision. The traditional practice has exposed many young people to possible HIV infection and other medical problems. In some parts of Malawi the traditional practice of circumcision comes with many rituals which contradict biblical teachings. Behind this practice there is a belief that circumcision is a passage to manhood. The circumcised person is considered by the community to have reached the stage of maturity and is no longer treated as a child, regardless of his age.

When Christianity was introduced in Malawi by early missionaries, the local converts to Christianity were forbidden to practice some traditional customs, but they were not properly informed about why they should avoid these customs. Many Malawian Christians know that they do not need to fear ancestral spirits, but they continue to perform the traditional circumcision because of social pressure, not realizing the physical hazards which the traditional circumcision causes. The SDA church in Malawi, as well as all Malawians who practice traditional circumcision, need 
to be properly educated about its biological dangers. Furthermore, some Malawian Seventh-day Adventists feel that eradicating the traditional circumcision would remove their method of training their children to be obedient. These people feel that the circumcision practice should be encouraged despite the risks involved, such as transmission of HIV infection and severe physical injury.

Despite the church's efforts at spiritual education, it has been difficult for many Malawians to abandon the traditional practices because of their fear of "ancestral spirits." For example, there is a popular belief among the tribal communities that when a circumcised person becomes disobedient to his parents and elders of the community, it is because inadequate or improper instructions were given to him during the circumcision. The person's disobedience is thought to be caused by angry ancestral spirits. Many Malawians fear that violation of the rituals may anger the spirits of the ancestors, which may result in illness, death, and drought. Many Malawian SDAs who know that the rituals are non-biblical still participate in them out of fear of the ancestral spirits, hiding their actions from their fellow church members. Some Adventists also consult spiritual mediums to offer peace sacrifices to the ancestral spirits.

Even the Adventists who do not fear the ancestral spirits face a conflict. Some of the tribal communities expect every member of the community to practice all the tribal customs, and, as a result, the Seventh-day Adventists who live in these communities are looked upon as outcasts and rebels against the ancestral requirements. This cultural conflict has created tension between the traditional Malawian religious 
beliefs and Seventh-day Adventism. Some of the Malawian Adventists have attempted to resolve this conflict by viewing the traditional customs as a way of life and rejecting some of the beliefs introduced by the missionaries. These SDAs feel that the missionaries unfairly imposed their Western culture on the indigenous people and tried to eliminate Malawian cultural beliefs held for centuries before the coming of the missionaries.

\section{Purpose}

The purpose of this research was to study such practices and rituals of the contemporary Malawian society which affect Adventist faith, and the Malawian population affected by the terminal illness of HIV infection. The task of this research is to provide information that will equip pastors and laity in Malawi to understand the traditional circumcision rituals and replace them with biblical and medically safe practices.

This research provides recommendations to the Seventh-day Adventist church and the government of Malawi (through the Ministry of Health) so they may educate people about circumcision. This study is designed to address and answer three questions which have made this study necessary: (1) What are the things involved in the practice of circumcision? (2) What is the biblical view of circumcision and rituals? and (3) What should the Seventh-day Adventist church members have to follow in order to understand the traditional practice of circumcision in the light of the Bible? 


\section{Justification and Significance}

The total population of Malawi as of 1998 is about 9,500,000 people. ${ }^{1}$ The annual church statistical report as of December 31, 1997, shows 205,502 baptized members of the Seventh-day Adventist church. Of this number, 131,870 baptized members are from the South Malawi Field, ${ }^{2}$ where the traditional circumcision is highly practiced.

The current ministerial training at Lake View Seminary in Malawi provides little instruction on traditional practice of circumcision and rituals practiced by so many people, including some members of the Seventh-day Adventist church, and other Christian denominations as well. Although the Lake View Seminary has discussed circumcision and its effects on Malawian society during various family life and leadership seminars in the past few years, no seminars or other intensive studies have been made on this crucial cultural topic.

The Seventh-day Adventist church in Malawi has taught Christians about the traditional practices. The church for many years has taught Christians about circumcision during the camp meetings, Union and Field Sessions. Despite these efforts it has been difficult for Christians to abandon these practices because the fear of provoking the ancestral spirits is still rooted in the minds of both Christians and non-Christians alike.

\footnotetext{
'Seventh-day Adventist Yearbook (Washington, DC: Review and Herald Pub. Assn., 1998) 72.

${ }^{2}$ Charles L. Wingolo, Union Treasurer, Malawi Union of the Seventh-day Adventist Church, telephone interview by author, Harry G. Mtike, 30 August 1998.
} 
Many Christians who consult spiritual mediums by offering sacrifices believe that the church has failed to come up with the answer in matters of obedience to parents and elders of the society.

\section{Sources and Methodology}

This dissertation is an anthropological, biblical, and missiological study. As an anthropological study the information is based on the author's personal observations as a Malawian, born and raised within that context, and in one of the two tribes in which the traditional circumcision is practiced:

The sources for this study were drawn from available literature, journals, magazines, and other published literature on the topic. Additional information is also drawn from dissertations written on socio-cultural issues in Africa. Bible texts are used to guide this study and to provide an understanding of Old Testament circumcision among the Jews. Surveys conducted through questionnaires given to selected pastors and laity in Malawi, along with interviews of people from Malawi and other countries that practice traditional circumcision, provide insights into the current situation surrounding the traditional circumcision in Malawi.

\section{$\underline{\text { Structure and Outline }}$}

This study is divided into six chapters. Following the introduction in chapter 1, chapter 2 provides a general description of Malawi, focusing on the histories of Christianity and the major tribes in Malawi. 
Chapter 3 specifically examines the history and traditional circumcision rituals and teachings of the Lomwe and Yao tribes and gives a brief introduction of the Lomwe and Yao tribes and their beliefs.

Chapter 4 discusses the biblical understanding of circumcision in the Old and New Testament period. After using OT passages to determine the origin of circumcision, this chapter looks at the relationship between the Old Covenant and physical circumcision, including a description of the Jewish rituals. This ends with an examination of the NT teachings of the New Covenant, spiritual circumcision, and baptism.

Chapter 5 presents the physical and moral dangers of traditional circumcision by comparing the Malawian and Jewish circumcision rituals. These dangers include (1) the transmission of HIV infection by the use of unsterilized razor blades, (2) the encouragement of promiscuity at an early age, (3) death resulting from unskilled surgery, and (4) spiritual and ethical implications.

Chapter 6 summarizes the conclusions of this dissertation and uses these conclusions to provide recommendations to the SDA church members and leaders and the Government of Malawi. These recommendations include a contextualized model for a Christian approach to traditional circumcision which will not affect the Malawian society. This contextualized model uses the conclusions to analyze the Malawian rituals and practices and to formulate principles that will give answers to the unresolved social issues that affect Christian values and moral standards. This chapter also provides recommendations for educating the pastors and the laity and suggestions 
for increasing the government's participation in the church's efforts to curb the dangers of traditional circumcision in Malawi. 


\section{CHAPTER 2}

\section{A BRIEF SURVEY OF MALAWI}

\section{Introduction}

The practice of circumcision is very integral to the Lomwe and Yao tribes in the Malawian culture. In order for one to properly understand the scope of issues which surround the circumcision rituals in Malawi, the geography and history of the country must be taken into account. This chapter provides a brief and concise introduction to the land and people of Malawi, including an examination of the Christian groups which have entered Malawi and affected its culture.

\section{Geography}

Malawi, formerly known as Nyasaland, is a land of many contrasts. Located in East-Central Africa, Malawi shares political boundaries with Zambia to the West, Mozambique to the East, South, and West, and Tanzania to the North. ${ }^{1}$

The country of Malawi has various physical features. Moss and Willson give a brief description of the country's physical features:

Lying in the Great Rift Valley, Malawi's chief feature is Lake Malawi, 1,500 feet above sea level and 360 miles long. The land of Malawi lies west and south of this great lake and rises to a plateau 3,000 to 4,000 feet high, dotted

'National Geographical Atlas of the World (1990), s.v. "Malawi." 
with 8,000 to 10,000 -foot mountain peaks and sloping downward to the south. Mild temperatures and drizzly rains make the area ideal for agriculture. About one quarter of the land is forest, where pulpwood is harvested, and there is a wide variety of wildlife.

However, because of the difference of elevation in some parts of the country, there are variations in temperature and the annual rainfall. Like in a warm tropical climate, there are wet and dry seasons, and the vegetation varies from one place to another because of the variations in elevation. The large area in the north is covered by savanna, while some places in the Shire Valley are covered by thorn bushes. The uncontrolled cutting down of trees by the people in preparation for fields to plant crops and the indiscriminate use of trees for firewood have resulted in widespread deforestation in some parts of the country. Duff points out that "the perpetual cutting and burning of timber, by which the natives prepare the ground for crops, have operated powerfully to bring about this [poor] state of things."

\section{$\underline{\text { Historical Background }}$}

The history of Malawi provides the background for the Christian mission and its relation to the traditional customs and practices. The history of every country has an impact on the lives of the people and their attitudes, and this pattern holds true for the country of Malawi.

${ }^{1}$ Joyce Moss and George Willson, People of the World: Africans South of Sahara (Detroit: Gale Research International, 1991), 362.

${ }^{2}$ H. L. Duff, Nyasaland Under the Foreign Office (New York: Negro Universities Press, 1969), 74. 
The original Malawian people were prehistoric Bushmen-like people whose legacy is traced in a few rock paintings, the meanings of which are unknown. These tribes were displaced and absorbed by three different groups of people which migrated into Malawi and who were the ancestors of the modern Malawian people. Malawi was inhabited by three different civilizations which immigrated to Malawi during certain time periods: the Pre-Bantu, Proto-Bantu, and the Bantu periods. Each civilization during these time periods had different physical appearances, languages, and foodproduction methods. ${ }^{1}$ A brief examination of the periods of Malawian history which led to the present inhabitants of the country provides a better understanding of the modern-day Malawian culture, which is a major focus of this study on the Malawian cultural rituals of circumcision.

\section{Pre-Bantu Period}

The Pre-Bantu period dates back to the Stone Age, beginning in approximately 800 B.C. This period was discovered through the excavations of human remains in the Hora mountains, Fingira, Livingstonia plateau, Mikolongwe hills, and the Mpuzi mountains in the Dedza district. The excavations of human remains and the tools these humans used indicated the physical appearance of the people and the environment in which they lived. The discovery of stone tools was an indication that

\footnotetext{
'Bridglal Pachai, Malawi: The History of the Nation (London: Western Printing Services, 1973), 1.
} 
these people were hunters and lived in the forest. They also used bow and arrows made of stone with pointed heads. ${ }^{1}$

The Kafula and Batwa are known to have been the earliest Pre-Bantu people known to have migrated into Malawi. The Batwa people were of small stature, and later tribes nicknamed them accordingly, as Ransfold describes:

These aborigines of the Lake were very small and they were very sensitive about their size. The Bantu knew them as the Batwa but nicknamed them Amwandionera Kuti which means 'Where did you see me?' for that was the first question they put to any stranger. If they were given the prescribed assurance, 'I saw you from a long way off,' the pygmies would dance around shouting, 'I am a big man after all'; but any other answer was taken as a moral insult to be revenged with a poisoned arrow. ${ }^{2}$

The Kafulas and the Batwas were skilled hunters, dependent on vegetable food and natural fruit. They experienced frequent attacks by tribes which had occupied Malawi before the arrival of the Pre-Bantu tribes, and many were either killed or absorbed into later Proto-Bantu and Bantu tribes. The few Pre-Bantu people who survived during the attacks moved to their current location in Lundazi and along the Kafue River in Zambia, as well as in Southwest Africa and Botswana.

\section{Proto-Bantu Period}

During the Proto-Bantu period, other tribes came from the northern areas of Malawi and settled in the southern region of Malawi where the Kafula and Batwa had settled before. The Proto-Bantu tribes, the Katanga, Pule, and Lenda, were tall and

I'Ibid.

${ }^{2}$ Oliver Ransforld, Livingstone's Lake: The Drama of Nyasa, Afric's Inland Sea (New York: Thomas Y. Crowell Co., 1967), 15. 
well-built, unlike the diminutive Kafula and Batwa. The Kafula and Batwa were assimilated into these Proto-Bantu groups through intermarriage,' and Pachai points out that where this tribal absorption took place, the Proto-Bantu tribes gained additional workers.

\section{Bantu Period}

About A.D. 100 a third group of tribes migrated into the southern region. The Bantu-speaking people, known as Maravi, came from the different areas of the Congo Basin and moved into the west, south, and east parts of Lake Malawi. Pachai points out the three distinctive routes followed by the Maravi in entering Malawi: The southern route was from the Zambezi Valley northward through the Shire Valley, the western route embraced the passage from east of Congo, and the northern route was up to the northern region of Malawi. ${ }^{2}$ The Maravi people finally settled along the Shire River and in the western and southern part of Lake Malawi, stretching over into Zambia and Mozambique; the modern name of Malawi is derived from this people's name, Maravi. ${ }^{3}$ The Maravi were more prosperous and skilled than the neighboring tribes which occupied Malawi at the time; they had polished instruments, such as hoes

'Jaspine D.C. Bilima, "James Malinki of Malawi: Church Leader in CrossCultural Ministry" (D.Min dissertation, Andrews University, 1993), 14.

${ }^{2}$ Ibid., 5.

${ }^{3}$ Harold D. Nelson, Area Hand Book for Malawi (Washington, DC: American University Press, 1975), 11. 
and knives, and spears similar to those of the European settlers. ${ }^{1}$ The tribes of the Bantu migration united into a federation of various tribal groups, forming a number of tribes, including the Chewa, Nyanja, Chipeta, Nsenga, Chikunda (or Sena), Mbo, Ntumba, and Zimba tribes. ${ }^{2}$ The Bantu established their empire along the trade routes from West Africa to the Indian Ocean. However, due to the slave industry which came to Malawi with the Portuguese, the Bantu empire was later dispersed, and only four major tribes currently remain in Malawi: Chewa in the central region, Lomwe and Yao in the south, and Tumbuka in the north. ${ }^{3}$

\section{History of Christianity in Malawi}

Slave Trading

The Maravi federation lasted until 1616 when Gaspar Boccaro, a Portuguese explorer, inspired the Portuguese to establish trade routes through Malawi in search of gold and silver mines. This expedition made a great impact on the history of Malawi during the Middle Ages. ${ }^{4}$ These explorations also led to the establishment of a slave trade in the Maravi empire by the Portuguese to the east in Mozambique and the Arabs to the north.

'David T. Williams, Malawi: The Politics of Despair (London: Cornell University Press, 1978), 26.

${ }^{2}$ Pachai, Malawi, 6.

${ }^{3}$ Williams, 24.

${ }^{4}$ Ibid., 64. 
Two ethnic groups moved into Malawi around this time: the Yao from Mozambique, and the Ngoni, descendants of Chaka Zulu from South Africa. Originally, the Yao came to Malawi because of a drought in Mozambique, and the Ngoni fled to Malawi to escape the iron rule of Chaka Zulu, but these two tribes soon began working as slave agents for the Portuguese and Arabs. The indigenous people experienced frequent raids from the Yao and the Ngoni in search for slaves, as well as for cattle and wives.

The slaves were sold to the slave traders, the Arabs and the Portuguese, ${ }^{1}$ and this practice continued until the British took over Malawi as a British protectorate in 1891 . Ironically, the slave trade which took so many Malawians and other Africans from their homelands was also a main reason for the coming of Christianity to Africa. As the following section details, one of the major results of Christianity's entrance into Malawi was the abolishment of the slave trade.

\section{First Missionary Expedition}

In 1859, David Livingstone, a British missionary, became the first missionary to arrive in Malawi (or Nyasaland, as it was called at that time). Livingstone entered through the southern part of Malawi, crossing the Shire River and discovering Lake Chirwa in the same year. Livingstone's main desire was to introduce Christianity and commerce to the indigenous people of Malawi in an attempt to stop the slave trade,

'Ibid., 30-36. 
which was the main trade among the Arabs and Portuguese in that region. ${ }^{1}$ The Universities Mission of Central Africa (UMCA) was formed by the Anglican church after Livingstone returned to Great Britain from Nyasaland and appealed for the British to interfere with the slave trade in Malawi and encourage missionary work. In 1861, Livingstone, accompanied by Bishop Mackenzie, established a mission station in the Shire Valley which was later relocated to Zanzibar (see section on the Anglican church below). This mission effort failed when the UMCA withdrew its support because the people of Nyasaland did not provide any moral support for continuing the mission work.

In 1873, Livingstone died at Chitambo in Central Africa, ${ }^{2}$ and his body was taken from Lake Bangweolo in Northern Zambia, through the Indian Ocean, and later to England where he was buried at Westminister Abbey in London on the 18th of April, $1874 .^{3}$ Livingstone gave the last part of his life to Africa, and through his efforts, Christianity and commerce were introduced to Malawi and became obstacles to the slave trade. Because of Livingstone's lead, missionary work was developed and enhanced; after Livingstone's death, mission stations were established along the western shore of Lake Malawi and in the southern region of Malawi near Blantyre. The Christian missionaries not only built churches but also helped to unite the people of Nyasaland during times of tribal conflict. Livingstone's visit to Malawi paved the

\footnotetext{
'Pachai, Malawi, 71.

${ }^{2}$ Nelson, 20-21.

${ }^{3}$ Williams, 43.
} 
way for missionaries and traders, and because of his efforts, the British later colonized the country and made it a British protectorate, which eliminated the slave trade in Nyasaland.

\section{Entry of Organized Christianity}

The introduction of Christianity to the people of Africa by the European and American missionaries was influenced by the missionaries' attitudes toward the continent of Africa. The missionaries believed that God had entrusted them with the responsibility to raise African tribes from their heathen lives of brutality. The missionaries felt that the introduction of Christianity, education, new agricultural methods, and other important crafts could be the best ways of civilizing the Africans, replacing their indolence with hard work, deception with honesty, drunkenness with sobriety, and belief in superstition and traditional practices with the everlasting truths of the Gospel. ${ }^{1}$

These ideas were rooted in the minds of the leading missionaries, and all missionaries and laymen were exposed to these ideas during their preparation for mission service. The missionaries characterized the African people as primitive, uncivilized, and without destiny. On the other hand, the Africans perceived the missionaries as revolutionists attacking long-accepted African beliefs and attempting to transform the basic institutions of African society which had been established by their ancestors. One of the African customs which the Christian missionaries strove to

\footnotetext{
'Robin Hallett, Africa to 1875: A Modern History (Ann Arbor, MI: University of Michigan Press, 1970), 372.
} 
abolish was the ritual of circumcision. As this study shows in chapter 3 , this custom holds great social and cultural importance for various African tribes, and the African converts often gave up circumcision without genuinely believing that it was wrong.

The opposing goals of the Western missionaries and the African indigenous people raised conflicts between traditional beliefs and Christianity which have continued until the present and are discussed in this study. This section presents a brief history of a few selected religious organizations which have attempted to bring Christianity to the people of Malawi in order to provide a historical context for the conflict surrounding the circumcision rituals of the Lomwe and Yao which is addressed in this study.

\section{Anglican Church (UMCA)}

The history of the Anglican church in Malawi traces its roots to 1861 when Charles Frederick Mackenzie was declared the first bishop of the Anglican Church in St. George Cathedral of Cape Town, South Africa. That same year, a number of Anglican missionaries sponsored by the UMCA of Great Britain and led by Bishop Mackenzie reached Kangore, the source of the Zambezi River. These missionaries were met by the British missionary, David Livingstone, who guided them to Shire Valley in the southern province of Malawi. The missionaries attempted to establish a mission station there, but the Shire Valley province proved to be an unsuitable place for missionary work; the limited supplies could not meet their needs, internal disputes 
broke out among the missionaries, and malaria eventually killed most of the missionaries. $^{1}$

Because of the unbearable conditions which affected these missionaries, the Anglican church leaders decided to move the mission to Magomero in the southern region of Malawi. The hostility of the indigenous people and invasions by slavers caused this place to also be unsuitable for missionaries. ${ }^{2}$ In 1862 , after the death of Bishop Mackenzie, William Tozer, the bishop's successor, decided to move the mission station because of the unfavorable circumstances which hindered the permanent establishment of the mission station, and in 1864 , the mission was moved to Zanzibar. $^{3}$

The year 1885 marked a turning point for the Anglican church in Malawi when Likoma Island in the northern region of Malawi was chosen to be the new location for the UMCA, due to its suitable condition and its freedom from the slave raiders. ${ }^{4}$ Likoma Island became the center of missionary operation for the Anglican Church in Malawi. In 1895, the first Anglican school in Malawi was opened, and Pachai points out that by 1889 , at least twenty-two Anglican stations had been established. ${ }^{5}$ In

'Norman H. Pollock, Jr., Nyasaland and Northern Rhodesia: Corridor to the North (Pittsburgh: Duquese University Press, 1971), 15.

${ }^{2}$ Bridglal Pachai, The Early History of Malawi (Chicago: Northwestern University Press, 1972), 346.

${ }^{3}$ Pollock, 15.

${ }^{4}$ Pachai, Early History, 350.

${ }^{5}$ Ibid. 
1971, the Anglican church was separated into two dioceses in Malawi: the Diocese of Lake Malawi and the Diocese of Southern Malawi. ${ }^{1}$

As the first Christian church to enter Malawi, the Anglican church held great influence in determining how the other churches would later approach and relate to the indigenous people of Malawi. Unfortunately, the Anglican missionaries did not attempt to allow for cultural differences between their European background and the African culture of their converts. By requiring their Malawian converts to give up their cultural heritage, including circumcision and the rites which accompanied it, the Anglican church set a precedent for the pattern of Christian missionary work which later Christian movements in Malawi would follow.

\section{United Free Church of Scotland (Livingstonia Mission)}

In 1859, Rev. Dr. James Stewart, a twenty-one-year-old student at New College in Edinburgh, developed the idea of a missionary expedition to places which were believed to have not been reached with the Gospel. ${ }^{2}$ In 1875, two medical doctors, Dr. Ed Young and Dr. Robert Laws, led a group of missionaries on the Ilala, the first steamer to sail on Lake Malawi. The missionaries first settled at Cape Maclear, the southern end of Lake Malawi, where they established a memorial mission named Livingstonia in memory of David Livingstone who had opened the way to Africa for

\footnotetext{
'David B. Barrett, "Malawi," World Christian Encyclopedia (Nairobi, Kenya: Oxford University Press, 1982), 471.

${ }^{2} \mathrm{John}$ McCracken, Politics and Christianity in Malawi, 1875-1940 (London: Cambridge University Press, 1977), 21.
} 
missionary activities. ${ }^{1}$ It was later discovered that Cape Maclear was unhealthful for missionary work, so in 1881 it was proposed to move the mission station to Bandawe, the land along the northern shore of Lake Malawi. This new site also proved unhealthful to the missionaries, and in 1894 the Livingstonia mission was moved to its current location in the Rumphi district. ${ }^{2}$

During the missionary expedition, Dr. Robert Laws made contacts with Mbelwa, the most famous chief of the kingdom of the Ngoni people. The contacts with the chief led to the establishment of the peaceful relations between the Ngoni people and the British missionaries. The Church's main goals were to preach the Gospel to the indigenous people and to provide them with new skills such as reading and writing, carpentry, agriculture, and black-smithing. It is recorded that by 1885 , the Church had established thirty-five schools and by the end of the decade, 2,000 pupils were attending these schools. ${ }^{3}$ By the end of 1920 , the mission had established 446 schools with an enrollment of 25,772 students and 853 teachers, and the mission collected school fees which amounted to $2229-19 \mathrm{~s}-4 \mathrm{~d}$, a very large amount of money at that time. The Livingstonia Mission had established 34 churches comprising the membership of $7,663 .^{4}$

'Nelson, 21.

${ }^{2}$ Stephen Murray, A Handbook of Nyasaland (London: Crown Agents, 1922), 239-240.

${ }^{3}$ Cynthia A. Crosby, Historical Dictionary of Malawi (Metuchen, NJ: Scarecrow Press, 1980), 84.

${ }^{4}$ Murray, 240. 
The Livingstonia Mission set a pattern for missionary work, education, industrialization, medicine, and evangelistic approach to the natives of Malawi which was later followed by missionaries of other denominations. However, the Livingstonia missionaries continued the pattern begun by the Anglican church by requiring their converts to adapt to the European style of living and culture, abandoning the Malawian heritage in exchange for salvation. In modern times, the United Free Church of Scotland in Malawi is spread in all of the districts, engaged in evangelical, educational, industrial, and medical labors.

Church of Scotland (Blantyre Mission)

In 1876 , the first mission station was established in Blantyre by Scottish missionaries, as a result of united efforts by the leader of the Church of Scotland at Cape Maclear and the Livingstonia Mission of the United Free Church of Scotland. The mission station was called Blantyre Mission after David Livingstone's birthplace in Scotland. ${ }^{1}$ The site was chosen by Henry Henderson, one of the founders of the Livingstonia Mission in 1875. The main objectives of Blantyre Mission were threefold: (1) to evangelize the people, (2) to provide medical care, and (3) to provide education to the local people. ${ }^{2}$

The mission was losing its effectiveness until Rev. David C. Scott became the leader of the Blantyre Mission in 1881. Scott, who was assisted by Rev. Alexander

${ }^{1}$ Crosby, 18.

${ }^{2}$ Murray, 240. 
Hetherwick, preferred working with African evangelists, and three of his African colleagues became deacons: Joseph Bismarck, Rondau Kaferanjira, and Donald Malota. Scott found little support among the European settlers because of his unorthodox views about working with the Malawian people. Scott attempted to reach out to the Malawians through contextualized mission work, allowing the indigenous people to hear about God without forcing them to change their culture and dispose of their traditions. This was perhaps one of the earliest contextualization attempts by Christianity in Malawi, but in 1898, Scott was forced to resign his post for health reasons and was succeeded by Rev. Hetherwick, who took over the responsibilities.' The Christian movement relied heavily upon European culture and ignored the Malawian traditions, such as circumcision, which were vital to the society of Malawi. In 1909, the Blantyre Mission established the Henry Henderson Institute for training teachers and other church workers. In 1926, the Dutch Reformed church joined the Livingstonia Mission which marked the beginning of the new era of the work of spreading the Gospel. The nationals were appointed to participate in various committees, and in $1933 \mathrm{Rev}$. Henry Matecheta became the first African moderator of the Blantyre Presbytery. ${ }^{2}$

Like other modern churches in Malawi, the Church of Scotland has continued to contribute to the preaching of the Gospel, medical work, and educational work. The Henry Henderson Institute still stands as a model for its academic excellence. The

\footnotetext{
${ }^{1}$ Crosby, 84.
}

${ }^{2}$ Ibid., 84-85. 
Church of Scotland operates many hospitals in all three regions of Malawi (North, South, and Central).

\section{Dutch Reformed Church}

The Dutch Reformed church originated in Cape Colony, South Africa. In 1889 , the first Dutch mission station in Malawi was established at Mvera to the west of Salima District. The church concentrated on rural developments because the missionaries believed that the best method of proclaiming the Gospel was to meet peoples' needs first. The church developed home industries and introduced new methods of farming.' Unfortunately, although the Dutch Reformed church did much to improve the economic situation in Malawi, this church also overpowered the Malawian culture, opposing circumcision and other rituals which did not fit the Christian ideals for society.

The mission station at Mvera was under the leadership of Rev. W. H. Murray and received financial support from the Dutch Reformed church in South Africa, which helped the missionaries to bring the Gospel to the unentered areas in Malawi. It is recorded that in the 1920 s the church managed to establish schools in many districts of Malawi, such as Mangoche, Ntcheu, Dedza, Nkhotakota, Mchinji, and Lilongwe. ${ }^{2}$ According to 1920 statistics, there were 10 established stations and 600 schools throughout the country, and the total church membership had increased to 15,000 .

\footnotetext{
${ }^{1}$ Nelson, 22.

${ }^{2}$ Murray, 242.
} 
Sixteen ministers were ordained to the Gospel ministry during this time, and 9 laymen and 17 women were employed to work for the church in various departments.

The Dutch Reformed church concentrated heavily on the Central region of Malawi among the Chewa people. The Nkhoma Mission in the central region was established as the Malawian headquarters for the Dutch Reformed church, although the church also opened mission stations in Mozambique. ${ }^{\prime}$ In 1895, Rev. W. H. Murray established the first boarding school for the girls under the leadership of Martha Murray. The missionaries believed that education was one of the important tasks in preaching the Gospel to the indigenous people and that when people are able to read and write, they can preach the Gospel to others.

The Dutch Reformed church merged with the Church of Central Africa Presbyterian (CCAP) in 1926. The three Protestant churches which merged together in spreading the Gospel are currently known as the Church of Central Africa Presbyterian (CCAP). This group of churches is divided into three synods: Blantyre Synod in the southern region, Livingstonia Synod in the northern region, and Nkhoma Synod in the central region of Malawi. ${ }^{2}$

\section{$\underline{\text { Roman Catholic Church }}$}

During the sixteenth century, the Roman Catholic church missionaries entered Malawi from Mozambique. The missionaries were not able to establish permanent

\footnotetext{
${ }^{1}$ Crosby, 85.

${ }^{2}$ Barrett, 471 .
} 
mission stations. In 1889 the church began to establish mission stations, ${ }^{1}$ and by 1904, the White Fathers (Montfort Marist) had managed to establish three permanent stations at Kachebere, Likuni, and Mua. The Montforts had two mission stations: Nguludi and Nzama. ${ }^{2}$ By 1920 the Montfort Marist Fathers had established nine mission stations in the southern region: Nguludi, Nzama, Neno, Utale, Nankhunda, Blantyre, Chikwawa, Limbe, and Nsanje. Like the missionaries before them, the Roman Catholic missionaries also emphasized education, preaching the Gospel, and medical work. However, the Catholics also attempted to change the Malawian culture, speaking out against the traditional customs, including circumcision, without regard for the damage this might have on the Malawian society. The missionaries were able to establish 17 secondary schools and 287 primary schools along with an Institute for Teacher Training at Nguludi and a seminary for training the people to become priests. In the medical work, the church managed to establish three hospitals. ${ }^{3}$

The first Roman Catholic Bishops to come to Malawi were French: Louis Auneaau, Joseph DuPont, and Mathurin Guilleme. The first three Malawians to be ordained as priests in the church were Cornelio Chitsulo, Alfred Finye, and Andreya Makoyo. Unlike the early Scottish missionaries, the Roman Catholic missionaries gave less freedom to the individual church members. The church was more authoritarian and could not allow the priests to break away and form independent

${ }^{1}$ Ian Linden, Catholics, Peasants, and Chewa Resistance in Nyasaland, 18891939 (Berkeley: University of California Press, 1974), 2.

${ }^{2}$ Crosby, 85 .

${ }^{3}$ Murray, 243. 
movements. ${ }^{1}$ The Catholic missionaries were believed to have the power to cause trees to wither and buildings to collapse, and some people still hold these beliefs. In my home village, the walls of a school being built by the Seventh-day Adventist church collapsed, and some people, including Seventh-day Adventist church members, believed that the local Roman Catholic priest had cursed the building, causing it to crumble.

The Roman Catholic missionaries believed that they represented a church with a cultural theological heritage of Western Europe. The African priests believed that they had a duty to serve God first and Africans second. The seminaries were not only primarily for training the priests but were meant to influence ambitious lay-Catholics. The Roman Catholic secondary schools provided the Catholic boys with the most advanced education. Kipalapala Seminary provided post-primary school for Catholic boys. Latin was taught by the most sympathetic teachers. The large number of Catholic boys attended seminaries because they saw that these seminaries provided education that could enable them to acquire good jobs. ${ }^{2}$

In the past, it was difficult for a non-Roman Catholic church member to be enrolled in the Roman Catholic schools. However, things have changed, and now people are able to attend Roman Catholic schools regardless of their religious affiliation. The Roman Catholic church has grown enormously both in membership, as well as in medical, industrial, and educational training throughout the country.

\footnotetext{
'Crosby, 85.

${ }^{2}$ Linden, 183.
} 
According to Felix Namakhuwa, a Union evangelist in Malawi, the Roman Catholic church has the largest membership of all Malawian churches. ${ }^{1}$

$\underline{\text { Islam }}$

In the nineteenth century, the Islamic religion was introduced to Malawi by the coastal Arabs who arrived as slave traders. Many people were converted to the Islamic religion when the slave trade was ended in the 1890 s by H. H. Johnston. Those converted to Islam were required to observe the feast of Ramadan and to take part in the rite of circumcision. Conversion to Islam also required observance of some rituals and prayers. The people were attracted to Islam because of the social status it offered beyond traditional faith. For example, Islamic teachers (Waalimu) were given money by the Islamic leaders in exchange for teaching students. ${ }^{2}$

As chapter 3 examines, the Islamic religion is strong among the Yao tribe. Today, 90 percent of the Yao people claim to be Moslems. Although the Roman Catholic church has a larger membership, the Islamic religion is growing at a fast rate in Malawi because of the Muslims' active evangelism. One possible reason for the popularity of Islam in Malawi is the Islamic acceptance and integration of cultural traditions into its religion. Circumcision, which has been opposed by the Christian churches in Malawi, is an important ritual in Islam. By contextualizing its teachings

\footnotetext{
'Felix Namakhuwa, telephone interview by author, 13 September, 1998. ${ }^{2}$ Crosby, 60 .
} 
and beliefs to cooperate with cultural traditions, Islam has managed to convert many people while allowing them to maintain their heritage.

Seventh Day Baptist Church

The Seventh Day Baptist church in Malawi was introduced to Malawi by Joseph Booth. In July of 1898 , while Booth was nominally connected with the proposed African Baptist Industrial Mission of the Negro National Baptist

Convention, ${ }^{1}$ he made contact with Seventh Day Baptist leaders. On September 24, 1889 , Booth became one of the active members of the Plainfield, New Jersey, Seventh Day Baptist church. Soon afterward, the African Baptist Industrial Mission was incorporated into the Sabbath Evangelizing and Industrial Association, an association for missionary work.

On the $19^{\text {th }}$ of April 1899 , Joseph Booth and his family left New York for Nyasaland (Malawi) on a missionary expedition. On July 16, he bought some land from German coffee growers and established a mission station thirty miles south of Blantyre. This mission station was called Plainfield after Booth's former church. In 1902, the Plainfield station was sold to the Seventh-day Adventist church. The Seventh Day Baptist church did not operate again in Malawi until 1947, when appeals were made to New Zealand, with support from Seventh Day Baptist members in the United States of America and Europe, to reopen the church in Malawi. The Seventh

${ }^{1}$ George Shepperson and Thomas Price, Independent Africa (Edinburgh, Scotland: University Press, 1958), 119. 
Day Baptist church set up its Malawian headquarters at its current location in Makapwa of the Thyolo District.

The Seventh Day Baptist church has many congregations in the north, south, and central region of Malawi, along with a medical center, a Pastor's Training Institute at Likubula in Blantyre, and primary schools throughout the country. The Seventh Day Baptist church has unintentionally contributed to the establishment of the Seventhday Adventist church in Malawi. The similarity of doctrines among the Seventh Day Baptists and Seventh-day Adventists in regard to the Sabbath has helped the SDA church to establish and grow faster among the areas of Malawi which were already exposed to the Seventh Day Baptist church. The Seventh Day Baptists and Adventists have also reacted in similar ways to the cultural traditions in Malawi; both churches have labeled traditional practices, such as circumcision, as being spiritually incorrect, while not attempting to understand the cultural and societal foundations for these rituals which make them so important to the Malawian people.

$\underline{\text { Seventh-day Adventist Church }}$

The years from 1891-1893 marked the establishment of the Seventh-day Adventist church in Malawi by a British lay-missionary George James who became the first Seventh-day Adventist missionary to Nyasaland (Malawi).

George James, born in London, England, played the violin and became a nightclub entertainer before accepting the Seventh-day Adventist message. In 1880, George emigrated to the United States of America. After becoming dissatisfied with his career as a night-club entertainer, he later joined the Seventh-day Adventist church. 
After experiencing conversion, he enrolled at Battle Creek College, where he developed a desire to do missionary work. In 1891 after graduation from Battle Creek College, he left for Africa after selling all he had except the violin which he used to attract the people when preaching the Gospel. George James traveled by ship to Malawi. He also used boats and was carried on a hammock (machila) by the local people.

In 1893, after a long trip he finally arrived in Blantyre, Malawi. James visited missionaries of other denominations and shared the Seventh-day Adventist faith with them. George James visited Joseph Booth in Blantyre, the leader of the Zambezi Industrial Mission at Mitsidi, a distance of five miles from the mission station of the Church of Scotland in Blantyre. Booth was later convinced of the truth of the seventh-day Sabbath and baptism by immersion. Thereafter he decided to have Sabbath worships and to set aside Sunday for outreach programs. Little is known about the work of George James, but the truth is that he visited the villages and played his violin, which attracted the people, before preaching the Gospel to them. He was loved by Africans, and the violin which he played was called "the box that sings." In 1894 , George James died on his way to Solusi College in Zimbabwe to meet with the Seventh-day Adventist missionaries, leaving Joseph Booth as his first convert to the Seventh-day Adventist faith with other native converts. ${ }^{1}$

\footnotetext{
${ }^{1}$ Beverly Herbrandson Koester, "Seventh-day Adventists Serving Malawi, 18931993," Mission, 30 April 1993, 13.
} 
In 1899, Joseph Booth returned to America to seek financial support for the missionary work in Malawi. In 1902, Booth, together with Thomas Branch, returned to Malawi under the sponsorship of the General Conference of the Seventh-day Adventist church. After their arrival, they bought a parcel of land in the Thyolo District in the Shire Highlands called Plain Field, which had been founded by the Seventh Day Baptists under the leadership of Joseph Booth before he joined the Seventh-day Adventist church. ${ }^{1}$

Thomas Branch continued teaching and preaching about the Ten Commandments to a few Sabbath-keepers. Soon the Seventh-day Adventist believers were nicknamed Amalamulo, meaning law or commandment keepers. In 1907, the name Plainfield Mission was changed to Malamulo Mission, and today the Seventhday Adventist believers in Malawi are called Amalamulo because of the emphasis on the Commandments in their teachings. Thomas Branch, with support from his family in mission work, led the foundation pattern of the Seventh-day Adventist church in Malawi. The significant point to note is that Thomas Branch made remarkable contributions to the development of the Seventh-day Adventist church in his educational, religious, medical, and publishing work.

The SDA church in Malawi has provided many Malawian men and women with various skills, contributing greatly to the development of Malawi through its educational, training, medical, and publishing services. The church operates hospitals, clinics, and primary and secondary schools in many parts of the country. One major

${ }^{1}$ Ibid. 
result of the work of the Seventh-day Adventist church has been the Ministerial Training School at Lake View Seminary in the central region. Dr. G. R. Doss and other SDAs contributed greatly to the development of this school, and their efforts have continued to empower the Lake View Seminary in its mission of training SDA leaders. Since the establishment of the Ministerial School, the church membership has grown at an astonishing rate. The 1998 Seventh-day Adventist Yearbook indicates the following total current memberships in the Malawian SDA churches: 37,404 in the Central Malawi Field, 29,212 in the North Malawi Field, and 134,429 in the South Malawi Field. ${ }^{1}$

Independence from Organized Christianity

This section briefly introduces the churches in Malawi which were started by Malawian nationals. Different reasons for the formation of independent churches in Malawi included: the historical background of the country, policies and activities of the Christian missionaries, and other social and cultural problems. These issues caused many of the indigenous people of Malawi to break away from the established Christian churches and to form their own independent church movements.

The Christian missionaries did much to improve the economic, educational, and spiritual conditions in Malawi. However, many of these independent churches were formed because of the conflict between traditional beliefs and customs and the Christian teachings. Although the missionaries greatly influenced the people of

${ }^{1}$ Seventh-day Adventist Yearbook, 73. 
Malawi, some of the Malawian converts were not satisfied with the missionaries' explanations and reasons for certain teachings. The Malawian cultural customs were ignored or opposed by the Christians, but the people were not given sufficient or clear reasons for this opposition. Since the Christian churches did not understand the Malawian culture, many indigenous Christian converts searched for alternative ways to reconcile their religion and their culture.

Most of the founders of the independent churches desired the freedom to control their lives and beliefs, instead of submitting to the missionaries. These independent churches were formed because the indigenous people felt that the Christian missionaries had failed to deal with the conflict between the churches and the Malawian society. In Malawi, many independent churches still continue to emerge, and many Malawians continue to turn to these churches in search of contextualized religion.

Providence Industrial Mission

The first African independent church established in Malawi was the Providence Industrial Mission, formerly known as the Ajawa Providence Mission, started by Rev. John Chilembwe. Chilembwe, a former servant of Joseph Booth, accompanied Booth in 1897 to the United States of America. Chilembwe received training at the Virginia Theological Seminary administered by the Virginia State Baptist Convention. After 
his return to Malawi in 1900, Chilembwe started the Providence Industrial Mission and a primary school near Blantyre. ${ }^{1}$

John Chilembwe's main concern was to address the social and economic conditions imposed by the British colonial masters, who were unfavorable to the Malawians. The Providence Industrial Mission expressed grievances against the British Colonialists, such as low wages, long hours of labor with low or no pay (Thangata), and poor treatment of the indigenous people by the White settlers. ${ }^{2}$ The death of John Chilembwe and his followers during the 1915 uprising against the White settlers led to the destruction of the Providence Industrial Mission. However, the church was restored by Dr. Daniel Sharpe Malikebu, a Malawian medical and theology graduate who returned from the United States of America in 1926. Because of his qualifications in the medical and theological fields, he was allowed to reopen the Providence Industrial Mission and assumed the leadership of the mission activities. This independent church has undergone several changes, such as in name and leadership, and it has also suffered from internal division. However, this church still continues to exist in many districts of Malawi. ${ }^{3}$

'McKitshoff, African Independent Churches (Lewiston, NY: Edwin Mellen Press, 1996), 25.

${ }^{2}$ Crosby, 58.

${ }^{3}$ McKitshoff, 26. 


\section{Watch Tower Movement}

In 1908, the second independent church in Malawi was formed: the Watch Tower Movement, brought to Malawi by Elioti Kamwana. Kamwana, who was formerly trained at Livingstonia Synod, left for the United States in 1901 and was introduced to the teachings of the Watch Tower Movement by Rev. Joseph Booth. In 1908, he returned to Malawi and led the Watch Tower Movement, especially in the northern region among the Tonga people. In that same year, 900 people were baptized, and the Watch Tower Movement has continued to spread rapidly through Central Africa. ${ }^{1}$

\section{Other Independent Churches}

From 1924 to the present, various independent churches have been formed in Malawi. The African Methodist Episcopal Church (AMEC) was established in 1924 by Hannock Msokera Phiri, a former member of the Livingstonia Mission. In 1926, the Zionist movement was developed, ${ }^{2}$ and the African National Church was founded between 1927 and 1929. The African National Church was established by Malawian men who had undergone training at Livingstonia Mission, including Jordan Msumba, Robert Sambo, Paddy Nyasulu, and Simon K. Mkandawire. The main existing branch of this church, the Abraham Church in the central region, has spread rapidly in many parts of Malawi. The Abraham Church holds many beliefs and practices which

\footnotetext{
'Ibid., 26-27.

${ }^{2}$ Ibid.
} 
conflict with the traditional Christian religion. For example, both children and adults are baptized, and the church permits polygamy, with restrictions to two wives for those who hold office positions in the church. The Abraham Church also allows people to drink beer, although its members are forbidden from participating in the circumcision ceremonies. ${ }^{1}$

One other independent church in Malawi was formed in 1934: the Church of Freedom (Mpingo Wa Wanangwa). This church was formed by Charles Chindongo, a former member of the Livingstonia Mission who had been ordained by Dr. Robert Laws. The main converts to the Church of Freedom were natives from the Livingstonia Mission. ${ }^{2}$

The independent churches which have arisen in Malawi are the result of indigenous efforts to preserve the Malawian culture while simultaneously spreading the Christian message. Some of these churches forbid circumcision, while others allow it, but by cooperating with the Malawian culture, these churches are more accepted by the people of Malawi.

\section{Conditions in Modern Malawi}

Major Tribes

Because of the slave trading which thrived in Malawi before the British intervention, many of the Bantu tribal groups were either dispersed or wiped out.

\footnotetext{
'Ibid., 28.

${ }^{3}$ Crosby, 58.
} 
Today, four major tribes form the population of Malawi: the Chewa, Tumbuka, Lomwe, and Yao tribes.

The Chewa people, who claim to have migrated from the Congo Basin, are located in the central region of Malawi. The Chewa people form the largest percentage of people in the districts of Lilongwe, Mchinji, Nkhotakota, Dowa, Kasungu, and Dedza of the central region of Malawi. The Chewa language (also called Chichewa) became the main language of Malawi during its struggle for independence from Great Britain in 1964. Chichewa was designated as the national language by the Malawian government in order to promote unity and communication between the Malawian tribes. By designating a national language, the new Malawian government hoped to curb the practice of tribalism, which was a major issue during the colonial rule, when languages had become one of the main identifying marks of the tribes.

The Chichewa language is spoken by Malawian people in almost all of the districts. Although other languages are spoken in Malawi, Chichewa is the language used by the mass media and for education instruction ${ }^{1}$ in government schools as well as in some private schools. In the early 1970s, some companies required applicants to pass a high-school course in Chichewa in order to be eligible for employment. The Tumbuka people dominate the northern region of Malawi, although other tribes do exist in this area. The Tumbuka people are a mixture of northern tribes: Henga, Kamanga, and other related tribes within the region.

${ }^{1}$ Nelson, 7. 
The other two major tribes in Malawi, the Lomwe and the Yao, are the focus of this study, since they are the two main Malawian tribes which practice circumcision rituals. The Lomwe, who constitute one-fifth of the Malawian population, are found in the districts of Thyolo, Mulanje, Blantyre, Zomba, Machinga, and Chiradzulu in the southern region of Malawi. The Yao people, like the Lomwe, are also found in southern Malawi, mainly in the districts of Mangoche, Chiradzulu, Blantyre, Zomba, Ntcheu, and Mulanje districts. The history of the Yao and Lomwe tribes is examined in more detail in chapter 3 of this study.

\section{Cultural Rituals}

This study focuses on one particular tradition: the ritual of circumcision. However, in Malawi this ceremony is predominantly carried out among the Lomwe and Yao tribes. Before concentrating on these two tribes, which are the exclusive topic of chapter 3, this study provides a brief overview of some cultural traditions and rituals which are currently practiced by the majority of Malawian tribes, in order to provide a modern cultural context for chapter 3 .

Among the various tribes of Malawi, certain activities or events are traditionally accompanied by ceremonies or rites of passage. These ceremonies include the nyau dances, a rite of puberty which is considered to be an initiation to manhood for the males of the tribes. The nyau dances serve a similar purpose as the circumcisions, which are examined in chapter 3. Childbirth also requires certain purifications and customs among the Malawian tribes. 
Health and illness affect the world view of many Malawians living in rural and urban areas. Among some Malawians, there is a belief that the spirits of the deceased speak to their relatives through dreams and mediums. In return, the descendants must offer sacrifices in the form of food and gifts to appease the spirits of the dead. In Malawian culture, the ancestral spirits are an underlying cause of illness. The ancestral spirits are regarded as distinctly human; certain spirits provide wisdom, while other spirits bring misfortunes, such as disease and death, to individuals and the community. Else Skjonsberg emphasizes that "ancestral spirits play different roles in the community; some give wisdom and favor, while others are petty, demanding, ready to hurt and even to destroy."1

Some Malawi communities associate illness with witchcraft. When an epidemic breaks out in a village, a diviner may be called to find out who has caused the disease. In the past, the diviner's suspects were exposed to the public and forced to drink natural poison (mwavi) to prove their innocence. Like the trials by fire or water of the European Middle Ages, those who died after drinking the special poison were considered witches, and their houses and property were destroyed.

In modern times, witchcraft and ancestral spirits are still blamed for the poor health conditions, infections, and malnutrition which are so widespread in Malawi. As chapter 3 shows, one tradition which reinforces these misguided beliefs is the circumcision ritual. The teachings which are associated with this ritual include lessons

\footnotetext{
${ }^{1}$ Else Skjonsberg, Change in an African Village: Kefa Speaks (West Hartford, CT: Kumarian Press, 1989), 165.
} 
about the powers of ancestral spirits and witchcraft. In order to protect and improve the spiritual, moral, and physical health of the Malawian people, they must first be brought to understand the spiritual, moral, and physical dangers which surround the circumcision ritual. This study now turns to a close examination of this popular but dangerous ritual and the two Malawian tribes which predominantly engage in this tradition: the Lomwe and Yao tribes. 
CHAPTER 3

\section{CIRCUMCISION RITUALS AND TEACHINGS \\ OF THE LOMWE AND YAO TRIBES}

\section{$\underline{\text { Introduction }}$}

The Lomwe and Yao tribes, who were introduced in chapter 2, form the focus of this study because they both practice circumcision; however, the circumcision practice is not unique to the Yao and Lomwe tribes. Circumcision rituals can be found elsewhere throughout East, Central, and South Africa. ${ }^{1}$ Among the Xhosa people of South Africa, the circumcision ceremonies "continue to be carried out in town, in nearly the traditional style, even among the committed Christians and the most highly-educated and the most fully-urbanized."2 In 1970, Marja-Liisa Swartz studied rituals and symbolism, including circumcision rituals, in coastal Tanzania. ${ }^{3}$ According to Colin Turnbull, African communities which practice circumcision consider this ritual to be a valuable societal initiation ceremony:

'A. P. Caplan, "Boys' Circumcision and Girls' Puberty Rites Among the Swahili of Mafia Island, Tanzania," African Journal 46 (1976): 30.

${ }^{2}$ E. J. De Jagar, Man: Anthropological Essays Presented to O. F. Raum (Cape Town, South Africa: C. Struik (Pty.), 1971), 8.

${ }^{3}$ Marja-Liisa Swartz, Ritual and Symbolism in Transitional Zaramo Society (Bocktryckeriaktiebolag, Sweden: Almquist \& Wiksells, 1970), 34-35. 
Initiation into a society unites new members in obligations toward each other. It creates new horizons for its members, binding together people who might otherwise feel no special bond. It also places initiates under the power of the spirits, making them more apt to be stricken with disaster should they transgress the tribal law. ${ }^{1}$

This perception of circumcision as a necessary preparation for adulthood is the main reason that ritual circumcision continues to be practiced in Africa. According to this belief, uncircumcised young men cannot "aspire to the knowledge of mature man"2 $^{\prime 2}$ until they are circumcised. Gilbert Okuro Ojwang, an Andrews University student from Kenya, adds that the circumcision ritual also "binds together those who are circumcised together throughout their lives. They [the circumcised boys] even have special names for each other, and there exists a great respect throughout the lives of those circumcised together." ${ }^{13}$

This chapter provides a closer look at the historical origins of the two Malawian tribes that practice circumcision as a mark of adulthood, the Lomwe and Yao tribes. This chapter also describes the circumcision rituals and teachings of these two tribes in order to explain the types of moral and physical dangers which currently face the people of Malawi.

'Colin M. Turnbull, Man in Africa (New York: Anchor Press Doubleday, 1976), 151.

${ }^{2}$ Swartz, 147.

${ }^{3}$ Gilbert Okuro Ojwang, interview by author, 3 January 1998. 


\section{$\underline{\text { Rites of Passage }}$}

It is important to note that circumcision itself is one representative of the traditional rites of passage which currently exist in many cultures of the world. Rites of passage, or "transitional rituals," are vital elements in their culture which symbolize the transition of a person or group of persons from one level or status to another within the society. ${ }^{1}$ A brief explanation of various rites of passage which follows provides useful knowledge of the role which circumcision plays for the Lomwe and Yao tribes in Malawi.

According to Arnold van Gennep, a leading anthropologist and sociologist, the activities which accompany ceremonies of social transition contain three major phases or types: separation, transition, and incorporation. The duration and intensity of each of these phases depends on the type of transition taking place. ${ }^{2}$ For example, at a funeral, there is a much more intense separation phase than an incorporation phase, while in a marriage, the separation from a single lifestyle can be a greater or lesser phase than the phase of incorporation to a married lifestyle.

The most popular rites of passage around the world are birth, initiation, marriage, and funeral rites. While each culture which practices a rite of passage may have its own unique activities for celebrating that transition period, the beliefs which accompany that rite of passage usually comprise the most significant aspect of the

\footnotetext{
'Paul G. Hiebert, Cultural Anthropology (Philadelphia: J.B. Lippincott Co., 1976), 160.

${ }^{2}$ Arnold van Gennep, The Rites of Passage (Chicago: University of Chicago Press, 1960), viii.
} 
entire cultural ceremony. ${ }^{1}$ Among the Lomwe and Yao tribes, circumcision, an initiation rite of passage, does not consist merely of the cutting of foreskins. The Malawian circumcision rite of passage also provides the youth with an understanding of tribal unity, an outline of their personal identity within the tribe, and their expected roles as mature tribal members. As the following chapters show, the dangerous influence of the circumcision ceremonies lies equally, if not predominantly, in the traditional teachings which accompany the ceremony.

The Lomwe and Yao tribes practice other rites of passage besides circumcision, while most of the Malawian tribes do not practice circumcision. This discrepancy may suggest that focusing solely on one rite of passage which is practiced by the males of only two Malawian tribes is not beneficial to the people of Malawi. However, van Gennep warns, "Although concern with the prevalence ... of different rites is a necessary consideration in the examination of any society . . . there is the danger that such routine or mechanical operation may ignore the theoretical problems [of the rites of passage]." ${ }^{2}$ The teachings associated with the circumcision rite of passage influence the Malawian society, and it is this rite of passage which forms the focus of this study.

${ }^{3}$ Ibid., ix.

${ }^{1}$ Ibid., viii. 


\section{Constraints}

This chapter is limited by two major factors which affect the verifiability of this study's sources. The first factor is the significant absence of written information regarding circumcision in the Malawian culture due to the traditional secrecy which surrounds the rituals. In order to overcome this lack of written information, I have chosen to rely heavily on oral information about circumcision which I gathered through interviews with Malawians and people from other African countries which have similar circumcision practices. Although these interviews provided me with very detailed, first-hand information about the rituals, they cannot be easily verified, like published or recorded sources.

However, even though interviewed sources can later be contacted in order to verify their information, some of my sources asked to not be cited by name in this study. This was a request which I honored in order to preserve their anonymity and to prevent members of their tribes from identifying these people. The act of exposing the traditional rituals to "outsiders," which is one of the results of this study, is a violation of the Malawian circumcision ethics and ancestral requirements. During the circumcision rituals, the initiates in both the Lomwe and Yao tribes are taught to maintain the secrecy of the rite by learning the Chewa phrase, $\underline{\mathrm{Za} \text { Kuthezo Saulula, }}$ which means, "Nothing must be revealed about the circumcision." The Lomwe and Yao tribes logically believe that revealing the secrets of the circumcision rites may frighten away tribal members who are not yet circumcised, causing the practice to lose its meaning and its impact on the traditional ties which bind the members of the tribal 
believe that the hazards which face my Malawian relatives and neighbors, along with the potential physical, moral, and spiritual benefits which this research could bring to Malawi, outweigh any cultural harm which my sincere efforts may have caused. I pray that the people of Malawi who examine this study in the future will be willing to fully consider what I have to say in the following chapters and then decide for themselves if their culture is endangered by the circumcision rituals. This is the first research of its kind to address the issue of circumcision in Malawi, and in order to encourage further research efforts, this study must firmly establish the importance of circumcision to Malawian religion, society, and culture. This study is not an attack on the Malawian culture, but simply an attempt to completely understand the circumcision ritual and use this understanding to suggest cultural changes which could preserve the health and social welfare of the people without destroying their culture.

\section{The Lomwe Tribe}

History

During the Bantu period of Malawian history, the Lomwe people migrated from Mozambique (formerly known as Portuguese East Africa), which is located alongside the east, south, and west borders of Malawi. The Lomwe people were originally called the Nguru, which was the name of the hill near where they lived in Mozambique. ${ }^{1}$ The Nguru migrated from Quelimane, a town in Mozambique, by a trade route along the upper Ruo River, which flows between Malawi and Mozambique,

${ }^{\mathrm{t}}$ Nelson, 78. 
into Malawi. During their travels, the Nguru changed their tribal name to Lolo, which effectually renounced their connections to Nguru Hill and Mozambique. In fact, the name Nguru became an insult to the Lolo tribe.

Once they settled in Malawi, the Lolo people changed their name again, this time to Lomwe. The Lomwe people settled in three different areas of Malawi and eventually became three separate tribal groups. The Lomwe who settled in a place called Milanje or Karithela, in the northeastern side of Malawi, were nicknamed Kokhola (forest) by the Manǵanja tribe because they lived in an area covered with thick forest and bushes. The second group of Lomwe settled near Marenje Hill along the banks of the Ruo River on the eastern side of Malawi and were named Amarenje. The Amarenje were feared and respected by the Kokhola tribe. The third Lomwe group settled near the Amarenje people and was named Thakhwani because of nearby Thakhwani Hill. The Amerenje and Thakhwani people are very similar; for example, they have only slight differences in their languages, and both tribes perform a traditional dance called Sekhere.

Among the three Lomwe tribes, various subgroups of people formed around certain geographical landmarks and are still found in those areas: ${ }^{1}$

1. Amanyawa: These people settled near a big tree called Manyawa. Their accent is similar to the Lolo from Chiwambo.

2. Alikhuku: This group settled along the Likhuku River inside Mozambique.

'Daniel L. Tsoka, The Story of Alomwe (Dublin: Cahil and Co., 1953), 2. 
3. Anohito: This group settled below the Likhuku River; their name is derived from the Lomwe word ohito, meaning "below."

4. Amaratha: These people settled near the hill called Maratha to the north of the Manyawa people.

5. Amihavani: These people settled in a sandy place (muhava) and were named accordingly.

6. Nyamwaro, Mihekani, and Malokotera: These were the names of the hills in Mozambique, therefore those who settled in these places were called by the names of the hills.

7. Angulu: This group of people settled along the banks of Lake Chirwa near Mangulu Hill.

These people speak Lomwe dialects, along with scattered groups of people found in the Mulanje, Thyolo, Chiladzulu, Blantyre, Zomba, and Machinga districts in the Southern region of Malawi. ${ }^{1}$

\section{Circumcision}

The Lomwe people perform their circumcision rituals annually during a certain period of time which begins in July and continues through October. Felix Namakhuwa, a Union evangelist for the Malawi Union of SDAs, confirms that the Lomwe season for circumcision ceremonies begins soon after the corn is harvested in the month of July and reaches its climax from August to October. This season is

'Ibid., 3-6. 
optimal since schools are closed during this time, which enables the children to attend the rituals. Namakhuwa further points out that there are no rains during this time of year, which would disrupt the ceremony. ${ }^{1}$ The regional tribal chiefs determine when each village or group of villages in their region will carry out the circumcision, in order for each circumcision ceremony to take place at a different time during the circumcision season.

\section{Rituals before Circumcision}

According to A. P. Yesaya, Union publishing director for the Malawi Union of the SDA church, the first step of the Lomwe circumcision rituals is when the village headman summons a group of people who have previously experienced the circumcision rites. This group beats drums during a specific time in the evening to draw the attention of the surrounding villages. During this time, all Lomwe families who have uncircumcised boys above the age of six make preparations for the ceremony.

In the Lomwe tribe, the rite is performed on boys six years of age and older. Sometimes, Lomwe boys who have lived outside of Malawi are not circumcised, and when they move to Malawi for work, school, or other reasons, they may desire to be circumcised. These boys usually wish to be circumcised in order to get married, since circumcised men are considered to be more eligible for marriage by some Lomwe women. Regardless of their age, Lomwe males are all circumcised together. These

\footnotetext{
${ }^{2}$ Felix Namakhuwa, telephone interview by author, 13 September 1998.
} 
traditions regarding age and marital status are also accepted by the Yao tribe, as is discussed later in this chapter.

The families gather corn flour from their friends and relatives; this flour, along with a certain amount of money, is given to the circumciser and also to their boy's guardian (mboziye) who will accompany their child and serve as a messenger between the boy and his parents during the ceremony. ${ }^{1}$ According to traditional Lomwe circumcision practices, the chiefs and headmen of the villages play the very important role of mediators between the family and the circumciser during the ceremony. The parents bring food and money to their village headman, who later gives it to the circumciser. This circumciser (nankungwi) is a circumcised man who is considered to be an expert in this ceremony. The circumciser is chosen by the people, and he carries out the ceremony every year.

The first part of the ceremony is designated for community celebration and is occupied by singing, dancing, and chanting. People of different age groups, both men and women, come from various villages to attend the ceremony. As soon as all of the boys to be circumcised have arrived, the dancing and singing are intensified and last for the whole night. During this time, the young men who have already been circumcised go door to door asking for food and money to be shared amongst themselves. Parents, friends, and relatives of the circumcision candidates become excited and give these young men a lot of food and money. This is a time of rejoicing

${ }^{1}$ A. P. Yesaya, telephone interview by author, 19 December 1998. 
because the Lomwe believe that the boys will attain adult status during the circumcision and refrain from doing childish things in the future.

J. S. Chingwalo, a layman of South Malawi field of the SDA church, states that upon the completion of the preparations, the boys are lined up next to their guardians and they leave the village and go to the place of circumcision in the bush far from the village. $^{\prime}$

\section{$\underline{\text { Rituals during Circumcision }}$}

When the boys arrive in the circumcision camp, accompanied by their guardians, the initiation ceremony begins. The boys are commanded to sit on the floor of a temporary hut made of grass (msasa) ${ }^{2}$ and each guardian stands behind his ward. The circumciser makes his appearance, dressed in a manner designed to frighten the boys. The boys are stripped naked and one boy is chosen to be circumcised first.

The boy to be circumcised is taken to another area where he is held by an older man, his hands are held tightly, and he is blindfolded so that he cannot see what is happening. The circumciser takes a sharp knife or razor blade (yoluma), cuts off the foreskin of the boy, and applies traditional medicines to speed up the healing. During the cutting of the foreskin, the boy endures the shock of the operation without any anesthetic. The circumcised boy feels much pain, and the other men intensify their

'J. S. Chingwalo, telephone interview by author, 17 December 1998.

${ }^{2}$ Ibid. 
singing and beating of drums in order to prevent the other boys from overhearing the screams.

The boys spend the next two months in huts at the circumcision site, recovering from the operation. During this time, the boys are subjected to various restrictions. For example, the boys are not allowed to eat relish in which salt has been added because of a traditional taboo which states that if the circumcised boys eat salted relish, they will develop swollen bellies (tsempho). ${ }^{1}$ The boys also suffer ordeals to test their endurance, such as taking cold baths early in the morning only four days after the day of the operation, missing meals, and sleeping on banana leaves or without a blanket. If a boy was disobedient to his parents and elders, the parents of the boy may previously direct the instructor to beat the boy severely during this time. In the past, if a boy died as a result of these beatings or any other of the trials he encountered during this time, he would be buried, and his parents would not find out about his death until the ceremony was over and the boys were sent home. However, this was such a terrible strain on the parents that eventually this custom was changed; now, when a boy dies during the circumcision ceremonies, his guardian returns to the parents and informs them so that they may retrieve the body for burial.

During the circumcision ceremonies, the boys are instructed about the traditional customs and values of the tribe. The boys are taught about proper behavior (miyambo), and these teachings are reinforced through circumcision songs (nyimbo za ku thezo). Some of the circumcision teachings contradict many Christian principles

'Ibid. 
and values; these teachings are examined later in this chapter. The circumcision initiates are given instructions ( previously circumcised men who attend the ceremonies. During the circumcision, traditional teachings are handed down from generation to generation, similar to the Western system of schooling, although the circumcision teachings do not address topics like reading and writing.

The teachings and activities related to the circumcision ceremony are maintained through secrecy and seclusion. The circumcision rites are performed in the deep bush areas far away from the villages to prevent other people from hearing the cries and screams of the circumcised boys during the painful operation but also to maintain the secrecy of the rituals. The only people allowed to attend the ceremonies are the circumcision candidates, the circumcisers, the guardians, and any men who have been previously circumcised and wish to share in the feasts during the ceremony. Any uncircumcised males of any age who are caught trespassing during the circumcision ceremony are forcibly circumcised, and all women found near the ceremony area are raped by the circumcised men. Finally, the circumcision candidates are threatened to maintain the secrecy of the circumcision. These practices have ensured the secrecy of the rites for many years.

\section{Rituals after Circumcision}

The ceremony after the actual operation is brief. When the circumciser and the other men are satisfied that the boys' wounds are healed and that they have received sufficient instruction, the boys are released to go back home. At this time, the initiates 
are bathed and dressed in new clothes, and their heads and faces are masked with a piece of cloth so that they are not seen by people while going home. The boys' guardians return to the village at night to alert the families, once again going door to door asking for food and money.

When the guardians return to the circumcision camp, the circumcised boys are released and commanded to not look back. The circumciser and other circumcised men remain to demolish the camp and offer sacrifices to thank the ancestral spirits for their protection from the evil spirits. Upon the arrival of the initiates, the villagers are not allowed to unmask them; each guardian waits to receive more money before unveiling his ward. This is a time of rejoicing for the parents and relatives, although in the past, it was also a time of sorrow for those whose children died during the ceremony.

The boys are kept in a small house apart from their parents for three days under the care of their guardians. Around 4 o'clock in the morning of the fourth day, the initiates eat food mixed with traditional medicine, and then the guardian takes the initiate to his parents. This marks the end of the circumcision ceremony. According to Lomwe tradition, every circumcised boy is now an adult with full responsibilities, regardless of his age, and is accepted as an adult by the society.

\section{Circumcision Teachings}

A general belief among the Lomwe tribe is that a boy's circumcision is a preparation for manhood. An uncircumcised male cannot be accepted as an adult in the Lomwe society until he has been circumcised. Circumcision is also a way of 
purifying and instructing the uncircumcised boys. Once a boy is circumcised, he is "clean" and is treated as an adult, regardless of his age. Circumcised boys are allowed to participate in certain things, such as funerals, burials, and marriage ceremonies, which can only be done by adults.

The beliefs taught during the circumcision seclusion affect the social attitudes and values of the boys. Certain circumcision teachings regarding personal body care and respecting parents, spouses, and friends are morally beneficial. For example, these instructions teach the boys to not enter their parents' bedroom, to avoid arguing with elderly people or speaking badly about them, and to help elderly people to carry heavy items. Family responsibilities such as respect towards spouses, responsibility for the welfare of the family, respect towards their parents and their wife's relatives, and observation of all marriage traditions and customs are taught during the circumcision.' These teachings are consistent with biblical teachings and improve the social and personal lives of the circumcised men and their families.

However, certain Lomwe teachings encourage the boys to believe in witchcraft, to worship ancestral spirits, and to practice sexual promiscuity. These teachings contradict and counteract the fundamental beliefs of Christianity. The Christian missionaries in Malawi have tried for many years to stop the rituals because of the unbiblical teachings which accompany them. Although Malawi has experienced social, religious, and economical changes in recent times, many of the Lomwe people, including committed Christians, educated people, and people who live in urban areas

'David Luwemba, interview by author, 23 December 1998. 
of Malawi, still believe that the rituals must be carried out. The Lomwe believe that abandoning the rites would provoke the ancestral spirits and bring chaos to their culture; therefore, the rites and teachings must be preserved until the end of the world, regardless of Christian opposition.

This section looks at some of the major cultural beliefs which are taught during the circumcision ceremony. These teachings directly contradict Christian beliefs about the state of the dead and the sanctity of marriage, and they also indirectly endanger the health of the people of Malawi.

Ancestral spirits

One of the most interesting Lomwe teachings is about ancestral spirits (mithimu), spirits of deceased ancestors who are concerned with living human beings. According to the traditional Lomwe teachings, life does not end when a person dies. This teaching, which is held by even some Seventh-day Adventists and other Christians in Malawi, states that the dead exist in another world which cannot be described by human beings. Although they live in another world, the dead still have interest in the affairs of the people and family members and keep watch over what is happening. These ancestral spirits are concerned about pressing issues in society such as illness, death, fertility, and drought. Like other cultures which believe in life after death, the Lomwe select items which belonged to a dead person and bury them with the deceased just in case the dead person should need them in another world. ${ }^{1}$

\footnotetext{
'Harry H. Johnston, British Central Africa (New York: Negro Universities Press, 1969), 444.
} 
The ancestral spirits appear through dreams and provide protection for their descendants. However, the spirits can also bring harm and chaos if they are not cared for by their descendants. 'Therefore, both in the circumcision ceremony and in everyday life, the Lomwe emphasize the need to appease the ancestral spirits. A common practice among the Lomwe tribe is to bury a deceased person in his/her home village in order to please the ancestral spirits. If the person were buried far away from the home village, the ancestral spirits would have to travel a long distance to visit the deceased person, which would displease them. Also, the ancestral spirits might not be able to visit the dead person because their powers do not extend to the particular territory where the person is buried.

According to Alice Takomana, a Malawian student at Andrews University, one of the practices in the past was to have separate graveyards for the Christians and for Muslims or non-religious people. The main reason for this separation is to allow the non-religious tribal people to carry out the necessary rituals to appease the ancestral spirits, such as spreading medicines on the grave and sweeping around the grave to keep the evil spirits away. ${ }^{2}$ Although it is contrary to Christian principles, the belief in ancestral spirits is held by both Christians and non-Christians in Malawi. The fear of ancestral spirits also serves to enforce beliefs and rituals regarding death, sex, and other aspects of the Lomwe culture. 1989), 72.

'Sandra T. Barnes, Africa's Ogun (Bloomington: Indiana University Press,

${ }^{2}$ Alice Takomana, interview by author, 17 December 1998. 
Witchcraft

The Lomwe people in both rural and urban areas of Malawi also believe in

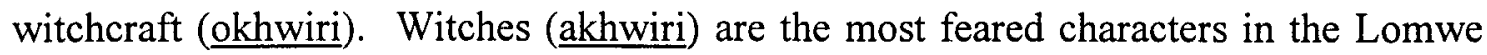
tribe. Witches supposedly eat human flesh and are capable of causing death by casting a secret spell on the person whom they want to kill. According to the Lomwe people, the main reason that witches cause a person's death is so that they can feast on the body after it is buried. The Lomwe believe that, after a body is buried in a cemetery, the witches come out at night and dance around the grave. The leader then commands the other witches to dig up the grave and remove the body, which is eaten by the witches.

The Lomwe people associate most illnesses, deaths, and unusual occurrences to witchcraft. "Deaths caused by natural causes and strange or sudden deaths are [all] believed to be caused by some witch or wizard."1 Even the increasing number of AIDS deaths among Malawians is attributed to witchcraft by some Lomwe communities. According to the Lomwe, death and sickness are caused by witches who go to people's homes at night, riding on a broom or a basket or in the form of a bat (muleme) or an owl (kukuru).

The belief in witchcraft is one of the teachings passed on to the circumcised boys during the circumcision ceremony. This belief not only affects the non-religious Lomwe, but it even influences Christians of different denominations, including the

'Cornelius Mulenga Matandiko, "A Christian Response to Zambia Death Rituals" (D.Min. dissertation, Andrews University, 1996), 24. 
Seventh-day Adventist church. This teaching supports the people's beliefs about ancestral spirits and gives them a distorted interpretation of death, which causes them to ignore the almighty power of God and to fear things which a true Christian does not need to fear.

Death

As explained in the previous sections, the Lomwe people believe that death can be caused by ancestral spirits or witches. Although the Lomwe believe that natural illness or old age (wuluvalha) can also cause death, any strange or sudden deaths are usually attributed to spirits or witches. The Lomwe believe that the ancestral spirits send messengers of death to the community as an signal (malodza) of death; when the jackal (nkhandwe) barks, the owl (kukuru) hoots, or the dove (ekhumda) stands with one leg raised for a long time, someone is going to die in the community. In some communities within the Lomwe tribe, the people offer sacrifices to appease the ancestral spirits when these messengers of death are seen or heard in the hopes of preventing death in their village.

According to Lomwe teachings, death is the time when evil spirits will try to kill other relatives of the dead person. Before the dead body is taken for burial, elderly women smear the floor of the deceased's house with mud. The Lomwe people believe that smearing the floor prevents the evil spirits from coming back to the house to claim the lives of the deceased's family members. As soon as the dead body is buried, the burial tools are carried by the young people and washed off in running water before they are brought home. The soil from the graveyard may contain evil 
spirits, so washing the dirt off of the tools is another way of keeping the evil spirits under control.

The Lomwe people, along with other tribes in Malawi, bury stillborn children (nthayo) right away in a special infants' burial ground. The women regard this burial ground as a sacred place, and there is an enormous amount of superstition mingled among the Lomwe tribe concerning the burial place for stillborn babies. During the burial of the child, men are not present and "the women do not even cry."1 Furthermore, the Lomwe believe that the spirits will disable the feet and legs of a person who steps on a nthayo grave. This is yet another way in which the ancestral spirits influence the actions of the Lomwe people.

Sexual behavior

The circumcision teachings which address sexual relations have harmful effects on the moral and physical well-being of the circumcised boys. These teachings emphasize sexual promiscuity as a way of proving the boys' masculinity. Most of the songs which are sung during the rituals contain sexual meanings and profane language. Also, the vicious and demeaning treatment of any women who trespass on the ceremony areas, which was previously described in this chapter, provides a powerful example for the boys about how they are expected to behave sexually.

The boys are instructed to have sexual relations with women after the ceremony in order to test their manhood and also as a means of ceremonial cleansing (kuchotsa

${ }^{1}$ Skjonsberg, 177. 
pfumbi). The circumcised boys are encouraged to "search for a spouse and [engage in] sexual activity."1 This early emphasis on active and widespread sexual activity has caused many young girls to be pregnant out of wedlock and has also increased the transmission of sexually transmitted diseases, which is examined in chapter 5 . Furthermore, this emphasis on sexual activity contradicts the concept of sex within marriage which God designed from the very beginning of the Earth.

\section{The Yao Tribe}

History

The Yao people originally lived near the Chao Hill between the Lujenda and Rovuma Rivers in the northeastern part of Mozambique. The traditional history of the Yao does not detail the exact cause of the Yao migration to Malawi. However, two separate researchers have concluded that the Yao migration was partly caused by internal conflicts ${ }^{2}$ and partly caused by attacks from the Makuwa tribe in Mozambique. $^{3}$

The Yao made contact with Arabs who were engaged in slave trading. Although the Yao were originally an agricultural people, their oral traditions and written accounts reveal that they migrated from Mozambique as slave traders. Bridglal Pachai states:

'Peter Rigby, Cattle and Kingship Among the Congo (London: Cornell University Press, 1969), 208.

${ }^{2}$ Yohanah Abdallar, Chikala Cha Wayao (The History of the Yao) (Zomba: Government Printer, 1919), 78.

${ }^{3}$ McCracken, 5. 
Long before the Yao began to move from this nuclear area into southern Tanzania and Southern Malawi, they were already established traders. In the 1730 s and the 1740s they were the greatest long-distance traders in East Central Africa, Southwest with Kilwa to Mozambique ... so the Yao had a firm foundation in coastal trade for hundreds of years before they came to Malawi in the nineteenth century as refuge settlers. ${ }^{1}$

The Yao worked as slave traders for the Arabs, purchasing or capturing people as the Yao traveled to Nyasaland (Malawi). These people were then sold into slavery to the Arabs or absorbed into the Yao culture.

Trading was the "occupational specialty"2 and major source of income for the Yao; they depended on the slave trade to maintain their social and economic structure. The Yao received firearms from the Arabs in exchange for the slave, and the Yao used these firearms to conquer neighboring tribes in Malawi ${ }^{3}$ and to acquire more land and slaves. The Yao governed these tribes, taking their cattle, land, slaves, wives, and absorbing their culture into the Yao system.

Under the leadership of two chiefs, Kapeni and Tambala, the Yao people completely conquered their neighbors in the southern areas of Malawi and then settled in the Mangoche Highlands (Fort Johnston). ${ }^{4}$ The Yao people now dominate the

'Pachai, Early History, 53.

${ }^{2}$ Violet Lucy Jhala, "The Shire Highlands: The Establishment and Maintenance of Yao Dominance Under Changing Socio-Economic Circumstances. 1861-1915" (Research seminar, Zomba University of Malawi, 1979-80), 4.

${ }^{3}$ Nelson, 19.

${ }^{4}$ B. R. Rafael, A Short History of Malawi (Limbe, Malawi: Popular Pub., 1982), 21. 
upper territory of the southern region of Malawi. ${ }^{1}$ The Yao language, Chiyao, is the official language of many parts of Malawi, especially in the southern region of the country.

The social and political organization of the Yao tribe is based on the "principle of Matrilineal decent." ${ }^{2}$ The Yao tribe has a well-organized pattern of chiefdom which is very similar to that of the Lomwe tribe. As this section shows, there are many other similarities between the Lomwe and Yao tribes, such as cultural practices, which stem from the common background of the Yao and Lomwe tribes: Both tribes migrated from Portuguese East Africa (Mozambique) to Nyasaland (Malawi). The main difference between the Lomwe and Yao people is their religion. Because of their extensive business contacts with the Arabs, the Yao people adopted the Islamic religion. Most of the Yao people in Malawi today are Muslims. ${ }^{3}$ On the other hand, the Lomwe tribe has been predominantly exposed to Christianity, and the majority of Lomwe people have accepted Christianity. However, the following section focuses on the circumcision rituals and teachings of the Yao, which are very similar to the Lomwe rituals and teachings.

\footnotetext{
${ }^{2}$ Denis F. Namate, The Emergence of the Yao as a Political and Economic Force in Mangoche: The Case of Mponda's Area, 1810-1910 (Chicago: Northwestern University Library, 1980), 2.

${ }^{3}$ Roland Oliver, The Middle Age of African History (London: Oxford University Press, 1967), 79-80.

${ }^{4}$ Frank Debenham, Nyasaland the Land of the Lake (London: Her Majesty's Stationery Office, 1955), 184.
} 


\section{Circumcision}

Among the Yao tribe, the circumcision ritual is an essential part of the Muslim religion. The Yao circumcision ceremony ( $\underline{\text { Jando }}$ ) is the official time when men become Muslim and is considered to be part of their salvation. The Yao believe that circumcised men are genuine Muslims for the rest of their lives. The religious significance of the Yao circumcision ritual has elevated men above women in the Yao tribe and also caused the Yao to perceive themselves as a special and unique people. The Yao perform the circumcision rituals during the same time period as the Lomwe, between July and October. Aside from its religious significance, the Yao circumcision is very similar to the Lomwe traditional circumcision: "There are elaborate ceremonies, including songs and dance, prior to and after the rite."1 The Yao circumcision also serves as a bush school (ndagala) where the initiates receive instructions in various skills and tribal customs and also receive discipline for their bad behavior. The extent of the similarities between the Lomwe and the Yao circumcision rites becomes more apparent in the following sections.

\section{Rituals before Circumcision}

Preparations for the circumcision begin when the parents of a boy decide he is ready to be circumcised. Yao boys can be circumcised once they reach the age of 15 , which is when the boys begin to develop sexual feelings. According to Yao tradition, circumcision prepares the boys for marriage, instructing them about marriage, sexual

'Ibid. 
behavior, and their relationship to their spouses. Like the Lomwe tribe, all the Yao circumcision candidates from a group of neighboring villages are circumcised together, regardless of differences in age or marital status.

The parents prepare gifts such as corn meal, chickens, and money to give to the chief. The first parents who give gifts to the chief to signal their son's readiness for circumcision are called nachilongola, which means to start. Upon receiving gifts from the nachilongola parents, the chief publicly requests the people in his community to send their boys for circumcision. The number of boys to be circumcised depends on the size of the tribal community. When the desired number of uncircumcised boys has been accumulated, the chief finds a qualified circumciser (nakanga) who will perform the ceremonies. During this time, the parents also select a guardian (aphungu or nzinake) for their boy. The guardian, a man who has been previously circumcised, will act as a messenger between the boy and the parents while the boy is in seclusion. According to L. Chinyama, pastor of the Ndirande Seventh-day Adventist church, the guardian is responsible to bring food from the parents to the initiate and to report the boy's condition to his parents. ${ }^{1}$ These guardians are paid for their work by the parents at the end of the entire ceremony.

Prior to the actual ceremony, the boys who have gathered together for circumcision are commanded to perform manual labors at the chief's house, such as mowing the grass and plowing in the fields. The boys also build a seclusion hut away from the villages; this hut is used during the circumcision ceremony. The night before

'L. Chinyama, telephone interview by author, 3 January 1999. 
the boys are taken to the circumcision area for the ceremony, a traditional dance called manganje is performed by the community. On the following day, the boys, accompanied by their appointed guardians, are taken into the deep bush where they will stay for a period of not less than three weeks.

\section{Rituals during Circumcision}

When the boys arrive at the place of circumcision, they are stripped naked and blindfolded, like in the Lomwe tradition. The actual circumcision is performed by the traditional circumciser (nakanga); the circumciser puts a finger into the foreskin, pulls on the skin, then cuts the foreskin with a sharp knife. Unlike the Lomwe tribe, the Yao do not apply any medication to speed up the healing, although sometimes they do apply Vaseline to the wound. While the operations are being performed, the singing and beating of the drums are intensified so that the boys cannot be heard when they cry out because of the pain. ${ }^{\prime}$

Traditionally, the period of seclusion which follows the actual circumcision is a time when the boys are separated from normal social relations. The initiates are beaten by men who have already been circumcised, even if these men are still very young. It is also customary for the parents to instruct the circumciser to beat their children severely if they were rude at home before the circumcision ceremony. Some Yao men who have endured the circumcision ceremony have observed that the boys

\footnotetext{
${ }^{1}$ Anonymous.
} 
experience punishment during the seclusion which is worse than the punishment given to a person in prison.

During the seclusion, the boys also receive various cultural and societal instructions from their guardians and other circumcised men who attend the ceremonies. The boys are instructed through the medium of special songs which are strictly reserved for use during this period. The teachings which these boys receive consist of traditional Yao attitudes and beliefs about respect, marriage, sex, death, and other topics. These teachings, which are very similar to those of the Lomwe tribe, are examined later in this chapter.

\section{$\underline{\text { Rituals after Circumcision }}$}

Like the Lomwe tribe, the post-circumcision ceremony among the Yao is brief. As soon as the wounds are healed, the circumciser and some of the village elders visit the campsite to confirm the release of the initiates. The initiates are dressed in new clothes and given Muslim names. The circumciser prepares a special medicine which he spreads around the camp site to prevent witches from practicing their magic on the place of circumcision. The Yao believe that if a witch comes to a place of circumcision that is protected by this medicine, he is trapped and cannot find his way out.

The night before they are released to go to their homes, the initiates are gathered together and several traditional dances are conducted at the chief's home. The chief makes a final announcement, and the boys are released as soon as each 
boy's parents pay the chief. When the fees are paid, each set of parents take their son home, marking the end of the circumcision ceremony.

\section{Circumcision Teachings}

Both the Lomwe and Yao tribes view circumcision as a time of status and behavior change for the boys. The rites prepare the boys for adulthood by presenting them with various instructions during the time of seclusion. For the Yao, these instructions include many important concepts such as obedience towards parents, relatives, and other elderly people and respect towards higher authorities, chiefs, and counselors. The boys also receive important sexual instructions about the design and functions of the male and female reproductive organs. However, the Yao circumcision rituals contain many beliefs which endanger the moral and physical health of the boys. These beliefs, which are very similar to those of the Lomwe tribe, are the focus of this section.

Ancestral spirits

Since most of the Yao people are Muslims, as noted earlier in this chapter, the Yao believe in a supreme God (Allah) who is the Source of power and "descends to the lowest heaven and calls out to humankind." ${ }^{\text {G }}$ God is the only "recipient of

\footnotetext{
'John Renard, Seven Doors to Islam (Berkeley, CA: University of California Press, 1996), 16.
} 
prayer"1 $^{\prime \prime}$ for the Yao people. However, the Yao, like the Lomwe, also believe that the spirits of their ancestors observe and influence their day-to-day actions.

During the circumcision, the boys are taught the importance of appeasing the ancestral spirits through the performance of many rituals and ceremonies. Special feasts ( sacrifices to the ancestral spirits. The rituals also include certain restrictions (kuthunda) which the entire village must follow while the boys are in seclusion during circumcision. All of the parents and relatives of the boys, as well as the chief, must refrain from sexual activity. The parents are not allowed to take a bath until the boys' wounds are healed, nor are they allowed to speak to anyone except the guardians and members of their family. Also, since the boys in seclusion are not allowed to dress, their mothers are not allowed to cover their breasts during this time. The Yao people believe that the ancestral spirits might kill the initiates if the parents and other villagers do not follow these requirements. ${ }^{2}$

The Yao believe that the ancestral spirits, if provoked, can cause illness, death, and misfortune in the family and society. They also believe that the ancestral spirits communicate to people through dreams. The fear of ancestral spirits plays a similar role for the Yao and Lomwe people: it enforces their beliefs about other rituals which must be performed in order to prevent retribution by the ancestral spirits.

\footnotetext{
'Amtiaz Ahmad, Rituals and Religion Among Muslim in India (New Delhi, India: Ramesh Jain, 1981), 70.

${ }^{2}$ Anonymous.
} 
Witchcraft

The Yao people believe in witchcraft, as do the Lomwe and many other tribes in Malawi. Supernatural power plays a very important role in the social life of the Yao; sorcery is believed to be the main cause of death, illness, and bad fortune for the

Yao. According to the Yao tribe, witches are superhuman agents of death and illness. Among the Yao, a person who threatens someone who later dies mysteriously is suspected of being a witch. The development of modern medicine, technology, education, along with the disintegration of rural communities, has weakened the belief in witchcraft among the Yao tribe. However, the Yao still believe that there are people who practice witchcraft and simply refrain from making threats in order to avoid suspicion. These witches supposedly employ special animals and birds, such as the hyena, owl, and dove, in their witchcraft. The Yao use charms to protect them against witches. These charms are placed along the corners of the house and also on the roof to prevent witches from coming to harm the family. Certain charms are also carried by individuals as they travel to protect them against these enemies. These teachings are passed on at the circumcision ceremonies and have a damaging effect on the Yao's image of God's power and superiority.

Death

Like the Lomwe tribe, the Yao tribe believes that death can be caused by ancestral spirits, witchcraft, or violation of the tribal customs. Old age or illness is accepted as the cause of death only if the person did not die in a strange, sudden, or inexplicable manner. Among the Yao, most of the death and burial rituals are marked 
by religious beliefs. The funeral service is held in a mosque if the deceased was a Muslim. The body is immediately buried after the ceremony, and mourning at the cemetery is strictly forbidden. The Muslim Yao believe that mourning at the cemetery is the noise of the devil.'

Sexual behavior

Sexual behavior is heavily emphasized while the boys are in seclusion. Most of the teaching songs which are sung during the ceremony have sexual language. During this period, it is expected for the men to talk about sexual things. Although the boys are taught about proper behavior for marriage, they are also instructed to become sexually active, regardless of their age. During the circumcision, the initiates are instructed to have sex with women of their age as soon as the circumcision is over.

The moral and physical effects of these teachings are very damaging to the boys. Sex is not considered to be a special concept which is preserved for marriage, and the boys' physical promiscuity has greatly contributed to the proliferation of AIDS throughout Malawi, as is shown in chapter 5.

\section{Conclusion}

This chapter presented the circumcision rituals and teachings among the Yao and Lomwe tribes, who are very similar except for their religion: the Lomwe are predominantly Christian, while the majority of the Yao are Muslim. The circumcision

'D.S. Roberts, Islam: A Concise Introduction (New York: Harper and Row, Pub., 1817), 129. 
teachings propagate and reinforce cultural beliefs which have a dual effect on the social and spiritual lives of these tribes. Chapter 4 of this study presents the biblical method of circumcision, which is opposed by the Lomwe and Yao rituals. Also, chapter 5 examines the ways in which the traditional circumcision rituals cause physical harm and the transmission of AIDS in Malawi. 


\section{CHAPTER 4}

\section{BIBLICAL CIRCUMCISION IN THE OLD AND NEW TESTAMENTS}

\section{Introduction}

The traditional circumcisions in Malawi incorporate many cultural rituals and teachings. Although some of these rituals and teachings are unhealthy and unbiblical, the act of circumcision was practiced and condoned by God's people in biblical times. As this chapter shows, the Old Testament circumcision was a physical operation which was very similar to the Lomwe and Yao circumcision operations of today, although the meaning of the Jewish circumcision was quite different from the Malawian cultural meaning. Although the New Testament applied circumcision to the condition of the soul, the practice of circumcision was used in both the OT and NT to symbolize a person's dedication to God. This chapter provides an understanding of the biblical origins and intentions for circumcision which can assist the people of Malawi to realize their need for biblical alternatives to traditional circumcision.

\section{Circumcision}

Origins

The OT contains four accounts of the rite of circumcision which provide insights into the origins of this ritual. The first account, located in Gen 17, tells how 
God covenanted with Abraham to form the people of Israel and to give them the land of Canaan. As a way of remembering this covenant, God told Abraham to circumcise all the males in his household from then on. The second account, in Gen 34, tells how Jacob's sons used the circumcision ceremony to gain revenge on Shechem the Hivite, who raped their sister. The brothers required Shechem and his relatives to be circumcised before Shechem could marry their sister; then, while the men were recovering, Jacob's sons attacked and killed them. The third account of circumcision is Exod 4:24-26, where Zipporah, the wife of Moses, "took a sharp knife and cut off the foreskin of her son." The fourth account of circumcision in the OT is in Josh 5:28, where the Lord appeared to Joshua and commanded him to circumcise the Israelites. This section presents various theories about the origins of circumcision which biblical scholars have devised, using these biblical accounts to support their theories.

Some scholars believe that circumcision existed before the formation of the Jewish people. H. H. Rowley and J. A. Soggin assert that circumcision was first practiced by Egyptians during the second millennium B.C., before the history of the Hebrews was developed. ${ }^{1}$ This belief was also promoted by Philo, who argued that the Egyptians devised circumcision because they were "most abounding in all kinds of wisdom" ${ }^{2}$ and that the other nations adapted this ritual because of the Egyptians'

${ }^{1}$ H. H. Rowley, Peake's Commentary on the Bible (Hong Kong: Nelson and Sons, 1962), 191, and J. A. Soggin, Joshua: A Commentary (Philadelphia: Westminster Press, 1972), 70.

${ }^{2}$ Philo, The Works of Philo, trans. C. D. Yonge (Peabody, MA: Hendrikson Pub., 1993), 534. 
popularity. P.C. Remondino suggests a slight variation to this theory: he believes that the rite of circumcision was first developed by the Phoenicians, adapted by the people of Egypt, and later integrated into the culture of the people of Israel. ${ }^{1}$

It is true that other nations besides Israel practiced circumcision during Bible times. Jer 9:25-26 clearly states that Egypt, Judah, Edom, Ammon, and Moab were "circumcised only in the flesh." However, some biblical scholars believe that the biblical accounts of Jewish circumcisions in Gen 17 and 34, Exod 4, and Josh 5 simply record the first Jewish adaptations of circumcision.

However, some scholars believe that Israel originated the rite of circumcision. The predominant view held by these scholars is that the circumcision was initially instituted by God as recorded in Gen 17..$^{2}$ Ronald Goldman states that the rite of circumcision originated in the Bible:

As a psychologist, my own speculative answer to the question of the origin of Jewish circumcision relates to the Torah account, specifically Gen 17:12-13: "As for the home born slave and the one bought from an outsider who is not of your offspring, they must be circumcised, home born and purchased alike." ${ }^{3}$

Gen 17 presents the clearest evidence that circumcision was instituted by God and that it originated in Israel. No other text in the Bible presents a clearer explanation of the origin of circumcision in Israel than Gen 17, and this text was

'P. C. Remondino, History of Circumcision from the Earliest Times to the Present (Philadelphia: F.A. Davis, 1891), 34.

${ }^{2}$ Meredith G. Kline, By Oath Consigned (Grand Rapids, MI: William B. Eerdmans Pub. Co., 1968), 40.

${ }^{3}$ Ronald Goldman, Questioning Circumcision: A Jewish Perspective (Boston: Vanguard Pub., 1998), 11. 
accepted in the New Testament as the biblical foundation for the origin of circumcision. ${ }^{1}$ Goldman agrees that Israel is the origin of circumcision "as mentioned in the Torah (Gen 17:6-13) where God promised Abraham, the first Jew."2 Thomas Schreiner also believes that Gen 17 presents the historical background of the origin of circumcision. $^{3}$

The account of Gen 17 is supported by Islamic tradition, which teaches that the first prophet to be circumcised was "Ibrahim when he was in his eightieth year."4 However, this teaching differs slightly from the biblical account of Gen 17:24, which states that Abraham was ninety-nine years old when he was circumcised in the flesh of his foreskin. According to Thomas Jemison, Abraham was one of the few people on earth during the early OT times who "stood out as a prospect to become the father of the great nation," ${ }^{5}$ and because of this, he was given the gift of prophecy by God and was recipient of the covenant which instituted the practice of circumcision.

Gen 17 details how circumcision was instituted by God as a symbol and mark of Israel as a chosen nation. In conclusion, although circumcision might have been

'Thomas Robert Schreiner, "Circumcision: An Entree into 'Newness' in Pauline Thought" (Ph.D. dissertation, Fuller Theological Seminary, School of Theology, 1983), 18.

${ }^{2}$ Goldman, Questioning Circumcision, 7.

${ }^{3}$ Schreiner, 18.

${ }^{4}$ Ian Richard Netton, A Popular Dictionary of Islam (Atlantic Highlands, NJ: Humanities Press International, 1992), 147.

${ }^{5}$ Thomas Housel Jemison, A Prophet Among You (Boise: Pacific Pub. Assn., 1955), 150. 
practiced by other nations, the practice and the meaning of it certainly have their roots in Gen 17.

\section{Uses}

Scholars have developed different theories about the purposes and uses of circumcision. The predominant view among scholars is that circumcision originally was a puberty rite which prepared a youth for marriage. Gen 34 and Exod 4:24-26 are often used to support this concept; the phrase "bloody husband" in Exod 4:26 is used to support the Genesis account of the sons of Jacob prohibiting their sister's marriage to an uncircumcised man. George Barton and William Dumbrell agree that the rite of circumcision was a necessary preparation for marriage. ${ }^{1}$

However, J. Morgenstern rejects this view of circumcision, arguing that the account of Gen 34 does not indicate that there was a relationship between the practice of circumcision and marriage. According to Morgenstern, circumcision among the Semites and the Jews was not a preliminary for marriage because "circumcision was a rite performed normally upon little children." ${ }^{2}$ Therefore, the rite of circumcision was not for children, who would have been too young for puberty or marriage, so Morgenstern and Lewis's theory appears to be a more probable reason for early Jewish circumcision rites.

'George Aaran Barton, Semitic and Hamitic Origins (Philadelphia: University of Pennsylvania Press, 1934), 149, and William Dumbrell, Covenant and Creation (Nashville: Thomas Nelson Pub., 1984), 74.

${ }^{2} \mathrm{~J}$. Morgenstern, Rites of Birth, Marriage, Death, and Kindred Occasions Among the Semites (Cincinnati: Hebrew Union College Press, 1966), 56. 
Other views about circumcision also exist. The Arabs hold an interpretation of circumcision which views it as a sacrifice being offered to the deity of fertility. ${ }^{1}$ Albert Shulman states that the rite of circumcision must have been associated with tribal or clan blood rituals as a substitute for sacrifice. ${ }^{2} \mathrm{H}$. Ewald agrees with Shulman that the rite of circumcision was originally intended to be a substitute for human sacrifice. ${ }^{3}$ In Exod 22:29, God commanded the Jews to give their firstborn sons to Him. In heathen cultures of the OT time period, children were given to gods by being sacrificed on an altar. However, since the Jews did not practice human sacrifice, it is possible that circumcision was a symbolical way of offering up their sons to God. Among the Jews, circumcision also served to cleanse the newborn child from the uncleanliness of being born. ${ }^{4}$ This belief was probably based on the Torah, which states:

If a woman have conceived seed, and born a man child: then she shall be unclean seven days; according to the days of the separation for her infirmity shall she be unclean. And she shall then continue in the blood of her purifying three and thirty days; she shall touch no hallowed thing nor come into the sanctuary, until the days of her purifying be fulfilled. (Lev 12:2,4)

Lewis supports this argument by pointing out that "circumcision came into existence among the early Hebrews as a blood sacrifice. ... It was a blood sacrifice on behalf

'Barton, 148.

${ }^{2}$ Albert M. Shulman, "Gateway to Judaism," Encyclopedia Home Reference, vol. 1 (New York: Thomas Yoseloff, 1971), 458.

${ }^{3} \mathrm{H}$. Ewald, The Antiquities of Israel (London: Longmans Green, 1896), 93.

${ }^{4}$ Morgenstern, 63-65. 
of the boy to cleanse himself of the contamination of having come in contact with the mother's 'uncleanliness'."1

Circumcision may have also been used as a method of bringing slaves under control; circumcision was forced upon slaves in order to mark them as property of their master and to symbolize their master's power over them. ${ }^{2}$ Finally, according to Jacob Minkin, the rite of circumcision could have also been practiced in order to decrease sexual intercourse and control the population. The rite of circumcision controls excessive desires for sex and weakens sexual excitement by weakening the circumcised male's sexual organ. ${ }^{3}$

\section{Circumcision in the Old Testament}

Biblical Meaning and Origin

Although all of the above theories are viable reasons for which circumcision may have been designed, Keith Krim argues that the rite of circumcision was instituted by God in Gen 17:10-12 as a symbol of the covenant in the flesh between God and the children of Israel. ${ }^{4}$ Abraham Bloch supports this theory, claiming that the rite of circumcision was instituted by God in Gen 17:9-14 as a precedent for the Sinatic

${ }^{1} \mathrm{~J}$. Lewis, In the Name of Humanity (New York: Eugenies Pub., 1949), 26.

${ }^{2}$ T. Beidelman, The Encyclopedia of Religion (New York: MacMillan Pub., 1987), 3:511.

${ }^{3} \mathrm{Jacob}$ S. Minkin, The Teachings of Maimonides (Northvale, NJ: Jason Aronson, 1987), 274. 186.

${ }^{4}$ Keith Krim, "Circumcision," Abingdon Dictionary of Living Religion (1981), 
revelation which God gave to His people many centuries later. ${ }^{1}$ The circumcision ceremony was a symbol which God used in the same manner as the Ten Commandments: it was a way for His people to show their allegiance to Him. Orthodox Jewish beliefs state that the rite of circumcision was instituted by God as a symbol of loyalty and covenant. ${ }^{2}$

Along with being one of the qualifications for a Jewish male to achieve full membership in the Jewish society, circumcision is also a Jewish symbol of the covenant between God and the children of Israel. Isaac Klein points out:

Of all the signs and symbols in the Jewish tradition, none is more widely known than circumcision. . . Circumcision for the Jew is the sign of the $b^{\prime} r t$, the covenant between God and Israel, established first with Abraham and then renewed at Sinai, to be passed on through every generation until the end of time. $^{3}$

An example of the symbolism behind circumcision is given in Josh 5:2-7, which details how God used circumcision to remind the children of Israel of His promise to their ancestors to bring them out of Egypt and into the land of milk and honey, Canaan.

God promised Abraham that He would multiply his descendants and give them the land of Canaan. In order to seal this promise, God set up a ritual: "Every male among you [the Jews] shall be circumcised" (Gen 17:10). The fulfillment of this

\footnotetext{
${ }^{1}$ Abraham P. Bloch, The Biblical and Historical Background of Jewish Customs and Ceremonies (New York: Ktav Pub. House, 1980), 1.

${ }^{2}$ Oxford Dictionary of the Jewish Religion (1997), s.v. "Circumcision."

${ }^{3}$ Isaac Klein, A Guide to Jewish Religious Practice (New York: Ktav Pub. House, 1979), 420.
} 
covenant between God and his people required an irreversible action: a mark on the flesh. The circumcision ritual, which began at this point in history, reminded the Jews of their ancestry and religion; furthermore, after the Babylonian exile, the rite of circumcision became a distinguishing mark of the Jews and a sign of God's covenant to send a Messiah to them. ${ }^{\prime}$ An example of the distinguishing function of circumcision is in the book of Jeremiah, where circumcision was used to designate the people of God (Jer 9:25-26).

Through Mosaic law, circumcision became obligatory among every Jewish family, and omission or neglect of circumcision by a Jew was a transgression of the Torah punishable by death. The importance of this ritual was expressed in Gen 17:14, where God commanded Abraham to exclude any uncircumcised man from God's people. In the OT Jewish culture, an uncircumcised man was an unclean, unconsecrated, and a pagan person who could not remain in the Jewish community, for fear that he would contaminate God's people through his disobedience of God's law. In Jewish tradition, to renounce the rite of circumcision was similar to renouncing one's Jewish heritage and religion. It was believed by the Jews that the strength of their economy depended on their loyalty to religious ceremonies and obedience to God, of which circumcision was one of the ceremonies. According to Mosaic Law, an uncircumcised Jew must be separated "from the rights and privileges belonging to an

$$
\text { 'Bloch, } 8 .
$$


Israelite."1 Uncircumcised Jews were not allowed to participate in political, social, and religious issues. Remondino points out that the practice was "of a very religious and national nature,"2 comparing it to the experience of Pythagoras, who was compelled to be circumcised before being allowed to study in the Egyptian temples. ${ }^{3}$

The OT indicates that circumcision had a deep cultural significance for the Jews. The rite of circumcision identified the Jews as the children of God, a peculiar people. Ellen White states that circumcision "was to be observed by the patriarchs ... as a token that they were devoted to the service of God." ${ }^{4}$ Circumcision was a mark of the Jews' opposition to idol worship, but, eventually, it became a symbol which separated the Jews from the Gentiles and supposedly excluded the Jews from defilement. ${ }^{5}$ This egotistical view of circumcision was accepted and maintained by the Jews in the New Testament era, where the rite of circumcision "became a mark of racial and cultural pride" ${ }^{\prime 6}$ for the Jews. However, by viewing circumcision as the only requirement for salvation, the Jews of the NT blinded themselves to the mission of Christ, a mission which also encompassed the Gentiles, and the spiritual results of

1"Genesis," SDA Bible Commentary, ed. F.D. Nichol (Washington, DC: Review and Herald Pub. Assn., 1976), 1:323.

${ }^{2}$ Remondino, 34 .

${ }^{3}$ Ibid.

${ }^{4}$ Ellen G. White, Patriarchs and Prophets (Boise, ID: Pacific Press Assn., 1958), 365.

${ }^{5}$ Schreiner, 71.

${ }^{6}$ Merrill C. Tenny, "Circumcision," Zondervan Periodical Encyclopedia of the Bible (Grand Rapids, MI: Zondervan Pub. House, 1975), A-C:866. 
this blindness are examined later in this chapter. Fritsch states that circumcision became "the outward sign of membership in a community of faith with all of the privileges pertaining thereto." 1

Circumcision among the Jews also served as a way to continue the Jews' relationship with God. The ritual was a symbol and pledge of submission to God. Ellen White states that the reason for the Jewish bondage in Egypt was that the Jews failed to keep their pledge to God and formed "alliances with the heathen and adopted their customs." ${ }^{2}$ This was a failure to maintain their relationship with God.

The circumcision ritual was very important, and God strongly emphasized circumcision as a requirement for the Jews. A clear example of this emphasis is the story in Exodus of Zipporah circumcising her son:

And it came to pass by the way in the inn, that the Lord met him [Moses] and sought to kill him. Then Zipporah took a sharp stone and cut off the foreskin of her son and said, "Surely a bloody husband art thou to me." So he let him go: Then she said, "A bloody husband though art because of the circumcision." (Exod 4:24-26)

God was willing to take the life of Moses, the future deliverer of Israel, because his younger son, Eliezer, had not been circumcised. ${ }^{3}$ The severity of God's punishment in these verses for ignoring the circumcision ritual proves that circumcision held a major role in the Old Covenant between God and His people.

'Charles T. Fritsch, The Layman's Bible Commentary: Genesis, vol. 2 (Atlanta: John Knox Press, 1982), 64.

${ }^{2}$ Ibid., 363.

3"Exodus," SDA Bible Commentary, ed. F.D. Nichol (Washington, DC: Review and Herald Pub. Assn., 1953-57), 4:29. 
Finally, circumcision provided a way for fallen humanity to be perfect in God's eyes. Gen 17 indicates that Abraham was not perfect until he was circumcised, following the requirement of God. The need for attaining perfection through circumcision is made clear by God's command, "I am Almighty God; walk before me, and be thou perfect" (Gen 17:1). This expression was made before the ratification of the covenant between God and Abraham, which indicates that Abraham was not perfect until he was circumcised (Gen 17:24). The rite of circumcision among the Jews contributed to salvation, atonement, and perfection.

The Jews have continued to observe the rite of circumcision as a symbol of obedience to the covenant formed between God and Abraham. God intended for the rite of circumcision to be passed from one generation to another as a lasting symbol of His love for His people, the Jews. Circumcision has survived among the Jews through times of peace and persecution, from "the misty epochs of the Stone Age to the present." In 167 B.C., the Greek king, Antiochus Epiphanes, issued a decree forbidding the practice of circumcision and prescribing the death sentence for every Hebrew mother who dared to practice circumcision. ${ }^{2}$ The Jews overthrew this decree during the Maccabean revolution against Antiochus, ${ }^{3}$ but the rite of circumcision was later prohibited again during the time of Constantine. ${ }^{4}$ However, despite all of these

\footnotetext{
'Remondino, 67.

${ }^{2}$ Ibid., 66.

${ }^{3}$ Geoffrey Wigoder, The Encyclopedia of Judaism (New York: MacMillan Pub. Co., 1989), 167.

${ }^{4}$ Remondino, 67.
} 
and other attempts to eradicate the Jewish rite of circumcision, it has continued to be a vital and active part of the Jewish culture and religion.

In conclusion, the OT rite of circumcision was important for several various reasons:

1. It was a vital part of the covenant between God and the Jews.

2. It was a way to gain favor with God and maintain a relationship with Him.

3. It was a means of salvation in the Jewish religion. ${ }^{1}$ Jews who revolted against circumcision were to be cast out from God's people, while those who were circumcised showed their belief in a coming Messiah.

\section{The Old Covenant}

The Covenant made between God and Abraham in Gen 17 is analogous to a covenant between a Suzerain (ruler) and a vassal, which is called a berith. In a berith, the ruler who makes the covenant binds himself to the covenant and then pronounces the blessings and curses which will accompany it. In this type of covenant, the person who is stronger seeks to maintain a relationship with the weaker. The one who initiates the berith exerts power over the recipient. The Suzerain-vassal type of covenant also has elements of a consecration service under dual agreement. Kline states that the covenant of Gen 17:14 is symbolized through the rite of circumcision. ${ }^{2}$ Furthermore, Kline notes that "the general and specific considerations unitedly point to

\footnotetext{
${ }^{1}$ White, Patriarchs and Prophets, 138.

${ }^{2} \mathrm{Kline}, 41-42$.
} 
the conclusion that circumcision was the sign of the oath-course of the Covenant ratification."1

A comparison of the covenant in Gen 17 with the covenant which God made with Abraham in Gen 15 exposes some subtle meanings about the relationship between the Old Covenant and circumcision. Gen 15 is an introduction of God as the initiator of the Covenant between Himself and His children, while Gen 17 expands a new dimension of the Covenant, focusing on the response of Abraham and his descendants to God's commands. Dumbrell examines the similarities between Gen 15 and 17, stating,

Like [Genesis] chapter 15, Gen 17 begins with divine appearance to which there is an appropriate response by Abraham (cf. 17:1-3a with 15:2-3). The substance of the promise of descendants and their significance is repeated (cf. 17:4-6 with 15:4-5), while the covenant is confirmed between the parties including Abraham's descendants with particular reference to the land (cf. 17:7 with $15: 7-12)^{2}$

Genesis chaps. 15 and 17 do not contradict each other; they are complementary to each other. Kidner states that the Covenant of chap. 15 was based primarily on grace and faith. In Gen 15, Abraham was not asked to do anything but to believe and have faith in God. However, Gen 17 emphasizes the need for faith in action: the dedication of the entire generation through the symbolical seal of circumcision. These

${ }^{1}$ Ibid., 43.

${ }^{2}$ Dumbrell, 75 . 


\section{Physical Circumcision}

Physical circumcision of the male sexual organ plays a major role in the Old Covenant. Michael Asheri defines circumcision from this view:

Circumcision ... is our signature on the contract (covenant) that God made with us when He chose us as His people. Through circumcision, every Jewish male actually signs that contract with God with his own blood and the seal of his signing is evident in his flesh as a contract and non-erasable reminder. ${ }^{1}$

The irreversability of physical circumcision mirrors God's unchanging grace and His everlasting relationship with His people. According to Wigoder, circumcision is "the sign of an everlasting covenant."2

The rite of circumcision is also a requirement for membership in the Covenant. Pieters asserts that the Covenant was a contract between God and Abraham and his descendants through which the children of Israel became the children of God. ${ }^{3}$ Mitchell adds, "Circumcision was the visible sign of commitment to the Lord, the response to the Lord's commitment of Himself, in covenant to those who looked for Abraham's promised seed." ${ }^{\prime 4}$ Fritsch also defines the rite of circumcision as the outward symbol of the Abrahamic Covenant. ${ }^{5}$ God and Abraham were both obliged to fulfill the promises of the covenant. God's duty under the covenant was to fulfill

'Michael Asheri, Living Jewish (New York: Everest House, 1978), 35.

${ }^{2}$ Wigoder, 167.

${ }^{3}$ Albertus Pieters, The Seed of Abraham (Grand Rapids, MI: William B. Eerdman's Pub. Co., 1950), 14.

${ }^{4}$ John J. Mitchell, "Abraham's Understanding of the Lord's Covenant," Westminster Theological Journal 32 (1969): 41.

${ }^{5}$ Fritsch, 64. 
His promises to Abraham through his descendants. In turn, Abraham and his descendants were obliged to practice the rite of circumcision as a physical symbol of fulfilling their covenant with God.

\section{Jewish Circumcision Rituals}

This section provides a detailed look at the rituals which accompany circumcision among the Jews. After examining the traditional and medical explanations for the specific day of circumcision which God designated in Gen 17, this section describes the rituals which take place before, during, and after a Jewish circumcision ceremony. In combination with the description of Malawian circumcision rituals in the previous chapter, this section provides the proper information by which to compare the similarities and differences between Jewish and Malawian traditional practices of circumcision.

\section{Time of Circumcision}

God commanded Abraham to circumcise newborn boys on the eighth day after their birth (Gen 17:12), and the Jews traditionally continued to perform circumcision on the eighth day. The circumcision on the eighth day superseded the importance of the Sabbath in Jewish culture; the circumcision had to be performed "even if that day falls on Sabbath."1 Although God's designation of the eighth day for circumcision seems arbitrary, scholars and medical doctors have come up with various explanations which prove that the eighth day is a good time for performing the rite of circumcision.

${ }^{1}$ Krim, 186. 
According to Jewish tradition, the newborn child was imperfect until he reached the eighth day. Therefore, circumcision performed after or before the eighth day was a violation of the requirements of the Torah as commanded by God, and such was made void. Furthermore, in view of Sabbath observation, the eight-day interval gave the baby a possibility of experiencing the Sabbath before the circumcision, which was important according to Jewish tradition.'

Minkin points out two additional reasons in Jewish tradition for carrying out the circumcision at such an early age:

1. If the operation was postponed until the child matured, he might not submit to the rite of circumcision.

2. The child would not be afraid of the procedure because he would not think about it before it happened. Furthermore, the child would feel less pain than an adult would, because his young skin would be tender. ${ }^{2}$

Minkin's statement that the child feels less pain is supported by James Lee, who claims that a child does not feel as much pain as an adult person would feel during circumcision, since the child's flesh is less compact. ${ }^{3}$ However, Annard and Hickey reject this theory. They argue that, based on observation of infants' behaviors

${ }^{1}$ Klein, 426.

${ }^{2}$ Minkin, 275.

${ }^{3}$ James W. Lee, Genesis to Joshua, The Self Interpreter's Bible, vol. 1 (St. Louis: Thompson Pub. House, 1905), 240. 
during circumcision, babies feel similar or greater amounts of pain as adult circumcision subjects. ${ }^{1}$ Goldman agrees with Annard and Hickey:

During circumcision, which is typically performed without anesthesia, infants display significantly more distress than during other procedures. Physiological and behavioral change are abnormal and extreme. The latest research studies all support the conclusion that circumcision is overwhelmingly painful for infants. $^{2}$

Charles Schlosberg's study on ritual circumcision takes a middle ground to these opposing views. Scholsberg does not claim that children do not feel pain during circumcision, but he maintains that "circumcision at eight days of age . . gives the child a chance to reach general physiological homeostasis following birth." ${ }^{3}$ In other words, the eight-day waiting period allows the baby's body to mature enough to withstand the shock and pain of circumcision.

$\underline{\text { Rituals before Circumcision }}$

Traditionally, Jewish circumcision activities began on the first Friday night after the birth of the child. The ceremony was held on Friday night because, by Jewish tradition, everyone was home on Friday night in preparation for the Sabbath.

${ }^{1} \mathrm{~K}$. Annard and P. Hickey, "Pain and Its Effects in the Human Neonate and Fetus," New England Journal of Medicine 317 (1987): 1326.

${ }^{2}$ Ronald Goldman, Circumcision: The Hidden Trauma (Boston: Vanguard Pub., 1992), 27.

${ }^{3}$ Charles Schlosberg, "Thirty Years of Ritual Circumcision," Clinical Pediatrics 10 (April 1971): 205-209. 
Family, friends and neighbors gathered together at the parents' home and spent the night in prayer. ${ }^{1}$

The Friday night ceremony was preceded by the singing of Sabbath hymns, lighting of candles, a presentation of the Torah message, and light refreshments. Although the candles may have originated as a symbol of worship, they later were used to secretly inform other Jews of a circumcision. During the times of Jewish history when circumcision was prohibited, candles were lit in the window of a house in order to alert interested Jews about an upcoming circumcision. Cohen states, "The custom of lighting candles at a Brith Milah [circumcision] originated at a time when it was illegal to perform a brith." ${ }^{2}$ Perling explains that the candles were also lit during the actual circumcision ceremony "so that the passers-by would know that circumcision was about to take place, and come in to witness the ceremony."

Although the circumcision was supposed to take place on the eighth day, it could be postponed because of "illness and anomalies." ${ }^{4}$ Usually, circumcision was not postponed unless the child had poor health. Before the eighth day, a physician or the Mohel (circumciser) would examine the child's health. If the child was sick, the circumcision rite was postponed until the child was better. This was in accordance

\section{'Bloch, 3.}

${ }^{2}$ Eugene J. Cohen, Guide to Ritual Circumcision and Redemption of the First Born Son (New York: Ktav Pub. House, 1984), 38.

${ }^{3}$ Abraham Isaac S. Perling, Reasons for Jewish Customs and Traditions (New York: Block Pub. Co., 1968), 271.

${ }^{4}$ Hayim Halev Donin, To Be a Jew (New York: Basic Books Pub., 1972), 274. 
with Jewish law, which prescribed caution and delay.' Another valid reason for delaying the circumcision was if other children in the family had died previously during circumcision. The Oxford Dictionary of the Jewish Religion states, "The only exception permitted to the otherwise universal requirement of circumcision is if two previous children of the family have died as a result of the operation; that is, in case of hereditary hemophilia." ${ }^{2}$

Rituals during Circumcision

Although the actual circumcision operation was very brief, the ceremony surrounding the operation lasted a whole day, beginning from the rising of the sun. Early on the day when the operation was to be performed, a minyan (special group) of religious men, including the Mohel, the father of the child, and the Sandek (godfather) would gather in a room designated for the circumcision ceremony. The child would be with his mother in a separate room. During the ceremony, the mother could not be seen by any men, including her husband. The father of the child would appoint a man to bring the child from the mother to the place of circumcision. According to Jewish tradition, even this man could not actually receive the child from the mother; instead, the man's wife would go to the mother, bring the child to the chosen man (her husband), and this man would take the child into the place of circumcision.

'Asheri, 35.

${ }^{2}$ Oxford Dictionary of the Jewish Religion (1997), s.v. "Circumcision." 
As soon as the man bearing the child entered the room, everyone in the minyan would stand up, except for the godfather, who remained sitting in the Chair of Elijah. This chair is discussed later in this chapter. The Sandek would hold the child in his lap, then hand the child over to the Mohel. The Mohel recited blessings on the child, and then performed the operation on the boy's penis. As soon as the foreskin was cut, the father of the child recited blessings upon the child, expressing thanks to God for the covenant established with their ancestor, Abraham.

Upon completion of the operation, the Mohel bandaged the penis, leaving the glans completely exposed.' According to Jewish tradition, if the head of the penis was left uncovered, the operation was invalid. When the penis was bandaged, the circumciser would drink a cup of wine, recite blessings, and then give the child his Jewish name. The father would also recite final blessings upon the child, and then the child would be handed over to the mother, following the same process used before the operation. $^{2}$

The Elijah's Chair

As mentioned in the previous section, the Jews would place a chair in the room where the circumcision was performed; this chair was called the Chair of Elijah. According to Jewish tradition, the chair had religious significance. The Jews believed that Elijah, the OT prophet, acted as the child's guardian during the circumcision. ${ }^{3}$

\footnotetext{
'Asheri, 36.

${ }^{2}$ Cohen, 51-55.

${ }^{3}$ Klein, 428.
} 
The belief in Elijah's presence and the need for an Elijah's Chair was probably based on the story about Elijah in $1 \mathrm{Kgs}$ 19:10. Under the leadership of the King of Israel, Ahab, and his wife, Jezebal, the Jews forsook the rite of circumcision and broke their Covenant with God. Elijah was upset about this and complained before the Lord that the Children of Israel had forsaken His covenant. In light of this biblical account, Wigoder states that the Jews believed that Elijah's spirit was present during the circumcision, ${ }^{1}$ and Bloch agrees that the Jews believed God had granted Elijah the privilege of attending all Jewish circumcision ceremonies. ${ }^{2}$ In order to signify the presence of Elijah, an extra chair was left empty in the room during circumcision, and this chair was considered sacred because Elijah's spirit was present to ensure that the child would fulfill the Covenant. ${ }^{3}$

\section{$\underline{\text { Rituals after Circumcision }}$}

According to Jewish custom, the time after the circumcision operation was characterized by festivals throughout the whole community. A special religious meal called Seudat Mitzwah was held immediately after the circumcision. During the meal, special prayers would be said for the child, his parents, and the circumciser. The Oxford Dictionary of the Jewish Religion states that special hymns and "blessings for the parents, the Sandek, the child, and the Mohel, as well as for the Advent of the

\footnotetext{
'Wigoder, 161.

${ }^{2}$ Bloch, 11 .

${ }^{3}$ Encyclopedia of the Jewish Religion, 1966 ed., s.v. "Circumcision."
} 
Messiah and the righteous priest," accompanied this meal which celebrated the renewal of the Old Covenant between God and His children.

\section{Circumcision in the New Testament}

The previous section of this chapter explored how the Jews viewed and practiced circumcision based on the OT. Circumcision not only fulfilled the covenant between God and the children of Israel (Gen 17), but it also marked a separation between the children of Israel and the Gentiles. The rite of circumcision physically and mentally distinguished the Jews from all the other nations around them. ${ }^{2}$ This section briefly examines the conflict over circumcision which arose during NT times between the Jews and the Early Christian church as a result of the New Covenant through Jesus Christ.

\section{The New Covenant}

By the time of Christ's birth, many of the Jewish people had lost the spirit of the Covenant. Although the actions and traditions of the Covenant were still performed and enforced by the religious leaders of Israel, the motives behind these actions had become selfish and corrupted. Nichol points out, "As a mark and reminder of this relationship [the Old Covenant], circumcision could have been a blessing to the Jews. But since they had so largely failed to live up to the essential requirements of

'Oxford Dictionary of the Jewish Religion (1997), s.v. "Circumcision."

${ }^{2}$ Dictionary of the Later New Testament and Its Developments (1997), S.v. "Circumcision." 
the covenant, circumcision became nothing more than an empty form." A New Covenant was necessary because the people had broken the original Covenant (Heb 8:8-9). For this reason, God sent His Son to die on Earth. Jesus' death on the cross sealed the New Covenant between God and His people through the shedding of innocent blood. In Rom 3:21-26, Paul clearly stated that this New Covenant made salvation available to everyone who has faith in Jesus.

The concept of righteousness by faith made the old Jewish regulations unnecessary for salvation and redemption. In making a New Covenant, God "made the first one [original Covenant] obsolete" (Heb 8:13). The Jewish people no longer needed to physically circumcise their children in order to remind them of the coming Messiah because this Messiah had already come. Instead, a spiritual circumcision which aimed at changing the hearts and souls of humanity became the new symbol of the New Covenant.

\section{Spiritual Circumcision}

The Jewish beliefs in the original Covenant about physical circumcision formed three obstacles for the Early Christian church. First of all, the Jewish converts to Christianity felt that circumcision was still necessary for salvation, and this was in direct disagreement with the New Covenant. The Jewish Christians required Gentile converts to Christianity (proselytes) to be circumcised in accordance with the Law of Moses, which stated that "all male children of the people of Israel as well as of all

\footnotetext{
1"'Acts-Ephesians," SDA Bible Commentary, ed. F.D. Nichol (Washington, DC: Review and Herald Pub. Assn., 1953-57), 6:493.
} 
male converts or proselytes" 1 must be circumcised. Paul did not condemn circumcision in and of itself; Acts 16:3 records that Paul circumcised Timothy. However, Paul spoke vigorously against the continued use of physical circumcision as a means of salvation. The book of Acts shows that some of the Christians felt it was necessary to circumcise Gentile converts "and to command them to keep the law of Moses" (Acts 15:5). By continuing to promote physical circumcision as necessary for salvation, the Jews ignored the promises and benefits of the New Covenant.

Physical circumcision not only caused the Jews to continue attempting to fulfill the original Covenant and to ignore the New Covenant. The Jews also felt that circumcision made them superior to other nations. During the NT period, the Jews boasted over the Gentiles, claiming that Jews were the only true children of God. The Jewish culture, which regarded itself as God's custodian of the Law, condemned the Gentiles as adulterous thieves not fit for salvation. In the NT, the Jews, including the Jewish converts to Christianity, regarded circumcision as "indispensable to salvation."2 Whitelaw asserts that, according to tradition among the Jewish Christians, "salvation was impossible without circumcision, that the way into the church of Christ led through Judaism, and that without submission to this carnal ordinance [circumcision], the spiritual blessings of the Gospel could not be enjoyed."3

'Millard J. Erickson, Christian Theology (Grand Rapids, MI: Baker Book House, 1983), 1036.

${ }^{2}$ Albert Barnes, Notes on the New Testament (Grand Rapids, MI: Baker Book House, 1953), 225.

${ }^{3}$ T. Whitelaw, Acts: The Preacher's Homiletic Commentary (New York: Funk and Wagnall's Co., 1943), 317. 
Finally, by forcing the Gentile proselytes to be circumcised when they converted to Christianity, the Jews were creating a pointless obstacle to their salvation. Paul's argument as presented in the NT was that circumcision and obedience to the law should not be imposed on the Gentiles as a requirement for Christianity and as a means of salvation. Paul wrote, "Therefore I judge that we should not trouble those among the Gentiles who are turning to God" (Acts 14:19). Paul's main interest was to bring freedom to the Gentiles from the rite and ceremonies which were a stumbling block to Christianity.

In the Old Testament, the rite of circumcision was performed externally on the physical flesh as a fulfillment of the Old Covenant. In the New Testament, the rite of circumcision became an internal change of heart which showed that person's acceptance of the New Covenant. According to Paul, Christians needed an inward circumcision of the heart: "Circumcision is circumcision of the heart, by the Spirit, not by the written code" (Rom 2:29).. Paul urged the Early Church to not rely on their physical circumcision to save them (Phil 3:3).

Paul's radical teaching about circumcision met with great opposition from the Jews. According to Josh 5, the Covenant between God and Abraham would not be effected if the children of Israel were not physically circumcised. The Jews believed that God's blessings would not be given to them if circumcision of the flesh was abandoned, and this conflicted with the message of the Christian church and the New Covenant. 
In Rom 2:28-29, Paul states that true circumcision, and what makes one a true Jew, is not a mark on the flesh or the outside appearance. Instead, true circumcision, as summarized by D.A. Carson, is "the circumcision of the heart, accompanied by the spirit."' The Bible points out that external circumcision was of no avail without circumcision of the heart, as indicated in the book of Deuteronomy: "And the Lord thy God will circumcise thine heart, and the heart of thy seed to love the Lord thy God with all thine heart and with all thy soul that thou mayest live" (Deut 30:6).

The Jews believed that the foundation of their faith was based upon circumcision. They believed that they were a chosen nation because they carried God's will. According to the Jews, circumcised Jews would definitely be saved in the day of judgment and did not need to worry about any punishment from God. However, Paul argued that circumcision was not an assurance of salvation. He believed that salvation from God can be obtained only by keeping the law. Therefore, Paul pointed out that the judgment of God on man is based upon what he has done according to the law (Rom 2:26). Arthur Lewis comments, "Paul therefore taught and believed that within the total number of Jews, there had always been a company of true Jews, all of those who were saved by faith and cleansed from within, having their hearts altered ('circumcised') to conform to the will of God."2

${ }^{1}$ D. A. Carson, New Bible Commentary, 21st Century (Chicago: InterVarsity Press, 1953), 1126.

${ }^{2}$ Arthur H. Lewis, "The New Birth under the Old Covenant," Evangelical Quarterly 56 (January 1984): 32. 
The important part to note for our purpose is that, in the New Testament, circumcision is not viewed as a means to salvation. Earnest Best rightly points out that "circumcision does not ensure salvation, and the Jew cannot depend on his privileges to escape the judgment of God." Geoffrey Wilson agrees with Best by adding that "the true circumcision is that of the heart which is renewed by the power of the Holy Spirit."

Therefore, what constitutes a true Jew is not the observance of the religious rites and ceremonies, but rather the righteousness of the inward heart. F.F. Bruce comments, "To be a Jew will do one good in the sight of God if he keeps the law of God. A Jew who breaks the law is not better than the Gentile." ${ }^{13}$ Thus we see that keeping the law is the sign of a true Jew, rather than thoughtless observance of the religious rites and rituals. Bruce further argues, "Conversely, a Gentile who keeps the law's requirements is as good in the sight of God as any law-abiding Jew." ${ }^{14}$ Therefore, although the Gentile believers did not possess the Law and were living by nature, according to the requirements of the law, their hearts and conscience bore testimony to the existence of a true covenant with the Lord. By keeping the requirements of the law, the uncircumcised Gentiles were regarded as circumcised in

\footnotetext{
'Earnest Best, The Letter of Paul to the Romans (Cambridge: Cambridge University Press, 1967), 33.

${ }^{2}$ Geoffrey B. Wilson, Romans (London: Hazell Watson \& Viney, 1976), 48.

${ }^{3}$ F.F. Bruce, Romans, Tyndale New Testament Commentaries (London: InterVarsity Press, 1985), 87.
}

${ }^{4}$ Ibid. 
God's sight. Paul states that if one breaks the law despite being circumcised physically, he becomes spiritually uncircumcised (Rom 2:25). The circumcised person is obliged to keep the law of God, and therefore circumcision is a legal requirement accompanied by the keeping of the whole law (Gal 5:3).

\section{Baptism}

In the Old Testament, the rite of circumcision indicated a removal of sin and a spiritual transformation of the heart. In contrast to physical circumcision, spiritual circumcision leaves no external mark which shows the world that a person has accepted the New Covenant. The book of Jeremiah states, "Circumcise yourselves to the Lord and take away the foreskins of your heart" (Jer 4:4). The Early Church discouraged the Jewish rite of physical circumcision (Acts 21:21, Gal 2:3-5, 5:2-6) and replaced it with a circumcision of the heart, baptism.

In the NT, baptism became a requirement for those joining Christianity. Louis Berkhof points out, "As circumcision was the sign of the covenant in the Old Testament, baptism is the sign in the New Testament. Baptism has been substituted for circumcision."' Some scholars believe that Jesus designated baptism as a substitute for circumcision in the New Testament. Millard Erickson points out, "Baptism has taken the place of circumcision as the initiatory rite into the covenant. It was Christ who made this substitution. He commissioned his disciples to go and

'Louis Berkhof, Systematic Theology (Grand Rapids, MI: William B. Eerdmans Pub. Co., 1953), 631-32. 
evangelize and baptize (Matt 28:19)."' Louis Berkhof further contends that "in the New Dispensation, baptism is divine authority substituted for circumcision as the initiatory sign and seal of the covenant of grace." ${ }^{2}$ George R. Beasley-Murray agrees with both Berkhof and that the NT Christian leaders viewed baptism as a substitute for circumcision, concluding that they "did away with the need of circumcision because it [baptism] signified the union of the believer with Christ, and in union with Him the old nature was sloughed off. A lesser circumcision has been replaced by a greater, the spiritual circumcision promised under the old covenant has become a reality under the New through baptism." ${ }^{3}$

\section{Conclusion}

In conclusion, the rite of circumcision originated among the Jews as part of the original Covenant between God and Abraham in Gen 17. Circumcision served as a physical action and symbol which granted each Jewish male membership into the Jewish community. The covenant between God and Abraham applied to all of Abraham's descendants, so circumcision continued throughout Jewish history, maintaining its spiritual significance until the time of the New Testament.

The NT clearly indicated that physical circumcision was no longer a part of salvation. Submission to physical circumcision no longer availed because every

'Erickson, 1094.

${ }^{2}$ Berkhof, 633.

${ }^{3}$ George R. Beasley-Murray, Baptism in the New Testament (London: McMillan, 1962), 315. 
Christian believer was circumcised in Christ through His free gift of salvation and His death on the cross. Therefore, every Christian needed to be spiritually circumcised to show renunciation of sin and transformation of the heart. Paul concluded that "in Christ Jesus neither circumcision availeth any thing, nor uncircumcision, but a new creature" (Gal 6:15). The change needed to come from the heart, and the only outward symbol of this change, baptism, would not be a means of salvation, but a sign of its acceptance. 


\section{CHAPTER 5}

\section{DANGERS OF TRADITIONAL CIRCUMCISION}

\section{$\underline{\text { Introduction }}$}

Chapter 3 examined the circumcision rituals and teachings of the Lomwe and Yao tribes. These two tribes encourage sexual promiscuity among the circumcised men and also emphasize the roles of ancestral spirits and witchcraft in illness and death. Chapter 4 presented the biblical teachings of physical circumcision, which was practiced by the Jews, and spiritual circumcision, which was accepted by the New Testament Christian church.

This chapter compares the Malawian and biblical circumcision traditions to point out the physical and moral dangers which the Malawian rituals cause. Although this chapter focuses on the harmful effects of the Malawian circumcision tradition, it is not completely negative about the traditional customs which have been practiced by the Malawians for centuries. Chapter 4 detailed how God clearly instituted physical circumcision in the Old Testament as a requirement which marked the Jews as people who belonged to God. Therefore, the actual cutting of the male foreskin, if done properly, does not contradict God's word. However, the teachings and beliefs which accompanied the Jewish circumcision were significantly different from certain Lomwe 
and Yao circumcision teachings which emphasize sexual promiscuity and worship of ancestral spirits.

The following sections examine the history of the AIDS virus in Malawi, the physiological damages which can be caused by traditional circumcision techniques, and the Lomwe and Yao cultural teachings which adversely affect the Malawian people.

\section{$\underline{\text { AIDS }}$}

Acquired Immunodeficiency Syndrome (AIDS) is a set of deadly symptoms which occur in someone who is infected by the Human Immunodeficiency Virus (HIV). ${ }^{\prime}$ In order to avoid confusion for non-scientific readers, this study uses the term AIDS to signify both HIV and AIDS.

\section{History}

Although many people in the scientific and medical professions have debated about the origin of AIDS, no hypothesis has been officially accepted. AIDS was first documented in $1959,{ }^{2}$ but it might have existed for a long time in an isolated geographical area of the world before its official discovery. Some researchers have credited the origins of AIDS to Africa, ${ }^{3}$ and others suggest that the virus might have

${ }^{1}$ Neil A. Campbell, Biology, $4^{\text {th }}$ ed. (Menlo Park, CA: Benjamin/Cummings Pub. Co., 1996), 873-875.

${ }^{2}$ Paul Wangai, Jr., "The Doctor Says . . .," Eastern Africa Division Outlook, April-June 1996, 12.

${ }^{3}$ Marcia Quackenbush and Pamela Sargent, Teaching AIDS (Santa Cruz, CA: Network Pub., 1986), 14. 
originated in America or the Soviet Union as a result of biological warfare. ${ }^{\prime}$ Hoffman and Grenz report that the spread of AIDS has been "extremely rapid in progression, worldwide in scope, and devastating in consequence. The story [of AIDS] will continue to grow as increasing numbers of persons are infected."2 As of 1999, an effective cure for AIDS has not been found.

\section{AIDS in Malawi}

AIDS was very widespread around the world by the early 1980s, and in 1985, the first case of AIDS in Malawi was diagnosed. Despite public awareness of AIDS in Malawi through the use of media, religious organizations, and community education programs, AIDS has spread at a very alarming rate. In 1992, the government of Malawi collected data regarding AIDS from various hospitals in the twenty-four districts of Malawi. The results of this study indicated that 23 percent of the Malawian people between the ages of $15-49$ years who lived in urban areas and 8 percent of people in the same age group who lived in rural areas had contracted AIDS, a total number of 19,194 Malawians. ${ }^{3}$ Also in 1992, the AIDS secretariat in Malawi estimated that between 700,000 to 1.1 million Malawians would probably have AIDS by the end of 1996 . This estimate would mean that over 10 percent of the entire

'Robert E. Lee, AIDS in America (New York: Whitson Pub. Co., 1987), 10.

${ }^{2}$ Wendel W. Hoffman and Stanley Grenz, AIDS Ministry in the Midst of an Epidemic (Grand Rapids, MI: Baker Book House, 1990), 61.

${ }^{3}$ Government of Malawi and the United Nations in Malawi, Situational Analysis of Poverty in Malawi (Lilongwe, Malawi: Author, 1993), 182. 
Malawian population (10 million people) could be infected with the incurable AIDS disease by $1996 .{ }^{1}$

The AIDS disease has affected people from every tribe, area, and religious faith in Malawi, regardless of their economic or educational background. The economic resources of Malawi have been severely drained by the many costs which are associated with AIDS: care for orphans and widows, use of land areas for burials instead of farming or building, and the use of trees to build wooden coffins. Also, the increased number of deaths in Malawi has diminished the potential number of childbirths, which in turn reduces the future development potential of the country.

Paul Wangai strongly outlined the danger which AIDS presents to Africa and the world: "At present, HIV [AIDS] is present in every country of the world. It affects all people regardless of color, race, country, sex, education, age or any other aspect. Anyone can get HIV given the right circumstances."2 AIDS is especially threatening because, at the present, there is no cure. Though recent developments indicate a possible vaccine for curing AIDS, there is no guarantee that one will be found anytime soon. The only way to eliminate AIDS is to stop its transmission. ${ }^{3}$ 1992), 2.

'AIDS Secretariat, Malawi AIDS Control Program (Lilongwe, Malawi: Author, ${ }^{2}$ Wangai, 12.

${ }^{3}$ Ibid. 
Transmission of AIDS

AIDS is not transmitted through general contact with someone who has AIDS, such as shaking hands, eating from the same dish, drinking from the same glass, or using the same bathroom. However, AIDS can be transmitted if a person comes in contact with the bodily fluids of an infected person. Several studies have revealed that AIDS is mainly transmitted from one person to another in two ways; these two transmission methods, along with the Lomwe and Yao circumcision practices which promote these methods, are examined below.

\section{$\underline{\text { Sexual Intercourse }}$}

One method of AIDS transmission is by sexual intercourse with an infected person. The secretions which are released by the male and female sexual organs during sexual arousal can carry AIDS. ${ }^{\prime}$ During any unprotected sexual behavior, there is the possibility that AIDS may be transferred to another individual by the exchange of fluids through "tissue in the vagina, penis, rectum, or possibly the mouth, and through cuts or sores." ${ }^{2}$ Kenneth R. Overberg clarifies that during any sexual contact, "including heterosexual and homosexual intercourse, HIV [AIDS] is then spread when certain body fluids are transferred from an infected person in semen, vaginal fluids,

\footnotetext{
'Warren Colman, Understanding and Preventing AIDS (Chicago: Children's Press, 1988), 50.

${ }^{2}$ Marcus Alred Harris, "A Model for Pastoral Nurture and Care to AfricanAmerican Persons Who Are HIV Infected or Living with AIDS" (D.Min. dissertation, Andrews University, 1995), 14.
} 
etc." Howard Libman and Robert A. Witzburg point out that transmission of AIDS during heterosexual intercourse primarily travels from the male to the female, "which appears to be a more efficient route than from female to male."2 Even "respectable and socially-acceptable sexual relationships"3 can transmit AIDS through "direct contact with the . . body secretions of a person with AIDS." ${ }^{4}$

The Lomwe and Yao circumcision teachings directly promote sexual promiscuity among the initiates while they are out in the bush. The boys are given instructions about sexual techniques during the ceremony. Since the ceremony is a passage from boyhood into manhood, the boys are expected to demonstrate their new maturity not only by behaving respectfully and taking up adult responsibilities, but also by engaging in sexual activities. As soon as the ceremonies are over, the initiates begin to look for girls of their age in order to have sexual intercourse and thus prove their manhood. The chances of AIDS transmission during these hundreds of unplanned sexual relations among young, uninformed Lomwe and Yao teens are tremendously high.

\footnotetext{
${ }^{1}$ Kenneth R. Overberg, AIDS Ethics and Religion (New York: Orbis Books, 1994), 2.

${ }^{2}$ Howard Libman and Robert A. Witzburg, HIV Infection: A Clinical Manual (Boston: Little Brown and Co., 1993), 8.

${ }^{3}$ George Jacobs and Joseph Kerrin, What We Need to Know About AIDS Now (Woods Hole, MA: Cromlech Books, 1997), 32.

${ }^{4}$ Seth C. Kalichman, Understanding AIDS (Washington, DC: American Psychological Assn., 1995), 31.
} 
The traditional circumcision teachings about manhood and sexuality continue to unwittingly encourage the spread of AIDS, and the circumcision teachings about witchcraft and ancestral spirits indirectly blind the Malawian people to the danger of AIDS which faces them. AIDS, a very ravaging and deadly disease which has no externally obvious cause, is often considered by Malawians to be the result of a witch's spell or the anger of ancestral spirits. Even Malawian Christians are influenced by the traditional beliefs because the potency and incurability of AIDS creates uncertainties that challenge their previously held Christian beliefs. ${ }^{1}$ The Malawian people cannot acknowledge and understand the relationship between AIDS and sex until the Christian churches of Malawi address the cultural teachings about witchcraft and ancestral spirits.

The Jewish circumcision rituals did not contain any teachings for the infant circumcised boy, but the act of circumcision symbolized a commitment to God. Circumcision did not make a Jewish boy into a man; the actual entry to manhood among the Jews was a boy's twelfth birthday, but even this milestone did not require the boy to engage in sexual activity in order to prove his manhood. If AIDS had been present during Bible times, the biblical method of physical circumcision would not have assisted in AIDS transmission. By following the Bible's example and eliminating the cultural teachings which relate sexual promiscuity and maturity, the Malawian people could drastically reduce the spread of AIDS in their country.

\footnotetext{
182.

'A. Greeley, The Denomination Society (Glenview, IL: Scott Foresman, 1972),
} 


\section{Shared Surgical Equipment}

Numerous studies have revealed that the second method by which AIDS is transmitted is the sharing of needles, razor blades, or syringes. AIDS transmission by syringes and needles is especially common among people who use drugs by injection. Blood, which also carries the AIDS virus, can remain on a needle or syringe after it is used, and simply flushing a needle with water before using it again may not be enough to prevent transmittal of AIDS. The American Red Cross warns:

The CDC strongly asserts that flushing or sterilization of syringes (needles) used by IV drug users may not absolutely deactivate HIV in the syringe. Therefore, during presentations, instructors are to advise listeners that all sharing of syringes is unsafe, and that a sterile syringe should be used every time. If syringes are shared, the CDC advises that multiple flushing occur using full-strength bleach and that the bleach remain in the syringe for at least 30 seconds. This procedure does not guarantee that the syringe will be completely safe but that it could cut down on the number of HIV infections. ${ }^{1}$

Sharing syringes, needles, and razor blades for tattooing, injecting, and other actions are all ways in which AIDS can be transmitted. ${ }^{2}$

Obviously, the Lomwe and Yao circumcision rituals, which utilize just one razor blade or knife in all of the operations during a ritual, can encourage AIDS transmittal. By using an unsterilized razor blade or knife during the surgical operation, there is a definite possibility of AIDS transmission which can only be prevented with proper surgical equipment and training. However, the Lomwe and Yao believe that

\footnotetext{
${ }^{1}$ American Red Cross, "Health and Safety Instructor News," pamphlet, quoted in Marcus Eldred Harris, "A Model for Pastoral Nurture and Care to African American Persons Who Are HIV Infected or Living with Aids" (D.Min dissertation, Andrews University, 1995), 16.

${ }^{2}$ Quackenbush and Sargent, 10.
} 
any male who is circumcised in a hospital is not truly circumcised, and this belief prevents the people from modernizing the current equipment and techniques of the circumcision rituals.

The Jewish circumcision rituals involved sharp stones (Exod 4:24-26), knives, and other cutting instruments. ${ }^{\prime}$ Although all of these cutting implements could transmit AIDS-infested blood, the Jewish circumcision ceremony involved only one child. Therefore, even if the child had AIDS, no other boy would be infected by sharing the cutting tool. In modern times, the Jews have integrated Jewish doctors into the circumcision ceremonies in order to protect the child from harm while also fulfilling the Old Testament covenant. ${ }^{2}$ Furthermore, the New Testament concept of circumcision, circumcision of the soul, was a purely spiritual concept. This method would also have removed all chances of AIDS transmission through shared surgical items.

The biblical physical and spiritual circumcision rites avoided both of the possible methods of AIDS transmission: sexual intercourse and sharing of surgical items. However, as the following section examines, both the Jewish and Malawian physical circumcision rituals are capable of causing physiological damage during the operation.

'Klein, 422.

${ }^{2}$ Ibid., 427. 


\section{Physiological Damage}

Unless performed by a trained surgeon, a circumcision operation can cause physiological damage to the sexual organs of the circumcision candidates. The circumcision procedure requires the circumciser to have a medical knowledge of the structure of the penis in order to avoid complications such as "blood loss, infection, and mechanical or structural abnormalities." Ronald Goldman agrees that the risks in circumcision during the surgical operation include "surgical trauma and ulceration or narrowing of the opening of the urethra (Meatal ulceration/Meatal stenosis)."2

Because of personal embarrassment and social stigma, Malawian circumcised men who suffer physical damage during traditional circumcisions do not usually report the damage or attempt to seek treatment for it. The following information regarding the circumcision surgical procedure of Malawian rituals was provided by a circumcised man who wished to remain anonymous because of the physiological damage which he sustained during a traditional circumcision operation.

The surgical risks and complications present in the traditional Malawian circumcision rituals are increased by a lack of proper sanitation and equipment. However, a greater danger in the surgical operation is due to the lack of training among the traditional tribal circumcisers. The circumcisers are not educated in the physical development and structure of the penis. Therefore, some Lomwe and Yao

\footnotetext{
'Thomas J. Ritter and George C. Denniston, Say No to Circumcision (Aptos, CA: Hourglass Book Pub., 1996), 5-2.

${ }^{2}$ Goldman, Circumcision: Hidden Trauma, 208.
} 
circumcisions result in excessive or forced cutting of the foreskin which can lead to hemorrhaging and undue pain during an erection. ${ }^{1}$ George C. Denniston points out that the penis is an extremely sensitive organ, and he claims that forcibly retracting the skin of the penis is literally like "skinning the penis alive.""

The physiological damages which can be caused by Malawian circumcision can also be caused by Jewish circumcision. The Old Testament Jews did not have any medical training or knowledge about the penile structure and development. It is very possible that many Jewish boys suffered minor or major structural or functional damage during the circumcisions in biblical time, as some Malawians do today, even though the mohel (Jewish circumciser) was intensively trained for his task. ${ }^{3}$ However, the Jewish culture now allows for the actual circumcision to be conducted by a trained medical professional. In stark contrast to the modernized Jewish attitude, the Lomwe and Yao people still ridicule any male from their tribes who is circumcised in a hospital by a medical specialist. The tribal community regards such a person as an uncircumcised child (

\section{Moral Damage}

The traditional Malawian circumcision rituals can have serious physical effects on the people of Malawi. However, certain teachings which accompany these rituals

\section{'Anonymous.}

${ }^{2}$ George C. Denniston, “First, Do No Harm!" Journal of Free Thought and Inquiry 1 (July/August 1989): 36.

${ }^{3}$ Cohen, 13 . 
actually cause more harm than the physiological damage of poor circumcision operations and the transmission of AIDS through the use of shared, unsterilized surgical tools. As previously mentioned, the Lomwe and Yao cultural teachings which encourage sexual promiscuity among the circumcised boys not only promote AIDS transmission but also contradict the biblical teachings about the sanctity of marriage. Furthermore, the traditional beliefs in witchcraft and ancestral spirits bind the Malawian people into continuing the harmful rituals and teachings of traditional circumcision.

While proper medical training and equipment alone could help to minimize or eliminate the physiological damage and AIDS transmission by shared blades, the dual physical and moral effects of the traditional circumcision teachings make a more refined approach necessary. The government of Malawi is not capable of providing suitable substitutes for the traditional beliefs; this duty falls to the Christian churches in Malawi, including the Seventh-day Adventist church. The SDA church can provide the Malawian people with an understanding of the state of the dead in order to eliminate the tribal fears of witches and ancestral spirits. Once these fears are addressed, the Lomwe and Yao people would feel able to modify the circumcision rituals to allow medical training and equipment into their ceremonies. The Christian churches can also teach the people about the sanctity of sex within marriage in order to reduce sexual promiscuity and the traditional teachings which encourage it.

It is important to note that not all of the Lomwe and Yao circumcision instructions are bad. Some of the teachings which the boys receive during the 
circumcision ceremony are morally beneficial to them. One of the main themes of the circumcision teachings is respect for parents and elderly people. Malawian parents are afraid that their children will lose respect for them and not take responsibility for the elderly people of the community in the future. Among the modern Lomwe and Yao cultures, some people of the younger generations have abandoned the traditional circumcision initiation, and the tribal communities blame these people for the increase in misbehavior among the youth.

In response to the increased misbehavior among the youth, the government and the Christian churches of Malawi must work together to show the people a proper way to instruct their children about social and family values. Chapter 6 examines possible actions the government and the Christian churches can use to accomplish this large but important task.

\section{$\underline{\text { Conclusion }}$}

The Lomwe and Yao rites of circumcision cause physical and moral damage to the people of Malawi. The teachings about sexual promiscuity and ancestral spirit worship have increased the spread of AIDS in Malawi and maintained the people's motivation for carrying out the rites. In contrast to the Malawian circumcision teachings, the Jews did not teach their children to engage in sexual promiscuity. The Jewish circumcision rites were carried out as a symbol of worship to God, instead of as a way to appease the ancestral spirits. Finally, the Jewish circumcision avoided AIDS transmission by only circumcising one boy at a time. 
The Malawian cultural disapproval of medical assistance for circumcision has caused more AIDS transmission and physiological damage through the untrained circumcisions. On the other hand, the circumcision initiation also teaches the boys about social respect and responsibility in the Malawian culture. The Malawian government and the Christian churches in Malawi must make a joint effort to stop the physical and moral damages of this ritual while preserving the cultural standards of respect and responsibility by the youth for their parents. Chapter 6 provides recommendations, based on the findings of this study, which can help the government and churches of Malawi to accomplish this effort. 
CHAPTER 6

\section{SUMMARY AND RECOMMENDATIONS}

\section{$\underline{\text { Summary }}$}

The goal of this study was to study the rituals and teachings which compose the traditional circumcisions of the Lomwe and Yao tribes in the Malawian society, focusing on their physical, moral, and spiritual damages. By understanding the circumcision practices, the SDA church and the government of Malawi can work together to provide biblical and medical solutions to the problems inherent in these practices.

Following a brief introduction to the problem in chapter 1 , the study examines the history of Malawian culture, detailing the entrance of various tribes and also of Christian missionaries into the country. The circumcision rituals and teachings of the two Malawian tribes which currently practice circumcision, the Lomwe and Yao tribes, are described individually and also compared to each other. The teachings about ancestral spirits and witchcraft, which strengthen the cultural dependence on these practices, are also examined.

Following the examination of the traditional circumcision practices in Malawi, the biblical origin and usage of circumcision illuminates the dangers of traditional circumcision. God's institution of physical circumcision as a symbol and seal of His 
covenant with Israel contrasts strongly with the Malawian usage of circumcision. The Jewish circumcision ritual, with its emphasis on obedience to God, is detailed before the study turns to the role of circumcision under the New Covenant. Spiritual circumcision, a circumcision of the heart and soul instead of the flesh, takes the place of physical circumcision for the New Testament Christians.

Finally, the comparison of Malawian and biblical circumcision highlights the physical, moral, and spiritual dangers which face the people of Malawi. The spread of AIDS and the increase of unwed pregnancies, along with physiological damage caused by untrained circumcision, is very prevalent in Malawi. Furthermore, the circumcision teachings which encourage sexual promiscuity and belief in ancestral spirits morally and spiritually contradict Christianity.

\section{Conclusions}

The teachings and techniques of traditional circumcision among the Lomwe and Yao tribes were not designed to harm the Malawian culture. The teachings about witchcraft, ancestral spirits, and sexual activity were not consciously created by the Malawian people in order to destroy their society from the inside. These traditional rites have persisted in Malawi for many generations, but the long duration of a cultural habit cannot be used as proof that said habit is good for the society. As Hiebert warns, culture is free from "value judgments, such as good or bad." In order to

\footnotetext{
'Paul G.Hiebert, Cultural Anthropology (Philadelphia: J.B. Lippincott Co., 1976), 25.
} 
determine the true value of a cultural pattern, the results of that pattern must be measured against the results of God's pattern.

By comparing the Malawian and biblical circumcision rituals, it is apparent that the Jews who practiced circumcision acted in accordance with God's will. The Jews were not innocent of any wrongdoing in obeying God, but the practice of the circumcision rite did not weaken their relationship with God or lead to sexual promiscuity or disease among the Jews. On the other hand, the Lomwe and Yao circumcision rites have contributed to the increase of AIDS in Malawi and have created moral and spiritual conflict between the Malawian people and the SDA church. Since both the Jews and the Malawian tribes practiced physical circumcision, the abolition of the circumcision act does not appear to be the solution to resolving the moral, spiritual, and physical damage in Malawi. Instead, the teachings which accompany the Lomwe and Yao circumcisions must be addressed by the SDA church and the Malawian government for the sake of the Malawian people.

Since the SDA church cannot force the Malawian people to accept its beliefs as their own, this study cannot support the elimination of traditional circumcision. Since the dangers of traditional circumcision lie within the Malawian society, the response and correction of those dangers must also come from inside the society. The SDA church can participate in the process of equipping the Lomwe and Yao people to understand and modify the circumcision rituals and teachings, but those modifications must originate in and reflect the Malawian culture. By designing and maintaining contextualized methods for helping the Malawian people to understand the sanctity of 
marriage, the state of the dead, and other important beliefs, the SDA church can act as a bearer of spiritual light. However, the Malawian people will need to accept that light and utilize it on their own before any effectual changes can be made in the traditional concepts and teachings of the circumcision rite of passage.

The role of circumcision in the Lomwe and Yao cultures is very complex and important. The destructive aspects of the circumcision rites, such the teachings about sexual promiscuity and the lack of proper equipment and training, are balanced by the positive benefits, such as improved family relationships and social responsibility. In order for the Malawian people to modify this complex cultural institution in order to eliminate its negative aspects without removing the positive ones, the people must first feel a need for change. The SDA church can follow a process to bring about that sense of need in Malawi, which will then empower the people to actively search for alternatives to the dangerous aspects of circumcision. The following section outlines the important steps which the SDA church and the Malawian people must follow in order for change to truly take place within the Malawian culture.

\section{Cultural Improvement}

According to Donald K. Smith, change cannot take place in a culture until that culture feels a need for change. ${ }^{1}$ The process of converting a need for change into action can be broken down into six steps: Awareness, Interest, Consideration, Choice,

\footnotetext{
'Donald K. Smith, Creating Understanding (Grand Rapids, MI: Zondervan, 1992), 334.
} 
Action, and Readjustment. These six stages, as explained by Smith, ${ }^{1}$ and their application to the need for change in the Malawian circumcision rituals are briefly outlined below.

\section{$\underline{\text { Awareness }}$}

In this first stage, awareness does not involve a knowledge of good and evil. Instead, it simply requires that the targets for change, which in this study is the Lomwe and Yao tribes, become aware of alternatives to the current cultural solutions for their needs. The SDA church must not initially claim that the Lomwe and Yao circumcision rituals are wrong; instead, the church must present these tribes with alternatives to the harmful teachings and actions within those rituals.

\section{$\underline{\text { Interest }}$}

This stage requires the target group to be interested in any of the alternatives presented in the first stage. If the Malawian people are not attracted to any of the spiritual or physical alternatives which the SDA church offers, such as freedom from fear of witches and ancestral spirits and a decreased chance of AIDS transmission, then the church cannot hope to catalyze an internal change within the Malawian culture.

\section{$\underline{\text { Consideration }}$}

This stage places the responsibility for change into the hands of the target group. From this point forward, the target group is responsible for continuing the

'Ibid., 334-335. 
change process. Once it has realized its interest in one or more of the alternatives, the target group must now weigh those attractive alternatives to determine if the benefits are sufficient enough to merit cultural change. The Malawian people cannot be forced to accept any alternatives which the SDA church presents to them; they must internally decide whether the offered alternatives or modifications to circumcision are more valuable than the current traditional rite of passage.

Choice

This step calls for the first direct action on the part of the target group. Assuming that the target group has decided that one or more alternatives from step one is worthwhile, the group must now choose which alternative to pursue. On the other hand, this step can also be the final step in the change process: if the target group decides that none of the alternatives are valuable to them, then they can choose to reject all of the alternatives, effectively terminating any cultural change at that time. The SDA church must be willing to respect the choice of the Malawian people in this step, because the process of change is now under their control.

Action

If the target group chooses to pursue an alternative, this step requires them to make this decision visible. While the choice step takes place within the group's internal decision process, the action step requires external implementation of that decision. As Smith paraphrases, the action step "is the evidence of things not seen, the 
unseen choice expressed in visible action." It is at this stage when the Malawian people can permit the SDA church to participate in the necessary actions for implementing the desired alternatives for circumcision teachings and rituals.

\section{$\underline{\text { Readjustment }}$}

Smith warns that "efforts to bring change cannot be concerned primarily with the act of choice, as if the process were complete once the choice is made. The action growing out of the choice may well require major readjustments, not all of which will be immediately apparent." 2 The SDA church cannot assume that, once the Lomwe and Yao people decide to modify the circumcision rituals, everything will run smoothly. The importance of circumcision to the Lomwe and Yao cultures ensures that any changes in that rite will have consequences. These consequences may vary in duration and impact, but none of them can be ignored or minimized. The SDA church in Malawi must be willing to continue helping the Malawian people to address the harmful aspects of traditional circumcision rites long after the Malawian people realize their need for change.

\section{$\underline{\text { Recommendations }}$}

The traditional Lomwe and Yao circumcision rituals affect the beliefs and lifestyles of both Christians and non-Christians in Malawi. The AIDS epidemic in Malawi is aided by the traditional support of sexual promiscuity, and this has harmed

${ }^{1}$ Ibid., 324.

${ }^{2}$ Ibid., 325. 
the entire Malawian population. The complex nature of this situation cannot be resolved unless the Malawian SDA churches and the Malawian government make a joint effort to solve this problem.

The issues of traditional circumcision must be addressed in a Christian manner and with a loving spirit. The traditional unbiblical practices will continue to affect the church and the Malawian people until they are replaced through Christian influence, using Scripture and the working of the Holy Spirit. It is important that every church member, pastor, and Field or Union leader acknowledge and depend on the power of the Holy Spirit to help God's people. Jesus Christ promised His disciples that the Holy Spirit would be a comforter to them and would guide God's people to find solutions to pressing issues which they cannot solve on their own. The Bible states that "the Holy Ghost . . . shall teach you all things" (John 14:15). The power of the Holy Spirit sustained the early church and helped it to develop into modern-day Christianity, and today's Christians in Malawi can still depend on the Holy Spirit to assist them in following God and discovering His answers for the issue of traditional circumcision.

The purpose of these recommendations is not to immediately eliminate the act of circumcision. The process of changing a culture requires cultural outsiders to be "aware of the cultural patterns and processes of the culture ... [and to] work with or in terms of these patterns and processes to bring about the changes they seek." The 353.

'Charles H. Kraft, Christianity in Culture (Maryknoll, NY: Orbis Books, 1979), 
goal of this study's suggestions is to encourage cooperation among the Malawian culture, the SDA church, and the Malawian government in order to stem the harmful results of circumcision teachings and practices.

In a similar way, these recommendations do not attempt to force a Christian lifestyle or culture upon the Malawian people. There would be no benefit to the people of Malawi if they were to "convert to the culture of [the SDA church] without developing a saving relationship with God." 1 These recommendations attempt to enlighten the people about the dangerous aspects of circumcision rituals and teachings, such as increased sexual promiscuity and AIDS transmission, and then to present them with contextualized Christian values and practices which will maintain the principles of the gospel while also strengthening and supporting the Malawian culture.

Contextualization is a very complex topic which affects the spread of the gospel to other cultures. While contextualization is an area worthy of study on its own, the concept can be explained in a brief manner: contextualization is "an attempt to communicate the gospel in a way that is faithful to its essence, understandable to those to whom it is presented, and relevant to their lives." ${ }^{2}$ In order for the following recommendations to be the most effective and helpful to the Malawian people, the SDA church must use contextualization to reach out to its Malawian host culture. The following recommendations can deal with the painful and harmful practice of

${ }^{1}$ Ibid., 340.

${ }^{2}$ Alan Neely, Christian Mission: A Case Study Approach (Maryknoll, NY: Orbis Books, 1995), 9. 
Malawian circumcision rituals and teachings only if the Malawi culture is not ignored or supplanted.

The indigenous people should be allowed to resolve these cultural issues within their own cultural context. The process of finding and implementing solutions to this problem should not be over-influenced by Westerners, who may not fully understand the reasons and implications behind these cultural practices. Contextualization of all solutions to the problems of circumcision is crucial in order for Malawi to weed out the dangers among this cultural tradition.

The following recommendations are based on the information which I have collected and examined during this study. My recommendations focus on different groups in the Seventh-day Adventist church (local congregations, local pastors, local Field leaders, and leaders of the Malawi Union of SDAs) and also on the Malawi Government Ministry of Health. Once the government and the SDA churches of Malawi work together to educate the people about the physical and moral dangers of the traditional circumcision, the native Malawians should be instructed to take responsibility for these cultural problems. The people of Malawi should be entrusted to find culturally appropriate solutions to their problems. If the government or the churches force any solutions, including the following recommendations, upon the Malawians, there will be no genuine change among the people. The circumcision practices and teachings will become only more secretive and exclusive, and this will prevent the government and the churches from continuing to reach out to the people and help them to change their dangerous practices and beliefs. 


\section{Local Congregations}

In order to address the societal issues that have arisen from the traditional circumcision practiced in Malawi, the SDA church members who live in areas which practice traditional circumcision should participate in the process of formulation of culturally acceptable practices that are not in conflict with the biblical teachings. If the local believers, along with the members of the community, are allowed to participate in decision-making on these traditional issues, they will be willing to support the eventual changes. The local church members are qualified to search for and present valid solutions to the problem because they are much closer to the issues than pastors or Field and Union leaders. The local members are the ones who are directly affected by the issues of circumcision practices and teachings.

These issues can be resolved only if the church believers are united and dependent on Jesus and the Holy Spirit. The following recommendations for the local church congregation require unity of purpose among the church members in order to succeed.

1. Under the encouragement of the Field leaders, the local congregations should discuss the issues surrounding traditional circumcision and develop functional substitutes for the traditional circumcision practices and rituals which are contrary to biblical teachings (see Appendix).

2. The local congregations should agree to set aside a special day every quarter, preferably a Sabbath, on which they will pray and fast to ask the Holy Spirit to guide them in dealing with the traditional circumcision issues. 
3. The local congregations should pray for the church members who are currently being directly affected by the traditional customs. The church members should believe that each church member can "do all through Christ" who is beyond the evil forces and who gives them strength to overcome (Phil 4:13).

4. The local church members should conduct Bible studies in their homes. These Bible studies should address the traditional circumcision practices, using Scripture to determine which of the practices and teachings are unbiblical. This will help the members to understand why certain practices and teachings must be changed and to spread this understanding to people who are being affected by these issues.

\section{Local Pastors}

The SDA church members and leaders must be submissive to the guidance of the Holy Spirit in order to develop meaningful biblical substitutes for the unbiblical circumcision practices and teachings. The pastors of SDA churches in the Malawian communities which practice traditional circumcision must encourage and empower their church members to learn about and understand the circumcision practices and teachings. The pastors must guide the members in their education about the circumcision practices while simultaneously allowing them to devise biblical solutions which will be culturally appropriate for them.

1. The local church pastors should conduct seminars to teach the church members about the cultural and spiritual issues surrounding traditional circumcision. Such teachings should include information about the rite of circumcision in the light of the Old and New Testaments. 
2. The pastors should meet with local church members once every quarter to discuss the aspects of the traditional circumcision which are contrary to the Scripture and which also present health hazards.

3. The local SDA pastors should not pretend that their church has the only proper answers to all of the problems surrounding traditional circumcision. The pastors should encourage their church to work jointly with community leaders and qualified medical personnel, regardless of their personal religious affiliations. By working with everyone who wants to help the people of Malawi, the SDA church can spread its influence and reach out to previously unreached sectors of Malawi.

4. The local pastors should preach sermons which will help their church members to understand the traditional circumcision practices and customs. The pastors must promote spiritual growth for the church members and help them to avoid syncretism of traditional and Christian beliefs by emphasizing the importance and benefits of following God's Word.

5. Local pastors should encourage and teach their congregations to conduct Bible studies. They should also assist their church members in preparing Bible study lessons which will equip the congregation with spiritual information which will help them to deal properly with the traditional circumcision practices and teachings.

6. The local pastors and congregations should discuss ways to evangelize the circumcision initiates before, during, and after the traditional rituals. Uncircumcised boys and their parents could be educated about the dangers of traditional circumcision. Traditionally circumcised Christian males could attend the circumcisions in order to 
better understand the ceremonies and teachings, which would help the church to provide appropriate assistance for the circumcised boys. The church should also minister to the boys who have been circumcised by showing them the dangers of the circumcision teachings and presenting them with the biblical beliefs about sex, death, and other topics.

\section{Field Leaders}

The Field level of leadership for the SDA church should take a position of encouraging and monitoring local efforts to solve the issues of traditional circumcision. The Field leaders can use their many contacts and resources to provide the pastors and congregations with the means to discover and implement solutions to the dangers presented by the circumcision practices and teachings.

1. The SDA church leaders at the Field level should be careful in dealing with the issues regarding circumcision practices. The leaders should be open to discussion with the local church members, allowing the members to share their views about circumcision.

2. Because of the seriousness of the issues involved during the traditional circumcisions, the Field leaders should form a subcommittee composed of lay representatives and pastors. This committee should discuss and monitor issues about circumcision practices and teachings on a quarterly basis and report its findings to the Field leaders.

3. The church Field leaders must be willing to adopt suggestions made by both Christian and non-Christian local people, as long as the suggestions do not dilute SDA 
Christian standards. By involving non-Christians in the process of changing the harmful cultural practices of traditional circumcision, the church can reach these people with the message of God's love.

4. The church Field leaders should prepare Bible study lessons and sermon materials on topics related to circumcision in order to equip the local pastors and the laity with useful information.

5. The Field leaders should make the people aware of the need for substitutes to the traditional circumcision practices. The Field leaders can accomplish this task during the Field Sessions and the Worker's Meetings.

6. The SDA Field leaders can encourage the church pastors to include Bible studies about circumcision practices and teachings when they present Bible studies at the camp meetings. The Field leaders should also encourage the pastors to involve their congregations in group discussions about traditional circumcision and topics which are related to this ritual, such as witchcraft, spiritualism, the state of the dead, and the sanctity of marriage.

7. The Field leadership should instruct the local pastors and church members to avoid setting heavy penalties, such as disfellowship, exclusion from communion, or censure, upon those church members who may wish to continue practicing circumcision in the traditional manner.

8. In order to solve the complex issue of traditional circumcision without offending the people who practice traditional circumcision, the Field leaders should 
encourage the pastors and church members to continually unite in prayer and seek the guidance of the Holy Spirit on these matters.

9. The church Field leaders should be open to guidance by the Holy Spirit. This might require them to turn down human suggestions or take unusual steps in order to fulfill the will of God as revealed by the Holy Spirit.

\section{Union Leaders}

The Union leadership of the SDA church should strive to provide a favorable atmosphere throughout the SDA churches of Malawi for contextualized solutions to the problem of traditional circumcision. The Union leaders are responsible for approving suggestions from the Field level, and they must allow the Field leaders and their church pastors and congregations to explore possible alternatives for traditional circumcision practices and teachings.

1. The Union leaders should develop guidelines which they can use when considering suggestions made by the local congregations, pastors, and non-Christian community members. These guidelines should not replace or stifle any viable solutions; rather, they should complement and assist these suggestions in order to benefit the people who are being directly affected by the circumcision traditions.

2. The Union Education Department should encourage the Lake View Ministerial School in Malawi to teach their pastors-in-training about the cultural issues, customs, and beliefs which are related to the circumcision rituals.

3. The Union leaders should encourage the Malamulo Seventh-day Adventist School to conduct seminars on traditional circumcision for the local Lomwe and Yao people. 
4. The Union leadership should enlist SDA medical doctors to present lectures on traditional circumcision in relation to AIDS transmission and surgical risks. These lectures should be presented to the SDA pastors during the Union Worker's Meetings, and adequate time should be dedicated for discussions and questions about the cultural issues. These seminars and discussions would attempt to find possible solutions to the cultural and traditional concerns surrounding circumcision in Malawi.

\section{Government of Malawi}

The SDA church cannot solve the problems of traditional circumcision on its own. The community members and other denominations must cooperate with the SDA church, combining their resources and knowledge to help the people of Malawi. However, in order to protect the Malawian people from the spread of AIDS in Malawi, the Malawian government must also participate in the efforts of the churches and communities. The following recommendations should be carried out by the Malawian government in order to educate the people of Malawi:

1. The Malawian government should use the Ministry of Health to educate the people of Malawi about the dangers of AIDS and its relation to the traditional circumcision rituals and to the cultural beliefs about sexual promiscuity.

2. The Ministry of Health should develop an informative program to encourage the people of Malawi to circumcise their children in hospitals instead of in the deep bush areas.

3. The Malawi government should use its legal powers to restrict the traditional customs which are harming the people of Malawi. Certain Malawian customs increase 
the sexual transmission of AIDS, such as Kuchotsa Infa, the custom in which a man has sexual relations with the wife of his deceased brother as a means of ritual cleansing, and Kulowa Chokolo, the custom in which a man marries his deceased brother's widow in order to support her. These traditions increase the transmittal of AIDS throughout Malawi. The unhygienic surgical procedures of the traditional circumcisions also increase the spread of AIDS. The government of Malawi could create legislation which would restrict these practices. However, the government would need to work together with the churches in order to avoid simply forcing the Malawians to change their traditions. If the churches educate the people about the dangers of these traditions, the people would be more likely to obey any government regulations about the traditional practices.

4. The government should work with the religious organizations of Malawi to fight against the traditional practices and customs which lead to harmful behaviors. The government can encourage and assist the churches of Malawi to speak against sexual promiscuity and unhygienic surgical procedures, which lead to increased AIDS transmission and death in Malawi.

\section{Conclusion}

These recommendations do not provide every possible solution to the problems of traditional circumcision practices and teachings. One of the main recommendations of this study is that all of the people who are being affected by the traditions in Malawi must work together to search for answers which will protect their health and their culture. Traditional circumcision has survived for many years and has led to the 
spread of AIDS throughout the country and to division among the SDA church, and these harmful results can only be avoided by continually searching for cultural, biblical answers to this issue. 


\section{APPENDIX \\ CIRCUMCISION SUBSTITUTES}

1. The SDA pastors could help the members and the local community to devise healthy and biblical methods of addressing the harmful circumcision teachings. One possible method would be for the church to hold a week of celebration after a traditional circumcision has been held in the community. During this week, the circumcised youth would be invited to attend church meetings in which they would be praised for the new stage in life which they have achieved and where they would also receive a biblical viewpoint on the circumcision teachings. Special gifts could be given to the boys as an incentive for them to attend these meetings. The week of celebration could culminate in a Sabbath ceremony which would involve the families and tribal friends of the circumcised boys; this ceremony would expose more community members to the church's teachings about circumcision. Once the boys had completed the week of meetings, they could be encouraged to continue attending the church by offering them adult-type responsibilities in the church. For example, these boys could be "allowed" to function as greeters, ushers, assistants, and other adult positions in the church. Through their activities with the church, the boys could gradually understand and accept the message of the Gospel on their own, which would lead to their baptism. Note that this process should not be 
carried out solely by the SDA church; the pastor and the church members should be willing to cooperate with and involve various community service programs in their efforts to help the people of the community.

2. The local SDA pastors, along with the SDA church members, could arrange traditional circumcisions conducted by the church in a biblical manner. Christian boys in Malawi could attend these ceremonies, which would provide hygienic circumcision and biblical teachings in a manner which still fulfills the cultural needs of the Lomwe and Yao people. The availability of these alternate traditional circumcisions could attract non-Christian boys to the church, especially because of the safer conditions and lack of physical abuse at these ceremonies. These alternative ceremonies could also evangelize the boys' parents and other curious observers.

3. The Field leadership could designate a budget during their year-end committee for expenses incurred by the churches dealing with issues of traditional circumcision. This budget could include an allotment of funds to assist poor families to send their circumcised boys to youth camps. The SDA youth camps in Malawi are very expensive, and many families cannot afford to send their children to these camps unless they receive financial assistance. By providing funds for the circumcised boys to attend SDA youth camps, the Field leadership would be assisting these boys to receive an understanding of biblical substitutes for the circumcision rituals and teachings through their experiences at the camps. 
4. During the time period when circumcision ceremonies take place in Malawi, the Malamulo SDA Hospital, with financial assistance from the Union and Field leadership and the ADRA Aids Control Program, could provide equipment to the people who are performing the traditional circumcisions, along with medical assistants to monitor the surgical operations. Since traditional circumcision is a sensitive issue in Malawi, the medical assistants should be men who have already been circumcised in the traditional manner, because they would be accepted by the communities.

5. The SDA Union in Malawi could request Malamulo Hospital to provide inexpensive rates for families who may wish to have their children circumcised in the hospital rather than in the traditional manner. The reduced cost would motivate families to weigh the cost of a professional circumcision versus the potential risk of physiological damage and AIDS transmission through traditional circumcision.

6. Some of the Malawian people may not allow their children to be circumcised in hospitals, because this would deprive their children of the traditional teachings which usually accompany circumcisions. In order to protect these people and their families, the Malawian Government Ministry of Health could train the local Lomwe and Yao circumcisers, providing them with the necessary surgical equipment and education for preventing the transmission of AIDS during the circumcision ceremony. 


\section{BIBLIOGRAPHY}

Abdallar, Yohanah. Chikala Cha Wayao (The History of the Yao). Zomba, Malawi: Government Printer, 1919.

"Acts-Ephesians." SDA Bible Commentary. Edited by F. D. Nichol. Washington, DC: Review and Herald Pub. Assn., 1976. 6:493.

Ahmad, Amtiaz. Rituals and Religion Among Muslim in India. New Delhi, India: Ramesh Jain, 1981.

AIDS Secretariat. Malawi AIDS Control Program. Lilongwe, Malawi: Author, 1992.

American Red Cross. Health and Safety Instructor News. Detroit, MI: Chapter of the American Red Cross, 1994.

Annard, K., and P. Hickey. "Pain and its Effects in the Human Neonate and Fetus." New England Journal of Medicine 317 (1987): 1326.

Asheri, Michael. Living Jewish. New York: Everest House, 1978.

Barnes, Albert. Notes on the New Testament. Grand Rapids, MI: Baker Book House, 1953.

Barnes, Sandra T. Africa's Ogun. Bloomington: Indiana University Press, 1989.

Barrett, David B. "Malawi." World Christian Encyclopedia. Nairobi, Kenya: Oxford University Press, 1982.

Barton, George Aaran. Semitic and Hamitic Origins. Philadelphia: University of Pennsylvania Press, 1934.

Beasley-Murray, George R. Baptism in the New Testament. London: McMillan, 1962.

Beidelman, T. The Encyclopedia of Religion. New York: MacMillan Pub., 1987. 3:511. 
Berkhof, Louis. Systematic Theology. Grand Rapids, MI: William B. Eerdmans Pub. Co., 1953.

Best, Earnest. The Letter of Paul to the Romans. Cambridge: Cambridge University Press, 1967.

Bilima, Jaspine D. C. "James Malinki of Malawi: Church Leader in Cross-Cultural Ministry." D.Min dissertation, Andrews University, 1993.

Bloch, Abraham P. The Biblical and Historical Background of Jewish Customs and Ceremonies. New York: Ktav Pub. House, 1980.

Bruce, F. F. Romans. Tyndale New Testament Commentaries. London: InterVarsity Press, 1985.

Campbell, Neil A. Biology. $4^{\text {th }}$ ed. Menlo Park, CA: Benjamin/Cummings Pub. Co., 1996.

Caplan, A. P. "Boys' Circumcision and Girls' Puberty Rites Among the Swahili of Mafia Island, Tanzania." African Journal 46 (1976): 30.

Carson, D. A. New Bible Commentary, 21st Century. Chicago: InterVarsity Press, 1953.

Chikwekwe, Stanley P. M. "Understanding and Dealing with Ancestral Practices in Botswana." D.Min. dissertation, Andrews University, 1997.

Cohen, Eugene J. Guide to Ritual Circumcision and Redemption of the First Born Son. New York: Ktav Pub. House, 1984.

Colman, Warren. Understanding and Preventing AIDS. Chicago: Children's Press, 1988.

Crosby, Cynthia A. Historical Dictionary of Malawi. Metuchen, NJ: Scarecrow Press, 1980.

De Jagar, E. J. Man: Anthropological Essays Presented to O. F. Raum. Cape Town, South Africa: C. Struik (Pty.), 1971.

Debenham, Frank. Nyasaland the Land of the Lake. London: Her Majesty's Stationery Office, 1955.

Denniston, George C. "First, Do No Harm!" Journal of Free Thought and Inquiry 1 (July/August 1989): 36. 
Dictionary of the Later New Testament and Its Developments. Edited by Ralph Martin and Peter H. Davids. Downer's Grove: InterVarsity Press, 1997. S.v. "Circumcision."

Donin, Hayim Halev. To Be a Jew. New York: Basic Books Pub., 1972.

Duff, H. L. Nyasaland Under the Foreign Office. New York: Negro Universities Press, 1969.

Dumbrell, William. Covenant and Creation. Nashville: Thomas Nelson Pub., 1984.

Encyclopedia of the Jewish Religion. Edited by R.J. Zwi Werblowsky and Geoffrey Wigoder. New York: Holt Rinehart and Winston, 1966. S.v. "Circumcision."

Erickson, Millard J. Christian Theology. Grand Rapids, MI: Baker Book House, 1983.

Ewald, H. The Antiquities of Israel. London: Longmans Green, 1896.

"Exodus." SDA Bible Commentary. Edited by F.D. Nichol. Washington, DC: Review and Herald Pub. Assn., 1953-57. 4:29.

Fritsch, Charles T. The Layman's Bible Commentary: Genesis Vol. 2. Atlanta: John Knox Press, 1982.

"Genesis." SDA Bible Commentary. Edited by F.D. Nichol. Washington, DC: Review and Herald Pub. Assn., 1976. 1:323.

Goldman, Ronald. Questioning Circumcision: A Jewish Perspective. Boston: Vanguard Pub., 1998.

- Circumcision: The Hidden Trauma. Boston: Vanguard Pub., 1992.

Government of Malawi and the United Nations in Malawi. Situational Analysis of Poverty in Malawi. Lilongwe, Malawi: Author, 1993.

Greeley, A. The Denomination Society. Glenview, IL: Scott Foresman, 1972.

Hallett, Robin. Africa to 1875: A Modern History. Ann Arbor, MI: University of Michigan Press, 1970.

Harris, Marcus Alred. "A Model for Pastoral Nurture and Care to African-American Persons Who Are HIV Infected or Living with AIDS." D.Min. dissertation, Andrews University, 1995. 
Hiebert, Paul G. Cultural Anthropology. Philadelphia: J. B. Lippincott Co., 1976.

Hoffman, Wendel W., and Stanley Grenz. AIDS Ministry in the Midst of an Epidemic. Grand Rapids, MI: Baker Book House, 1990.

Jacobs, George, and Joseph Kerrin. What We Need to Know About AIDS Now. Woods Hole, MA: Cromlech Books, 1997.

Jemison, Thomas Housel. A Prophet Among You. Boise: Pacific Pub. Assn., 1955.

Jhala, Violet Lucy. "The Shire Highlands: The Establishment and Maintenance of Yao Dominance Under Changing Socio-Economic Circumstances. 1861-1915." Research seminar, Zomba University of Malawi, 1979-80.

Johnston, Harry H. British Central Africa. New York: Negro Universities Press, 1969.

Kalichman, Seth C. Understanding AIDS. Washington, DC: American Psychological Assn., 1995.

Kidner, D. Genesis: An Introduction and Commentary. Chicago: InterVarsity Press, 1968.

Klein, Isaac. A Guide to Jewish Religious Practice. New York: Ktav Pub. House, 1979.

Kline, Meredith G. By Oath Consigned. Grand Rapids, MI: William B. Eerdmans Pub. Co., 1968.

Koester, Beverly Herbrandson. "Seventh-day Adventists Serving Malawi, 1893-1993." Mission, 30 April 1993, 13.

Kraft, Charles H. Christianity in Culture. Maryknoll, NY: Orbis Books, 1979.

Krim, Keith. "Circumcision." Abingdon Dictionary of Living Religion. Nashville: Abingdon Press, 1981. 186.

Lee, James W. Genesis to Joshua. The Self Interpreter's Bible, vol. 1. St. Louis: Thompson Pub. House, 1905.

Lee, Robert E. AIDS in America. New York: Whitson Pub. Co., 1987.

Lewis, Arthur H. "The New Birth under the Old Covenant." Evangelical Quarterly 56 (January 1984): 32. 
Lewis, J. In the Name of Humanity. New York: Eugenies Pub., 1949.

Libman, Howard, and Robert A. Witzburg. HIV Infection: A Clinical Manual. Boston: Little Brown and Co., 1993.

Linden, Ian. Catholics, Peasants, and Chewa Resistance in Nyasaland, 1889-1939. Berkeley: University of California Press, 1974.

Matandiko, Cornelius Mulenga. "A Christian Response to Zambia Death Rituals." D.Min. dissertation, Andrews University, 1996.

McCracken, John. Politics and Christianity in Malawi 1875-1940. London: Cambridge University Press, 1977.

McKitshoff. African Independent Churches. Lewiston, NY: Edwin Mellen Press, 1996.

Minkin, Jacob S. The Teachings of Maimonides. Northvale, NJ: Jason Aronson, 1987.

Mitchell, John J. "Abraham's Understanding of the Lord's Covenant." Westminster Theological Journal 32 (1969): 41.

Morgenstern, J. Rites of Birth, Marriage, Death, and Kindred Occasions Among the Semites. Cincinnati: Hebrew Union College Press, 1966.

Moss, Joyce, and George Willson. People of the World: Africans South of Sahara. Detroit: Gale Research International, 1991.

Murray, Stephen. A Handbook of Nyasaland. London: Crown Agents, 1922.

Namate, Denis F. The Emergence of the Yao as a Political and Economic Force in Mangoche: The Case of Mponda's Area, 1810-1910. Chicago: Northwestern University Library, 1980.

National Geographical Atlas of the World. Edited by William Graves. Washington, DC: National Geographic Society, 1990. S.v. "Malawi."

Neely, Alan. Christian Mission: A Case Study Approach. Maryknoll, NY: Orbis Books, 1995.

Nelson, Harold D. Area Hand Book for Malawi. Washington, DC: American University Press, 1975. 
Netton, Ian Richard. A Popular Dictionary of Islam. Atlantic Highlands, NJ: Humanities Press International, 1992.

Oliver, Roland. The Middle Age of African History. London: Oxford University Press, 1967.

Overberg, Kenneth R. AIDS Ethics and Religion. New York: Orbis Books, 1994.

Oxford Dictionary of the Jewish Religion. Edited by R. J. Zwi Werblowsky and Geoffrey Wigoder. New York: Oxford University Press, 1997. S.v. "Circumcision."

Pachai, Bridglal. The Early History of Malawi. Chicago: Northwestern University Press, 1972. 1973.

Malawi: The History of the Nation. London: Western Printing Services,

Perling, Abraham Isaac S. Reasons for Jewish Customs and Traditions. New York: Block Pub. Co., 1968.

Philo The Works of Philo. Translated by C. D. Yonge. Peabody, MA: Hendrikson Pub., 1993.

Pieters, Albertus. The Seed of Abraham. Grand Rapids, MI: William B. Eerdmans Pub. Co., 1950.

Pollock, Norman H., Jr. Nyasaland and Northern Rhodesia: Corridor to the North. Pittsburgh: Duquese University Press, 1971.

Quackenbush, Marcia, and Pamela Sargent. Teaching AIDS. Santa Cruz, CA: Network Pub., 1986.

Rafael, B. R. A Short History of Malawi. Limbe, Malawi: Popular Pub., 1982.

Ransfold, Oliver. Livingstone's Lake: The Drama of Nyasa, Africa's Inland Sea. New York: Thomas Y. Crowell Co., 1967.

Remondino, P. C. History of Circumcision from the Earliest Times to the Present. Philadelphia: F. A. Davis, 1891.

Renard, John. Seven Doors to Islam. Berkeley, CA: University of California Press, 1996. 
Rigby, Peter. Cattle and Kingship Among the Congo. London: Cornell University Press, 1969.

Ritter, Thomas J., and George C. Denniston. Say No to Circumcision. Aptos, CA: Hourglass Book Pub., 1996.

Roberts, D. S. Islam: A Concise Introduction. New York: Harper and Row, Pub., 1817.

Rowley, H. H. Peake's Commentary on the Bible. Hong Kong: Nelson and Sons, 1962.

Schlosberg, Charles. "Thirty Years of Ritual Circumcision." Clinical Pediatrics 10 (April 1971): 205-209.

Schreiner, Thomas Robert. "Circumcision: An Entree into 'Newness' in Pauline Thought." Ph.D. dissertation, Fuller Theological Seminary, School of Theology, 1983.

Seventh-day Adventist Yearbook. Washington, DC: Review and Herald Pub. Assn., 1998.

Shepperson, George, and Thomas Price. Independent Africa. Edinburgh, Scotland: University Press, 1958.

Shulman, Albert M. "Gateway to Judaism." Encyclopedia Home Reference Vol. 1. New York: Thomas Yoseloff, 1971.

Skjonsberg, Else. Change in an African Village: Kefa Speaks. West Hartford, CT: Kumarian Press, 1989.

Smith, Donald K. Creating Understanding. Grand Rapids, MI: Zondervan, 1992.

Soggin, J. A. Joshua: A Commentary. Philadelphia: Westminster Press, 1972.

Swartz, Marja-Liisa. Ritual and Symbolism in Transitional Zaramo Society. Bocktryckeriaktiebolag, Sweden: Almquist \& Wiksells, 1970.

Tenny, Merrill C. "Circumcision." Zondervan Periodical Encyclopedia of the Bible. Grand Rapids, MI: Zondervan Pub. House, 1975. A-C:866.

Tsoka, Daniel L. The Story of Alomwe. Dublin: Cahil and Co., 1953.

Turnbull, Colin M. Man in Africa. New York: Anchor Press Doubleday, 1976. 
van Gennep, Arnold. The Rites of Passage. Chicago: University of Chicago Press, 1960.

Wangai, Paul. Jr. "The Doctor Says . . ." Eastern Africa Division Outlook. AprilJune 1996, 72.

White, Ellen G. Patriarchs and Prophets. Boise: Pacific Press Assn., 1958.

Whitelaw, T. Acts: The Preacher's Homiletic Commentary. New York: Funk and Wagnall's Co., 1943.

Wigoder, Geoffrey. The Encyclopedia of Judaism. New York: MacMillan Pub. Co., 1989.

Williams, David T. Malawi: The Politics of Despair. London: Cornell University Press, 1978.

Wilson, Geoffrey B. Romans. London: Hazell Watson \& Viney, 1976. 


\section{VITA}

Name: Harry Godfrey Mtike

Place of Birth: Lewis (Makuta) Village, Mbiza, Mulanje, Malawi

Ordination: March 18, 1989, at Ndirande SDA Church, Blantyre, Malawi.

\section{Educational Experience}

1963-1973 Primary School Leaving Certificate -

Satemwa Primary School, Mulanje, Malawi.

Bangwe Catholic Primary School, Blantyre, Malawi.

Misesa Primary School, Blantyre, Malawi.

1977 Malawi School Certificate - Soche Hill Secondary School, Blantyre, Malawi.

1982 Ministerial Diploma - Lake View Seventh-day Adventist Seminary, Mulangeni, Ntcheu District, Malawi.

1987 Bachelor of Arts, Minor in History - Solusi College, Bulawayo, Zimbabwe.

1994 Master of Arts in Pastoral Ministry - Solusi College, Bulawayo, Zimbabwe.

1999 Doctor of Ministry - Andrews University Seventh-day Adventist Theological Seminary, Berrien Springs, Michigan.

\section{Professional Experience}

1977-1981 General Duties Clerk - Import and Export Company of Malawi.

1982-1983 SDA Pastor - Nsanje SDA Church, Nsanje, Malawi.

1987 SDA Pastor - Makande SDA Church, Chikwawa, Malawi.

1988-1989 SDA Pastor - Michiru SDA Church, Blantyre, Malawi.

1989-1990 SDA Church Ministries Director - South Malawi Field, Blantyre, Malawi.

1991-1995 SDA Field President - South Malawi Field, Blantyre, Malawi. 